\title{
Local and Landscape Management of Biological Pest Control in Oil Palm Plantations
}

\section{Dissertation}

For the award of the degree

"Doctor of Philosophy”

of the Georg-August-Universität Göttingen, Faculty of Crop Sciences within the International Ph.D. Program for Agricultural Sciences (IPAG)

Submitted by

Fuad Nurdiansyah, M. PlaHBio

Born in Jambi, Indonesia, on 12 December 1981

Göttingen, March 2016 
1. Supervisor: Prof. Dr. Teja Tscharntke

2. Supervisor: Prof. Dr. Kerstin Wiegand

2. Co-Supervisor: Dr. Yann Clough

Date of Dissertation Submission: 10.03.2016

Date of Oral Examination / Defense: 03.05. 2016 


\section{TABLE OF CONTENTS}

Table of Contents .................................................................................................

Part 1. General Introduction...............................................................................1

Impacts of Oil Palm Expansion ................................................................................

Biodiversity Losses affect Ecosystem Functions ............................................................

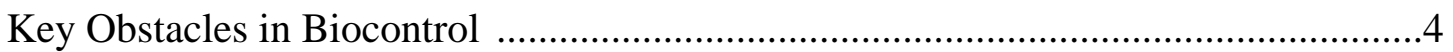

Study Area ...........................................................................................

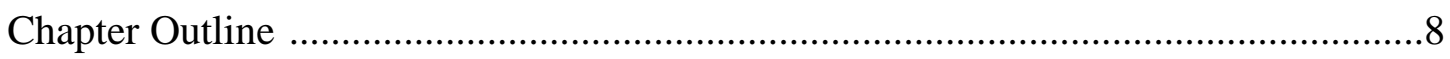

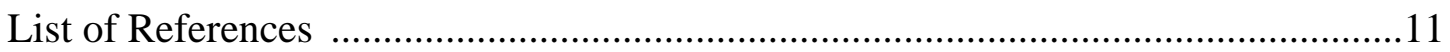

Part 2. Local and Landscape Management Effects on Pests, Diseases, Weeds and Biocontrol in Oil Palm Plantations - A Review ...............14

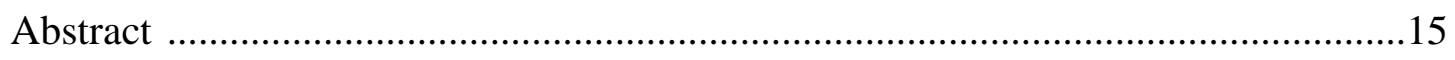

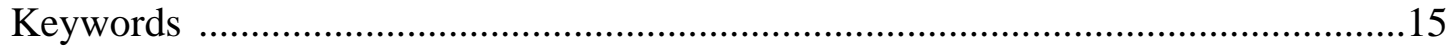

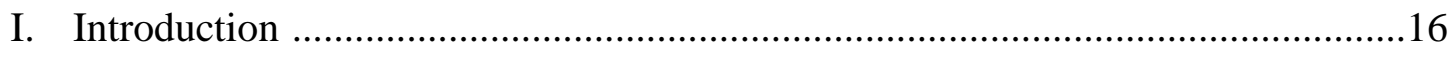

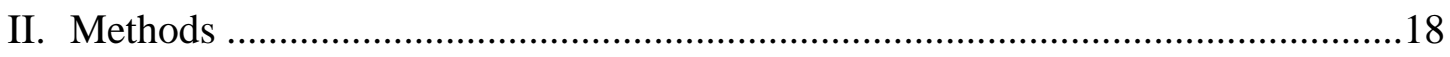

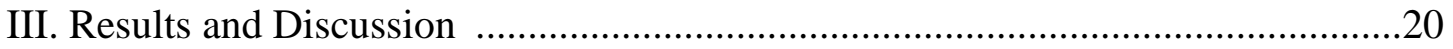

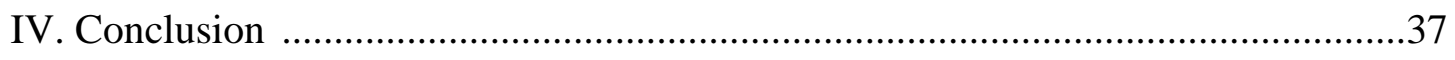

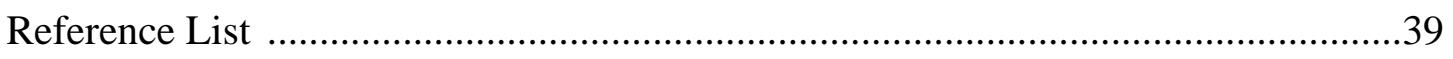

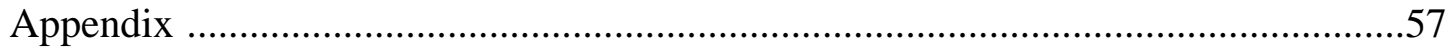

Part 3. Biological Control in Indonesian Oil Palm Potentially enhanced by Landscape Context ..............................................................................................62

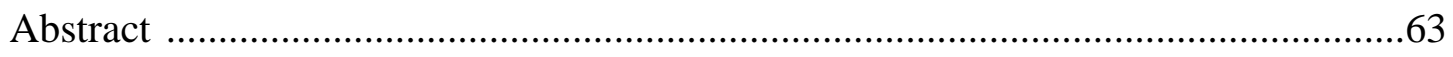

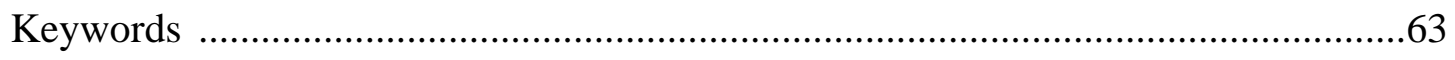

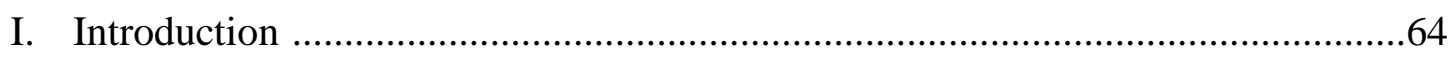

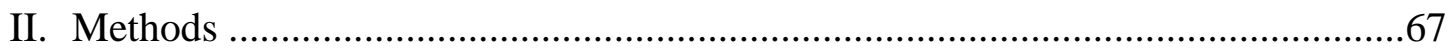

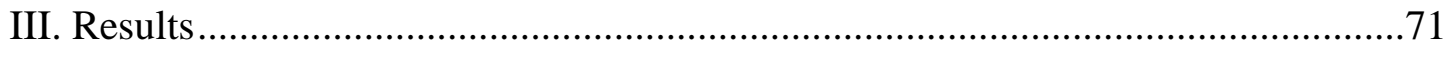




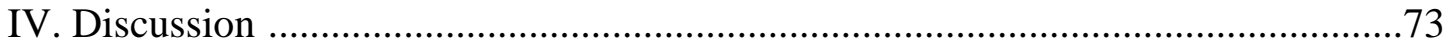

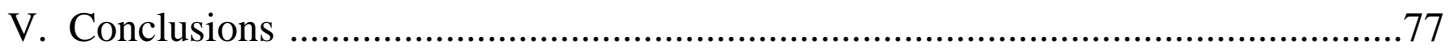

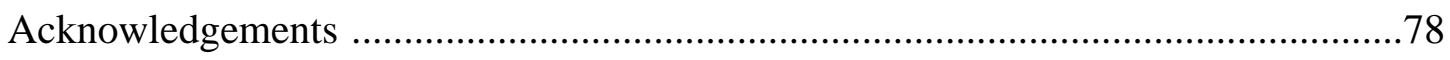

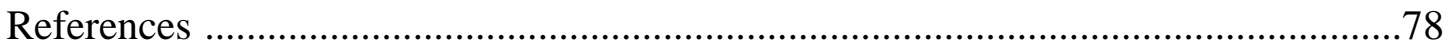

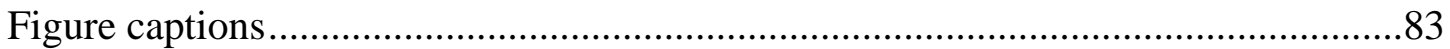

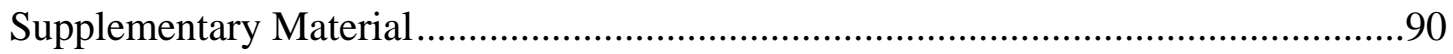

Part 4. Landscape Context of Oil Palm Plantations affects Biocontrol

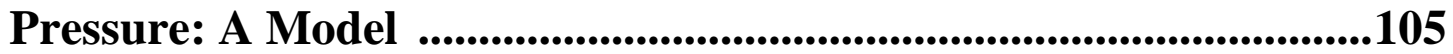

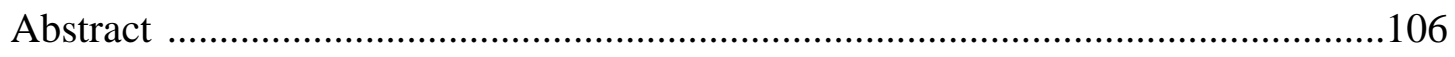

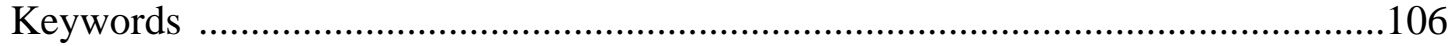

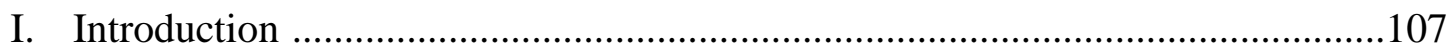

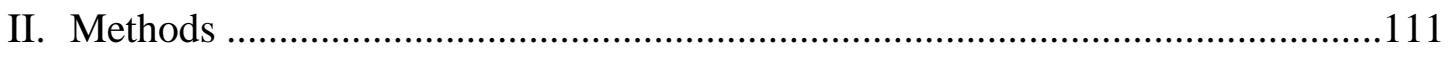

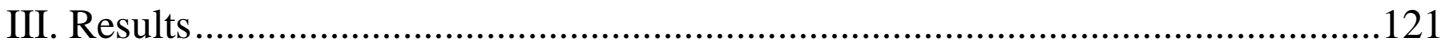

IV. Discussion ...........................................................................................126

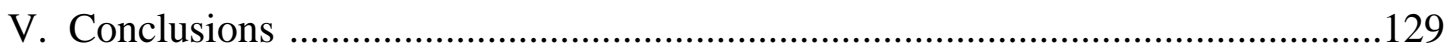

Acknowledgements ..............................................................................................129

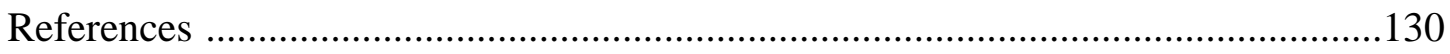

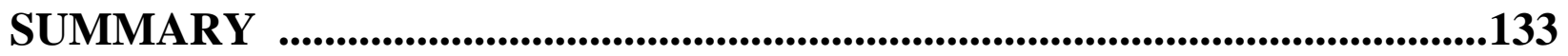

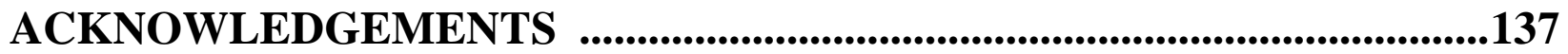

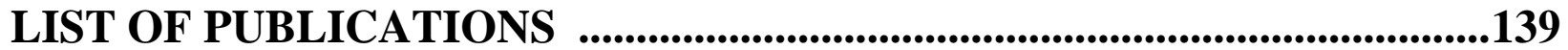

CURRICULUM VITAE .......................................................................................140 


\section{Part 1}

General Introduction 


\section{Impacts of Oil Palm Expansion}

Palm oil is one of the most important agricultural crops used for various goods in the world, from edible to no-edible products (Corley and Tinker, 2008; Murphy, 2009). The main benefits of the crop are its high productivity compared to other oil producing crops (Basiron, 2007; Murphy, 2009; Wahid et al., 2005) and it is a much more economic crop in terms of production input and cost (Carter et al., 2007; Murphy, 2009). Since 2009, Indonesia is the world's chief palm oil producer in the world, accounting for more than half of the world's total palm oil production at around 25,000,000 tons in 2012 (“FAOSTAT,” 2016). The current total plantation areas in Indonesia alone are approximately 10 million hectares and projected to reach 13 million ha by 2020 (Koh, 2011; Rianto et al., 2012).

Great expansion of oil palm plantations transformed from natural habitat (Phalan et al., 2013) results in huge biodiversity losses and alteration of species communities, especially of higher trophic group structures (Chung et al., 2000; Donald, 2004; Fitzherbert et al., 2008). Even though worldwide environmental groups are highly concerned about the adverse effects of the transformation on the global ecosystem (Phalan et al., 2013; Wilcove and Koh, 2010), it seems that the oil palm expansion still continues, leading to even greater expansions in the future (Fitzherbert et al., 2008). The Roundtable on Sustainable Palm Oil (RSPO) certificates is a leading initiative to slow down the deforestation and encourage development of eco-friendly plantations. However, RSPO might fail due to lack of demand for the certificate and low political clout in the biggest importing countries such as China and India (Wilcove and Koh, 2010). Most studies on biodiversity loss due to oil palm generally proposed conservation strategies and mitigation processes which might not have direct economic benefit for the growers (Foster et al., 2011a; Savilaakso et al., 2014a). Investigating the effect of biodiversity loss due to oil palm 
expansion on ecosystem functions such as pest control, pollination, and soil processes might draw the grower's attention via their income if plantation sustainability might be affected by the reduction in ecosystem functioning (Foster et al., 2011a; Savilaakso et al., 2014a). Around the world, lack of empirical evidence for recommendations obstructs many efforts to slow down deforestation and development eco-friendly plantations. In addition, low law enforcement and inexperience of many producers regarding environment concerns often leads to further expansion of oil palm without much consideration of plantation sustainability (McCarthy and Zen, 2010; Obidzinski et al., 2012).

\section{Biodiversity Losses affect Ecosystem Functions}

Similar to other monocultures, oil palm plantations suffer from attacks by insect pests and diseases (Corley and Tinker, 2008; Foster et al., 2011b). Data about their economic importance is still limited (Cooper and Rusli, 2014; Darus and Basri Wahid, 2001; Kamarudin and Wahid, 2010; Kathirithamby et al., 1998; Priwiratama et al., 2014; Ruf, 2000), but severe impacts on yield have been reported. For instances, bagworms (Lepidoptera: Psychidae) can cause 33-50\% yield losses at high infestation levels (Basri et al., 1995, 1988; Kamarudin and Wahid, 2010; Liau, 1987), nettle caterpillars (Lepidoptera: Limacodidae) cause about 30\% yield reduction after the first and second year of infestation respectively (Potineni and Saravanan, 2013), rhinoceros beetles (Oryctes rhinoceros (L.)) reduce yield by about 25\% (Liau and Ahmad, 1991); high abundance of rats destroy around 5 - 10\% of the yield (Wood and Fee, 2003; Wood and Liau, 1978) and the major diseases, Ganoderma boninense, can cause serious economic losses of around 50-80\% of yield (Priwiratama et al., 2014). 
Current management practices have negative impacts on biodiversity that might disturb natural pest and disease regulation (Wood, 2002). Management of monoculture plantations often creates unfavorable condition for biological control agents such as predatory birds, ants, and beetles (Foster et al., 2011a; Senior et al., 2013). Compared to pesticide applications, biological control (short: biocontrol) is known as a sustainable and ecofriendly solution to reduce pest numbers below economic levels by using natural enemies (Hajek, 2004; Norris et al., 2003). In the past, pest outbreak after insecticide application was assumed to be a major cause of imbalance between pest and biocontrol (Wood, 1971). However, despite the decline in use of broad spectrum-long residual contact-insecticides (bslrcs), pest numbers have still continued to reach detrimental numbers in many locations (Kamarudin and Wahid, 2010; Wood, 2002). Thus, the interest in managing plantations to support biodiversity-related ecosystem functions such as biocontrol is increasing (Foster et al., 2011b; Murphy, 2009, 2007). A hurdle for scientists and practitioners is the lack of available evidence for the effectiveness of different strategies.

\section{Key Obstacles in Biocontrol}

Defoliating pests, in particular bagworms (Psychidae) and nettle caterpillars (Limacodidae), play the most important roles in reducing crop yield due to their high reproduction and mobility (Wood, 2002). Significant pest attacks can be related to an imbalance between pests and their natural enemies (Igbinosa, 1992; Wood, 2002). Studies on the biocontrol of pests have mostly focused on the introduction of exotic biocontrol agents to the field or on the assessment of potential agents (Bakeri et al., 2009; Kamarudin and Wahid, 2010; Zeddam et al., 2003), rather than on evaluating factors influencing native enemy populations. There has been no 
comprehensive study that links pests to native biocontrol agents in oil palm plantations (Foster et al., 2011a; Savilaakso et al., 2014b).

There is a lack of direct investigations of the relative importance of landscape management on biocontrol (Foster et al., 2011a; Savilaakso et al., 2014a). Landscape management may enhance the search rate of insect predators (i.e. the rate at which the predator encounters prey) by facilitating close contact of the predator with the prey. Landscape management will also reduce predator starvation because the surrounding vegetation gives another option for food resources for predators when the prey is on the wane (Bianchi et al., 2006; Tscharntke et al., 2007). A potential method for increasing biodiversity in the plantations, and in particular for increasing native biocontrol agents, is the increase of landscape heterogeneity through approaches such as protection of riparian buffers (Gray and Lewis, 2014), leaving patches of natural forest and agroforestry within the landscape, and enhancing the understorey vegetation (Koh, 2008; Koh et al., 2009).

Limited findings recognized that biodiversity loss due to the conversion to oil palm threatens a biodiversity-related ecosystem function, biocontrol. Chung et al, 2000 report that land-use change reduced predatory beetle abundance and richness by about 50\% and 23\% respectively (Chung et al., 2000). The lower predatory ant composition in the plantation compared to natural habitat may have resulted in considerable pest attacks in the plantations; Denmead et al. in prep.). Increasing landscape complexity and connectivity among habitats may provide a way to manipulate biological control in agroecosystems (Tscharntke et al., 2012, 2007). However, research on factors influencing biocontrol agents in oil palm plantations, such as landscape context or local management, is lacking. Yet, such research is urgently needed to 
understand the potential for biocontrol conservation methods in order to stop yield losses from pest attacks.

Understanding the potential contributions of local practices and landscape-scale management on biodiversity related ecosystem function, especially biocontrol, is important for developing sustainable strategies for the management of pests and diseases in oil palm plantations. Thus, in this thesis, I focus on the following objectives:

1. Literature review of oil palm pests, diseases, and biological control agents and the importance of local and landscape management on the relationship between these organisms - Chapter 2

2. Field research on the effect of landscape context of oil palm plantations and the influence of the distance to the plantation border on predator predation rates - Chapter 3

3. Modeling predation pressure in plantations under different types of plantation borders, plantation sizes and shapes - Chapter 4

4. Potential recommendations for sustainable management of oil palm pests and diseases through biocontrol - All Chapters 


\section{Study Area}

Field research was carried out for Chapter 3, "Biological Control in Oil Palm enhanced by Landscape Context”. The study was conducted within two regions in the Batanghari and Sarolangun Regencies in Jambi Province, Sumatra, Indonesia. Both study regions were located in the lowland area of the province with potential vegetation of tropical lowland rainforest (citation). However, recently the area cultivated as oil palm plantations increased from 150,000 ha to 550,000 ha in the period from 1996 to 2011 (Gatto et al. 2014), making oil palm one of the most dominant crops in the province.
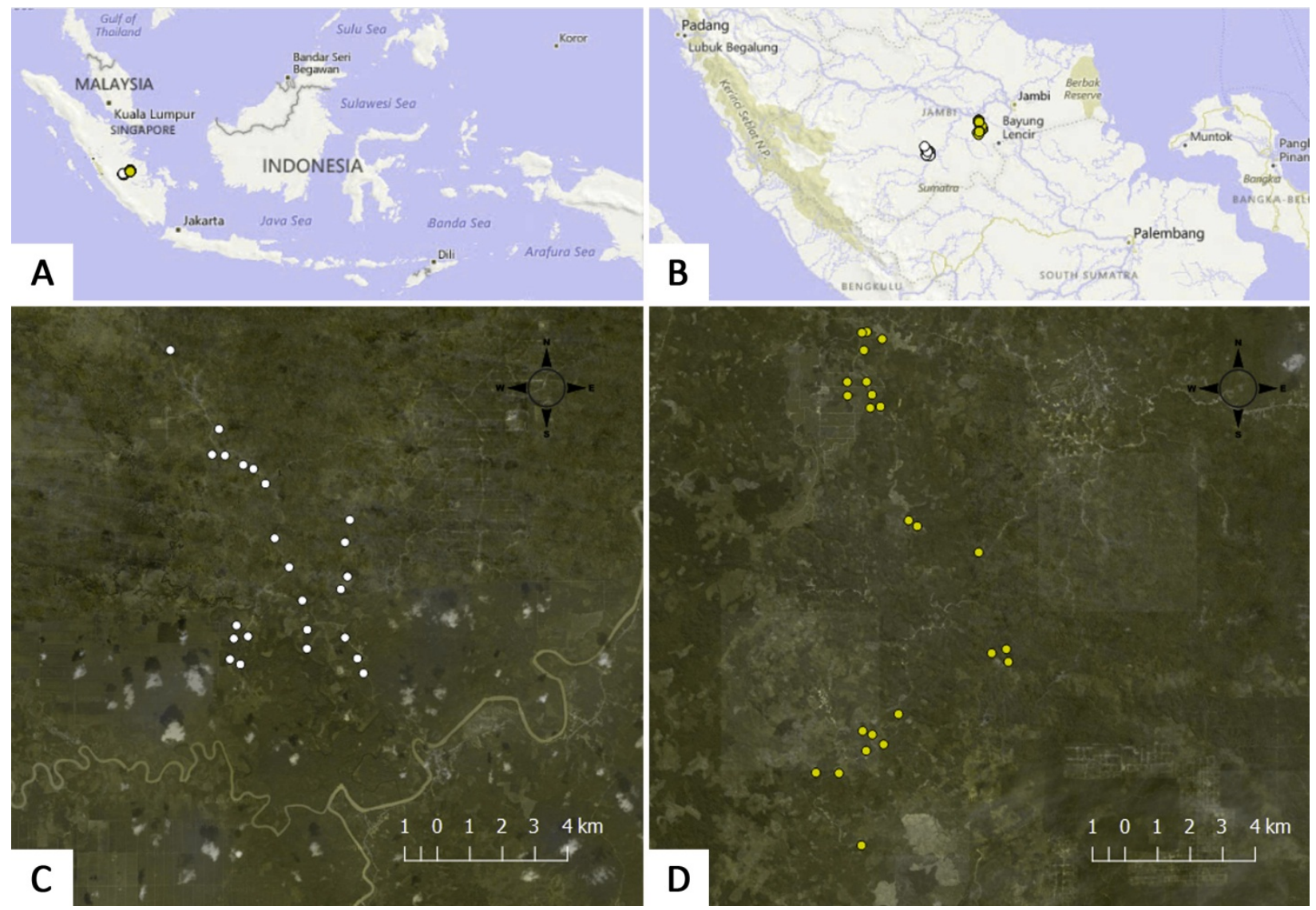

Figure 1. Map of study area in Chapter 3 located in the Sarolangun (C) and Batanghari (D) regencies in Jambi Province (B), Sumatra, Indonesia (A). 


\section{Chapter Outline}

Chapter 2 - We investigated factors that are hypothesized to influence the occurrence of pests, diseases, and biocontrol agents in oil palm plantations grouped as follows: pesticides usages, fertilizer applications, vegetation surrounding oil palm plantations, and oil palm understory. We systematically reviewed the literature using the ISI Web of Science, Ebscohost and Google Scholar. We present a review of the pests, diseases, and biocontrol agents, the influencing managements and potential recommendations for developing sustainable pest and disease management through biocontrol. Among all studies on pests, diseases, and biocontrol agents, trunk borer pests, defoliator pests, and the wilt diseases are the most studied organisms in oil palm. The number of biocontrol studies is in line with the number of studies on pests and disease organisms. Although these studies show that the biocontrol agents applied could effectively and efficiently regulate the pests and diseases, most of these measures seem impracticable for application in big plantation areas due to affordability and also sustainability of the controls. There is no direct study of the effect of local and landscape managements, but some implicit information can be used to assess the importance of the managements. Pesticide usages Common pesticide applications tend to produce problems such as damage on non-target organisms and pests resistances. Fertilizer applications - Several macro and micro nutrients can significantly increase or decrease the incidence of diseases, depending on the type of soil. Vegetation surrounding - The effects of vegetation surrounding oil palm plantations on pests, diseases, and biocontrol agents have not been studied yet. The land conversion to oil palm reduces insectivorous birds and favors herbivorous over predatory beetles, which can lead to significant increases of pest attacks in oil palm plantations. Oil palm understory - the vegetation habitats have a positive influence, but more likely if specific flowering plants, e.g. 
Cassia cobanensis and Asystasia gangetica and suitable flora, Nephrolepsis biserrata, Pueraria phaseoloides, Calopogonium caeruleum and Arachis pintoi are grown to protect the crop from pests and disease or as food sources for biocontrol agents. Overall, we conclude there is a lack of research how pests, diseases and biocontrol are determined by local management. We recommend a broader perspective, considering also landscape management and its potential for biocontrol conservation in future studies.

Chapter 3 - We investigated the effect of vegetation surrounding oil palm plantations on pest predation rate. We studied six different vegetation types adjacent to oil palm plantations: another oil palm plantation (control), weedy oil palm, weedy rubber, scrub, jungle rubber, and secondary forest. Each border type was replicated eight times. We quantified predation rates and predator occurrences using dummy caterpillars and mealworms $20 \mathrm{~m}$ from the border inside the adjacent vegetation and $20 \mathrm{~m}$ as well as $50 \mathrm{~m}$ inside the oil palm plantation. We found ants and bush crickets were the most prominent predators in the plantations, whereas birds, bats, monkeys, beetles, and molluscs played a minor role. Predation rates were $\sim 70 \%$ higher in non-oil palm habitat. This effect spilled over into the focal plantations, where predation rates were increased by $55-100 \%$ at a distance of $20 \mathrm{~m}$ from the border and $40-55 \%$ at a distance of $50 \mathrm{~m}$ from the border. Overall predation rates in oil palm decreased slightly but significantly with distance to the border. This indicates the need to improve vegetation diversification of plantations. Our results suggest that oil palm management maintaining non-oil palm vegetation in the neighbourhood and weedy plant strips inside the plantation may be most promising for effective conservation biological control in the future. 
Chapter 4 - We investigate the effect of landscape context by simulating three different landscape-driven factors on predation pressure: border type, plantation size and shape. Based on field data from Chapter 3, data analysis using linear regression was performed and an agentbased model was developed to address two specific objectives: 1). Investigating the effects of the landscape context on the predation pressure inside the plantation, 2). Evaluating strategies of sustainable pest control via oil palm landscape management. Model results showed that landscape complexity was the major influence on the predation pressure. Under complex arrangements of vegetation surrounding the oil palm plantation, predation pressure inside the plantation might even double. Increasing plantation size led to considerable decrease in predation pressure by up to $50 \%$, while narrowing the plantation compensated predation pressure by about $20 \%$. The effect of landscape context which potentially increased the pressure were only limited in the plantation sizes between $50-100$ ha, suggesting higher potential pest attacks in the plantation higher than the sizes. Thus, a good strategy for sustainable pest control in the plantation might be to retain higher vegetation surrounding the plantation, to develop small and narrow plantations in order to have high predation pressure. Further studies on growing weedyflowering plants as crop understory might help to distribute and increase the pest pressure inside relatively bigger plantations. 


\section{List of References}

Bakeri, S.A., Ali, S.R.A., Tajuddin, N.S., Kamaruzzaman, N.E., 2009. Efficacy of entomopathogenic fungi, Paecilomyces spp., in controlling the oil palm bagworm, Pteroma pendula (Joannis). J. Oil Palm Res. 21, 693-699.

Basiron, Y., 2007. Palm oil production through sustainable plantations. Eur. J. Lipid Sci. Technol. 109, 289-295. doi:10.1002/ejlt.200600223

Basri, M.W., Abdul Halim, H, Zulkipli M., 1988. Bagworms (Lepidoptera: Psychidae) of Oil Palms in Malaysia. PORIM Occas. Pap. 23, : 1-23.

Basri, M.W., Norman, K., Hamdan, A.B., 1995. Natural enemies of the bagworm, Metisa plana Walker (Lepidoptera: Psychidae) and their impact on host population regulation. Crop Prot. 14, 637-645. doi:10.1016/0261-2194(95)00053-4

Bianchi, F.J.J.,, Booij, C.J.., Tscharntke, T., 2006. Sustainable pest regulation in agricultural landscapes: a review on landscape composition, biodiversity and natural pest control. Proc. R. Soc. B Biol. Sci. 273, 1715-1727. doi:10.1098/rspb.2006.3530

Carter, C., Finley, W., Fry, J., Jackson, D., Willis, L., 2007. Palm oil markets and future supply. Eur. J. Lipid Sci. Technol. 109, 307-314. doi:10.1002/ejlt.200600256

Chung, A.Y.C., Eggleton, P., Speight, M.R., Hammond, P.M., Chey, V.K., 2000. The diversity of beetle assemblages in different habitat types in Sabah, Malaysia. Bull. Entomol. Res. 90, 475-496.

Cooper, R.M., Rusli, M.H., 2014. Threat from Fusarium Wilt Disease of Oil Palm to South-East Asia and Suggested Control Measures. J. Oil Palm Res. 26, 109-119.

Corley, R.H.V., Tinker, P.B.H., 2008. The Oil Palm. John Wiley \& Sons.

Darus, A., Basri Wahid, M., 2001. Intensive IPM for management of Oil Palm Pests. Malays. Palm Oil Board Kuala Lumpur Malays. 41.

Denmead Lisa H., Bernhard Klarner, Ingo Grass, Yann Clough, Valentyna Krashevska, Widria Liza, Akhmad Rizali, Stefan Scheu, Rahayu Widyastuti, Teja Tscharntke, Ants affect belowground invertebrate communities and associated ecosystem processes across tropical land-use systems (in prep.)

Donald, P.F., 2004. Biodiversity impacts of some agricultural commodity production systems. Conserv. Biol. 18, 17-37. doi:10.1111/j.1523-1739.2004.01803.x

FAOSTAT [WWW Document], 2016. URL http://faostat.fao.org/site/339/default.aspx (accessed 2.15.16).

Fitzherbert, E., Struebig, M., Morel, A., Danielsen, F., Bruhl, C., Donald, P., Phalan, B., 2008. How will oil palm expansion affect biodiversity? Trends Ecol. Evol. 23, 538-545. doi:10.1016/j.tree.2008.06.012

Foster, W.A., Snaddon, J.L., Turner, E.C., Fayle, T.M., Cockerill, T.D., Ellwood, M.D.F., Broad, G.R., Chung, A.Y.C., Eggleton, P., Khen, C.V., Yusah, K.M., 2011a. Establishing the evidence base for maintaining biodiversity and ecosystem function in the oil palm landscapes of South East Asia. Philos. Trans. R. Soc. B Biol. Sci. 366, 3277-3291. doi:10.1098/rstb.2011.0041

Foster, W.A., Snaddon, J.L., Turner, E.C., Fayle, T.M., Cockerill, T.D., Ellwood, M.D.F., Broad, G.R., Chung, A.Y.C., Eggleton, P., Khen, C.V., Yusah, K.M., 2011b. Establishing the evidence base for maintaining biodiversity and ecosystem function in the oil palm landscapes of South East Asia. Philos. Trans. R. Soc. B Biol. Sci. 366, 3277-3291. doi:10.1098/rstb.2011.0041 
Gray, C.L., Lewis, O.T., 2014. Do riparian forest fragments provide ecosystem services or disservices in surrounding oil palm plantations? Basic Appl. Ecol. 15, 693-700. doi:10.1016/j.baae.2014.09.009

Hajek, A.E., 2004. Natural Enemies: An Introduction to Biological Control. Cambridge University Press.

Kamarudin, N., Wahid, M.B., 2010. Interactions of the bagworm, Pteroma pendula (Lepidoptera: Psychidae), and its natural enemies in an oil palm plantation in Perak. J. Oil Palm Res. 22, 758-764.

Kathirithamby, J., Simpson, S., Solulu, T., Caudwell, R., 1998. Strepsiptera parasites - novel biocontrol tools for oil palm integrated pest management in Papua New Guinea (vol 44, pg 127, 1998). Int. J. Pest Manag. 44, 261-+.

Koh, L.P., 2011. Balancing societies’ priorities: An ecologist's perspective on sustainable development. Basic Appl. Ecol. 12, 389-393. doi:10.1016/j.baae.2011.05.004

Koh, L.P., 2008. Birds defend oil palms from herbivorous insects. Ecol. Appl. 18, 821-825. doi:10.1890/07-1650.1

Koh, L.P., Levang, P., Ghazoul, J., 2009. Designer landscapes for sustainable biofuels. Trends Ecol. Evol. 24, 431-438. doi:10.1016/j.tree.2009.03.012

Liau, S.S., 1987. Problems and control of bagworms (Lepidoptera: Psychidae) and rats (Rodentia: Muridae) in the oil palm, in: Proceedings of the Second Chemara Workshop. pp. 46-59.

Liau, S.S., Ahmad, A., 1991. The control of Oryctes rhinoceros by clean clearing and its effect on early yield in palm to palm replants, in: Proceedings of the 1991 PORIM International Palm Oil Development Conference-Module II (Agriculture).

McCarthy, J., Zen, Z., 2010. Regulating the Oil Palm Boom: Assessing the Effectiveness of Environmental Governance Approaches to Agro-industrial Pollution in Indonesia. Law Policy 32, 153-179.

Murphy, D.J., 2009. Oil palm: future prospects for yield and quality improvements. Lipid Technol. 21, 257-260. doi:10.1002/lite.200900067

Murphy, D.J., 2007. Future prospects for oil palm in the 21(st) century: Biological and related challenges. Eur. J. Lipid Sci. Technol. 109, 296-306. doi:10.1002/ejlt.200600229

Norris, R.F., Caswell-Chen, E.P., Kogan, M., 2003. Concepts in Integrated Pest Management. Prentice Hall.

Obidzinski, K., Andriani, R., Komarudin, H., Andrianto, A., 2012. Environmental and Social Impacts of Oil Palm Plantations and their Implications for Biofuel Production in Indonesia. Ecol. Soc. 17. doi:10.5751/ES-04775-170125

Phalan, B., Bertzky, M., Butchart, S.H.M., Donald, P.F., Scharlemann, J.P.W., Stattersfield, A.J., Balmford, A., 2013. Crop Expansion and Conservation Priorities in Tropical Countries. PLoS ONE 8, e51759. doi:10.1371/journal.pone.0051759

Potineni, K., Saravanan, L., 2013. Natural enemies of oil palm defoliators and their impact on pest population. Pest Manag. Hortic. Ecosyst. 19, 179-184.

Priwiratama, H., Susanto, A., others, 2014. Utilization of fungi for the biological control of insect pests and Ganoderma disease in the Indonesian oil palm industry. J. Agric. Sci. Technol. A 4, 103-111.

Rianto, B., Mochtar, H., Sasmito, A., 2012. Overview of palm oil Industry landscape in Indonesia. PT Prima Wahana Caraka PwC Indones. 1-12. 
Ruf, F., 2000. Socioeconomic factors modulating plantation replanting. Ocl-Ol. Corps Gras Lipides 7, 189-196.

Savilaakso, S., Garcia, C., Garcia-Ulloa, J., Ghazoul, J., Groom, M., Guariguata, M.R., Laumonier, Y., Nasi, R., Petrokofsky, G., Snaddon, J., Zrust, M., 2014a. Systematic review of effects on biodiversity from oil palm production. Environ. Evid. 3, 1-21. doi:10.1186/2047-2382-3-4

Savilaakso, S., Garcia, C., Garcia-Ulloa, J., Ghazoul, J., Groom, M., Guariguata, M.R., Laumonier, Y., Nasi, R., Petrokofsky, G., Snaddon, J., Zrust, M., 2014b. Systematic review of effects on biodiversity from oil palm production. Environ. Evid. 3, 4. doi:10.1186/2047-2382-3-4

Tscharntke, T., Bommarco, R., Clough, Y., Crist, T.O., Kleijn, D., Rand, T.A., Tylianakis, J.M., van Nouhuys, S., Vidal, S., 2007. Conservation biological control and enemy diversity on a landscape scale. Biol. Control 43, 294-309. doi:10.1016/j.biocontrol.2007.08.006

Tscharntke, T., Tylianakis, J.M., Rand, T.A., Didham, R.K., Fahrig, L., Batáry, P., Bengtsson, J., Clough, Y., Crist, T.O., Dormann, C.F., Ewers, R.M., Fründ, J., Holt, R.D., Holzschuh, A., Klein, A.M., Kleijn, D., Kremen, C., Landis, D.A., Laurance, W., Lindenmayer, D., Scherber, C., Sodhi, N., Steffan-Dewenter, I., Thies, C., van der Putten, W.H., Westphal, C., 2012. Landscape moderation of biodiversity patterns and processes - eight hypotheses. Biol. Rev. 87, 661-685. doi:10.1111/j.1469-185X.2011.00216.x

Wahid, M.B., Nor Akmar Abdullah, S., E. Henson, I., 2005. Oil Palm-Achievements and Potential. Plant Prod. Sci. 8, 288-297.

Wilcove, D.S., Koh, L.P., 2010. Addressing the threats to biodiversity from oil-palm agriculture. Biodivers. Conserv. 19, 999-1007. doi:10.1007/s10531-009-9760-x

Wood, B.J., 2002. Pest control in Malaysia's perennial crops: a half century perspective tracking the pathway to integrated pest management. Integr. Pest Manag. Rev. 7, 173-190.

Wood, B.J., Fee, C.G., 2003. A critical review of the development of rat control in Malaysian agriculture since the 1960s. Crop Prot. 22, 445-461. doi:10.1016/S0261-2194(02)002077

Wood, B.J., Liau, S.S., 1978. Rats as agricultural pests in Malaysia and the tropics. The Planter $54,580-599$.

Zeddam, J.L., Cruzado, J.A., Rodriguez, J.L., Ravallec, M., 2003. A new nucleopolyhedrovirus from the oil-palm leaf-eater Euprosterna elaeasa (Lepidoptera : Limacodidae): preliminary characterization and field assessment in Peruvian plantation. Agric. Ecosyst. Environ. 96, 69-75. doi:10.1016/S0167-8809(03)00034-3 


\section{Local and Landscape Management Effects on Pests, Diseases, Weeds and Biocontrol in Oil Palm Plantations - A Review}

Fuad Nurdiansyah, Yann Clough, Kerstin Wiegand, and Teja Tscharntke 


\begin{abstract}
Sustainable biocontrol of oil palm pests and diseases requires understanding of both local and landscape managements. Factors that are hypothesized to influence the occurrence of pests, diseases and biocontrol organisms in plantations can be grouped as follows: pesticide usages, fertilizer applications, vegetation surrounding oil palm plantations, and oil palm understory. However, there is no synthesis of the evidence for the effectiveness of different management strategies. Here we present a systematic review of the pests, diseases and biocontrol agents of oil palm, the influential management strategies and provide potential recommendations for developing sustainable pest and disease management through biocontrol. We found the trunk borer pests, defoliators pests and the wilt diseases are the most studied organisms in oil palm, while the number of biocontrol studies is in line with the number of studies on pests and disease organisms. Although biocontrol could effectively and efficiently regulate the pests and diseases, most of them seem impracticable to be applied in big plantation areas due to affordability and also sustainability of the controls. There is no study explicitly analyzing the relative role of local and landscape management, wile some information can be used from what is published so far. For example, pesticide aplications tend to produce problems such as damage on non-target organisms; and pest and weed resistances. Systemic insecticides show irregular results in terms of effectiveness and efficiency of pest control. Fertilizer applications can increase or decrease the incidence of diseases, depending on the type of soil. Fertilizer applications accompanied with burying oil-palm waste as compost around oil palms together with Trichoderma spp., appears to be the best method for promoting biocontrol of diseases. Studies on the vegetation surrounding oil palm plantations focused only on butterflies and wild pigs, whereas effects on pests, diseases, and biocontrol organisms have not been studied yet. In general, the conversion of forest to oil palm plantations reduces numbers of insectivorous birds and favors herbivorous over predatory beetles, which may lead to significant increases of pest attacks in oil palm plantations. Oil palm understory vegetation can have a positive influence on biological pest control. Weedy or flowering plants such as Cassia cobanensis, Asystasia gangetica, Nephrolepsis biserrata, Pueraria phaseoloides, Calopogonium caeruleum and Arachis pintoi can protect the crop from pest and disease problems and can be food sources for biocontrol agents. We conclude that there is a lack of research on a broader spatical scale, considering local farm and large-scale landscape management and its apparent potential for identifying the drivers of pest, disease and weed incidence as well as conservation biological control.
\end{abstract}

\title{
Keywords
}

Biological Control, Integrated Management, Sustainable, Conservation, Eco-friendly Plantation 


\section{Introduction}

Oil palm is one of the most important agricultural crops worldwide (Corley and Tinker, 2008; Murphy, 2009). The main benefit of oil palm compared with other oil producing crops is its high productivity (Carter et al., 2007; Murphy, 2009). However, the yield can vary strongly, not only due to differences in variety and agronomic management, but also due to crop losses from pest and disease attacks (Corley and Tinker, 2008; Gitau et al., 2009; Murphy, 2007). Data about the economic importance of these losses is still limited (Cooper and Rusli, 2014; Darus and Basri Wahid, 2001; Kamarudin and Wahid, 2010), but severe impacts on yield have been reported. For instance, bagworms (Lepidoptera: Psychidae) can cause 33-50\% yield loss at high infestation levels (Basri et al., 1995, 1988; Kamarudin and Wahid, 2010; Liau, 1987), nettle caterpillars (Lepidoptera: Limacodidae) cause about 30\% yield reduction in the first two year of infestation (Potineni and Saravanan, 2013), rhinoceros beetles (Oryctes rhinoceros (L.)) reduce yield by about 25\% (Liau and Ahmad, 1991); high abundance of rats destroys around 5 - 10\% of the yield (Wood and Fee, 2003; Wood and Liau, 1978), and the major disease, Ganoderma boninense, can cause serious economic losses of around 50-80\% of yield (Priwiratama et al., 2014).

Current management in oil palm plantations makes heavy use of agrochemicals with negative impacts on biodiversity that might adversely affect natural pest and disease regulation (Norris et al., 2003; Tscharntke et al., 2007; Wood, 2002). In young plantations (i.e., crop age of up to 10 years), plantation floor is often overgrown by leguminous ground covers such as Pueraria phaseoloides, Mucuna cochinchinensis, Centrosema pubescens, Calopogonium mucunoides, and Calapogonium caeruleum (Corley and Tinker, 2008; Fairhurst and McLaughlin, 2009; Koh, 2008a). However, as the oil palms are getting bigger and produce shade, the legumes cannot grow properly and are replaced by weedy plants (Corley and Tinker, 2008). Herbicides are then intensively applied in order to manage the weedy plants, normally three to four times a 
year, which results in bare ground in the plantation (Fairhurst and McLaughlin, 2009; Koh, 2008a), with negative effects on biodiversity. At the landscape scale, habitat diversity may provide alternative resources for biocontrol agents of pests and diseases that are not found in oil palm plantations (Bianchi et al., 2006; Norris et al., 2003; Tscharntke et al., 2007). However, as the area of oil palm cultivation expands, habitat diversity can be expected to decrease and to incur increasing problems with pests and diseases (Basiron, 2007; Koh, 2008b; Wood, 2002). In this case, the interest in managing plantations to support biodiversity-related ecosystem functions such as biocontrol should be increasing (Foster et al., 2011; Savilaakso et al., 2014).

Understanding the potential contributions of local management (phytosanitary and cultural) and landscape-scale management (e.g. providing refugia for natural enemies) is important for developing sustainable strategies for the control of oil palm pests and diseases (Foster et al., 2011; Koh, 2008b). A hurdle for scientists and practitioners is the lack of an available synthesis of the evidence for the effectiveness of different management strategies. Here, we close this gap by systematically reviewing the empirical evidence so far. We focus on the following questions: 1) Which kinds of oil palm pests, diseases, and biocontrol have been studied? 2) Are populations of pests, diseases, and biocontrol agents in oil palm plantations affected by pesticides usage, fertilizer applications, the surrounding vegetation, and the oil palm understory? (3) How does the surrounding vegetation interact with local management practices? 4) How can oil palm managers sustainably manage oil palm pests and diseases? Through a systematic literature search and review in the ISI Web of Science, Ebscohost and Google Scholar, we gathered information about the field situation in oil palm plantations worldwide. 


\section{Methods}

A systematic search of the literature was carried out on the ISI Web of Science (WOS), Ebscohost, and Google Scholar. The literature search process has been divided into two parts. Part one, starting by searching very broadly for studied topics on pests, diseases, and biocontrol agents in oil palm, and Part two, searching directly for effects of both local and landscape managements (Figure 1). In the part one, our goal was to determine which topics, i.e. what kinds of oil palm pests, diseases, and biocontrol agents, have been studied. The literature was assessed by screening the titles and abstracts, and if this did not show clear results, the full text was screened. Papers that only measured the efficacy of pest, disease, and biocontrol rather than the effect of the management on these topics were excluded from the database. After paper selection, we checked the full text as well as their references to collect more detailed information about the effect of the managements on pests, disease, and biocontrols. Effects of pesticide usages and fertilizer application were categorized as the local management effects, while the effects of landscape management were observed on effects of the conversion, surrounding vegetation, distance (proximity) to adjacent, and oil palm understory. Due to low number of study on the direct effects of the managements, the term of pests, disease and biocontrol were excluded from search term database in order to include more species and studies. From the articles found, we constructed search keywords and created a repeatable search term string in order to find more studies relevant to our objectives. Then, we followed the cited references to gather more of the targeted information. The search terms were applied to WOS in March 2013 - January 2015, while we searched the cited references in several search engines namely WOS, Ebscohost and Google Scholar. 


\section{Part One}

Goal: list information of oil palm pests, diseases, and biocontrol including their studied topics

\section{Part Two}

Goal: list information of the effects of oil palm surroundings, understorey, pesticide and fertilizer on oil palm pests, diseases, and biocontrols
Generate general search terms for

oil palm pests, diseases, and biocontrols

Result: the terms (appendix 1)

Apply the terms in Web of Science (WOS)

Process: March 2013 - January 2015

Find studied topics of the organisms

from all titles and abstracts of the articles found Result: list of the topics studied (appendix 2)

Find terms on the effects of local and

(4) landscape management from the articles from part one by its titles, abstracts and full text.

Result: searchable terms (appendix 1)

Construct repeatable search terms and

applied to WOS

Result: only few concerned articles found

Constract the search terms of the effect of local and landscape management on general organisms

6 rather than specific only on oil palm pests, diseases, or biocontrols

Result: more articles found

Repeat process of finding cited references from the article collection, not only in WOS,

but also from Ebscohost and Google Scholar. Result: more articles found

Assess detailed information on the effect

8 of oil palm local and landscape management to organisms from different taxa

Result: detailed information of the management

Figure 1. The literature search process to find targeted information relevant to the systematic review objectives. Part One and Two consist of 3 and 5 steps, respectively. Details are given in main text. 


\section{Results and Discussion}

Searching for papers on oil palm pest, disease, and biocontrol in the WOS (Part One in Fig.1) yielded 186 articles about pests, 925 articles about diseases, and 133 articles about biocontrol. After assessing titles and abstracts and excluding thematically unrelated articles, we had 94, 119 and 46 articles related to these themes, respectively. The second part of the search yielded 20 articles with relevant information that directly or indirectly addressed the effect of both local and landscape management on pests (10 articles), diseases (4 articles), or their biocontrol (6 articles). However, by constructing search terms of the local and landscape management effects without the pests, diseases and biocontrols terms, and by looking up article cited in the articles found above, we recovered 33 articles on plantation surroundings, 25 articles on oil palm understory, 25 articles on pesticide application and 16 articles on fertilizer application. We faced difficulties as some of the articles had been written in a foreign language, categorized as grey literature, or the full text was not accessible for the wider scientific community. The articles with a foreign language were simply excluded from our database, while some information was taken from the abstracts of the restricted articles if suitable. 


\section{A. Studies on pests, diseases and biological control in oil palm}

A variety of oil palm pests, diseases, and biocontrol measures have been studied (Appendix 2). The most studied insect pests in oil palm are trunk borers with the dominant species Rhynchophorus ferrugineus and Oryctes rhinoceros (28 articles). The defoliator species group is also a very common topic in the study area (25 articles), especially nettle caterpillars and bagworms. The diseases most studied in oil palm were wilt diseases, mostly caused by Ganoderma sp (71 articles). In line with research in pests and diseases, most biocontrol studies were about root and trunk borers, defoliators, and wilt diseases. Given this focus of attention, it is likely that these organisms occur often in oil palm plantations and have a high impact on reducing oil palm production. Interestingly, different groups of pests or diseases can be more devastating in some parts of the world than in others (Corley and Tinker, 2008; Turner, 1981; Wood, 1968). Examples include serious defoliation events by several groups of caterpillars and bagworms in Malaysia, Latin America, and also Indonesia, outbreaks of the leaf miner Coelaenomenodera lameensis in West Africa, outbreaks of Fusarium wilt disease in Africa, considerable losses by dry basal rot (Ceratocystis sp.) in Nigeria, substantial losses by Ganoderma disease in old and replanted plantations in Asia, and few incidences of fatal yellowing and sudden wither in Latin America.

Local control of pests is, in general, no longer via "broad spectrum-long residual contactinsecticides” (bslrcs) neither from the ground nor from air, as outbreaks after application have become a major concern and these insecticides bslrcs is especially toxic to insect predators and parasites (Wood, 2002). More targeted use of insecticides such as injection into the palms can be used to replace the bslrcs (Chung, 1991; Philippe and Diarrassouba, 1979; Wood, 2002). For instance control of some defoliating pests such as Hispidae beetles and the bagworm Metisa plana using the injection technique to the oil palm trunk using monocrotophos, organophosphate 
insecticides was found to be costly, but very effective when carried out in the most sensitive stage in the pest’s life-cycle (Mariau et al., 1979; Sewify et al., 2009a), with the treatment having only a slight indirect effect on beneficial non-target insects (Kathirithamby et al., 1998; Mariau et al., 1979; Sewify et al., 2009a). Other chemical applications such as sex pheromone trapping for Lepidoptera and coleopteran pests have been investigated and promoted (Abdullah et al., 2012; Allou et al., 2006; Gries et al., 1994; Hallett et al., 1999a; Kamarudin et al., 2010; Oehlschlager et al., 1993; Poorjavad et al., 2009a). Nevertheless, sex pheromones might be only effective in trapping male imagos at low population densities, because at high population densities the male can find a female before getting trapped. Thus, the pheromone attractant is normaly used for monitoring pests, but not as pest control method.

Local biological control of pests by application of entomopathogenic fungi, viruses, or nematodes can cause a significant mortality of pests (Aponte and Olivares, 2008, 2008, 2008; Bakeri et al., 2009; Alois M. Huger, 2005; Kouassi et al., 1991; Mariau, 1982; Mariau and Dechenon, 1990; Mohan and Pillai, 1993; Ramle et al., 2005; Sewify et al., 2009b; Zeddam et al., 2003a, 2003b; Zelazny et al., 1992a). The management of the plantation floor can be important in managing pests. For instance, dense cover of the cover crop Pueraria javanica reduces both utilization of potential breeding sites by the rhinoceros beetle (O. rhinoceros), specifically the rotting trunks of a dead palms, and it protects the growing palms from pest attacks (Baligar and Fageria, 2007; Wood, 2002, 1969).

Studies of oil palm diseases focus more on the disease itself rather than its control. Understanding population dynamics and the mechanism of pathogen infection needs further research such as identification of pathogens and differentiating them from each other or from other factors (eg. symptoms caused by non abiotic factors such as fertilizer, temperature or humidity). Nevertheless, there are a few studies that tried to control the diseases with agronomic 
techniques, biological control, and pesticide application. The agronomic or cultural methods play important roles in delaying the appearance and development of diseases, reducing their incidence and increasing the chances of beneficial organisms developing in the field (Abadie et al., 1998; Chong et al., 2012b; Flood et al., 1993; Mepsted et al., 1995, 1994b; Paterson et al., 2009a; Renard and Franqueville, 1991). The application of fertilizers with increasing amounts of KCl can delay the appearance and development of vascular wilt, Fusarium oxysporum f.sp. elaeidis (Renard and Franqueville, 1991), and application of adequate amounts of tricalcium phosphate and/or potassium reduces the incidence of vascular wilt (Flood, 2006; Renard and Franqueville, 1991). The cover crop Calopogonium coeruleum encourages the vascular wilt expression, so bare soil could reduce the infection (Renard and Franqueville, 1991), but a different cover crop type, Pueraria javanica, increased degree of soil suppressiveness on the disease development (Abadie et al., 1998). As an alternative control of $G$. boninense, screening of oil palm varieties for resistance has been suggested. Resistant varieties include AVROS which is common in Sabah (Chong et al., 2012b) and F. Oxysporum, clone UF28 (Mepsted et al., 1995, 1994a; Susanto et al., 2005a). Nevertheless, even resistant varieties such as clone UF28 could be infected by the diseases due to increased pathogen virulence or aggressiveness in different regions or areas (Mepsted et al., 1994a). Good sanitation condition is known to have little effect on disease development (Renard and Franqueville, 1991), for instance the serious incidence of Marasmius bunch rot, Marasmius palmivorus, on the crop was found not to be caused by poor sanitation (Turner, 1967a).

Antagonist microorganisms are potential biological control agents of wilt diseases. Studies on in vitro cultures and on artificially infected oil palm seedlings indicate that the agent could potentially be applied against the disease in the field. The screening of fungicide formulas and activities against diseases in vitro has shown that numerous fungicides strongly inhibited $G$. 
boninense and M. palmivorus growth (Jollands, 1983; Turner, 1967a). However, the use of fungicides to control the disease in the field needs more investigation on the effectiveness and appropriate selection of the methods. For instance the application using soil drenching was not succesful to control G. boninense, especially in oil palm plantations with a history of a high disease incidence (Flood et al., 2000), but trunk injection method using the fungicides Bromoconazole or triadimenol can limit the spread of the disease infection and increase the economic life span of the crop (Arifin and Idris, 1997; Chung, 1991; Flood et al., 2000).

Biocontrol agents that have been investigated can be grouped into entomopathogenic agents, predators, and parasitoids in controling the oil palm pests; and microbial antagonism agents for controling the crop diseases (Appendix 2). The entomopathogenic agents, including fungi, viruses, and nematodes, have been applied to control insect pests: 1) Trunk borer pests such as $O$. rhinoceros and R. ferrugineus controlled by Baculovirus, Metarhizium anisopliae, and Beauveria bassiana show significant pest decline to negligible level after approximately ten months application; while controlling rootworm Sagalassa valida using nematode Steinernema carpocapsae revealed the caterpillars can be easily infected particullarly if they are inside the primary root (Aponte and Olivares, 2008; A. M. Huger, 2005; Mohan and Pillai, 1993; Moslim et al., 2011a, 2007; Ramle et al., 2005; Sewify et al., 2009b); 2) Controling defoliators or leaf-eater pests using entomopathogenic agent show the rapid and massive pest mortality within short period of application (around 90\% mortality can be reached after one - two weeks of application), e.g. Norape argyrrhorea by cypovirus, Euprosterna elaeasa using nucleopolyhedrovirus, and Latoia viridissima by picornavirus, a nuclear polyhedrosis baculoviruses, and ribovirus (Fediere et al., 1990; Kouassi et al., 1991; Mariau and Dechenon, 1990; Zeddam et al., 1990, 2003a). Predators and parasitoids control insect pests such as defoliator or leaf-eater pests, e.g insectivorous birds decreased pest attacks by leaf-eating lepidopteran between $1.2-17.2$ fold; a 
significant lower attack by the bagworm, Pteroma pendula, by the present of Oecophylla smaragdina; Brachymeria SPP and Callimerus arcufer were reported can control Metisa plana (Lepidoptera: Psychidae) from 38 larvae/frond to $<10$ larvae/frond within 4 years; parasitoid Trichospilus diatraeae and a stinkbug Alcaeorrhynchus grandis show reduce caterpillar pests considerably in commercial oil palm plantation (Basri et al., 1995; Kamarudin and Wahid, 2010; Koh, 2008b; Mariau et al., 1978; Pierre and Idris, 2013; Ribeiro et al., 2013, 2010; Tinoco et al., 2012). Birds such as barn owls (Tyto alba javanica) potentially control rats (Rattus tiomanicus and $R$. diardii) below 5\% damage by placing one owl in 2 - 10 ha plantation (Chong Leong Puan et al., 2011; Wood and Fee, 2003). Controlling oil palm diseases using microbial antagonism agents, such as ability of Trichoderma harzianum to reduce $60 \%$ incidence of wilt diseases $G$. boninense in artificial infected oil palm seedling; and potential control of chitinolytic endophyte bacteria (Pseudomonas aeruginosa and Burkholderia cepacia) on the disease where in vitro studies showed inhibitory effect of the bacteria on the disease growth (Bivi et al., 2010a; Siddiquee et al., 2009a; Sundram et al., 2011, 2008a; Suryanto et al., 2012a; Susanto et al., 2005b).

Generally speaking, use of enthomopathogenic agents, antagonist agents, predators, and parasitoids all are biocontrol approaches that could effectively regulate pests and diseases, and have the potential to be used for control of insect pests in the field. More specifically, for example, controlling Norape argyrrhorea (Lepidoptera pest) using an entomopathogenic virus, e.g. NoarCPV-based formulation, in the field, shows a significant reduction (99\%) of larva number, and a lab study of the effect of entomopathogenic fungi, Paecilomyces spp, on the first larval instars of bagworm, Pteroma pendula, shows $75 \%$ mortality of the larvae by P. farinosus and 93.8\% by P. carneus (Bakeri et al., 2009; Zeddam et al., 2003b). Biocontrol of stem rotcausing G. boninense using antagonist agents is possible, e.g.the application of chitinolytic 
endophyte bacteria showed a decrease of basal stem rot disease occurrence in oil palm seedlings to some extend (Suryanto et al., 2012b). Furthermore, a well-known study of the widely applied biocontrol by using predator barn owls to control rats, reports that one owl per 10 ha can reduce the damage by the pest below the $5 \%$ damage threshold (Ho and Teh, 1997). The parasitoid Paratheresia menezesi (a tachinid fly) can parasitize R. palmarum by 51.1\% in only one year application with an average number of 18.33 parasitoid larvae per beetle (Moura et al., 1993).

Whilst the efficacy of most biocontrol agents may be clear enough whether in the lab or in the field, the affordability of the biocontrol according to presence or absence of the control are still unclear. For instance, the biocontrol of rats using barn owls is low-cost compared with the regular chemical baiting method. It reduces the cost by up to $91.4 \%$, needs only low manpower during method utilization, and it is environmentally friendly. Field applications of nucleopolyhedrovirus (N-PV) (EuelNPV), on controlling the leaf-eater Euprosterna elaeasa is 2.5 times cheaper compared to the application of the pyrethroid pesticides (Zeddam et al., 2003a). Even though the costs of biocontrol applications are lower compared to chemical pesticides, application of biocontrol agents in large areas of the plantation through the inundative method still needs further economic assessment. For example, NoarCPV-based formulation for controlling Norape argyrrhorea (Lepidoptera pest) requires large amounts of the virus to control the pest, which is costly and application is laborious (Zeddam et al., 2003c). Thus, nowadays several biocontrol methods are still unaffordable for farmers. Especially among farmer with a limited budget biocontrol of pests or diseases still faces difficulties to be accepted and applied in the field.

The sustainability of biological control of pests and diseases is frequently questioned because it highly depends on conserving and enhancing the biocontrol agent in the field (Tscharntke et al., 2007). In oil palm crops, studies of biocontrol agents in the field are mostly 
based on artificial infections or controls where the biological material used for both activities were exotic agent in the habitat. Of special interest are native biocontrol agents because, being native, they are more likely to be sustainable than introduced agents. Nevertheless, according to Foster et al., (2011) the only publication on the links between native biocontrol and the pests or diseases in oil palm plantations is a study by Koh, (2008) on controlling herbivorous insects with birds. Most biocontrol studies in oil palm, whether dealing with pests or diseases, lack empirical evidence of the long-term conservation of biocontrol agents in the field.

\section{B. Effect of local and landscape management on pest, diseases and biocontrol}

One of the main problems with conservation approaches to sustainable biological control is a lack of understanding regarding the landscape perspective (Tscharntke et al., 2007). The majority of biocontrol studies pays no attention to landscape factors even though conservation of natural enemies in plantations depends on processes in the surrounding landscape (Kareiva and Wennergren, 1995; Ricklefs and Schluter, 1993). Several empirical studies have shown the importance of landscape composition and configuration, local agricultural intensification, proportion of semi-natural habitats close-by for presence and effectiveness of biocontrol agents (Bianchi et al., 2006; Martin et al., 2013; Tscharntke et al., 2007). However, no direct biocontrol study in oil palm addressed the effect of landscape management on biocontrol agents (Foster et al., 2011; Savilaakso et al., 2014; Wood, 2002). Thus, there is an urgent need for experimental evidence in order to be able to design oil palm landscape composition and configuration in a way that conserves and enhances (native) biocontrol agents in oil palm fields.

Although reviews on biocontrol studies have shown that there is only one study directly linked to native biocontrol of the pests and diseases; and no study on the effect of landscape management on the organisms, there may still be some implicit information available from 


\title{
previous studies which might explain the relative importance of landscape management on
}

\author{
conserving and fostering native biocontrol agents in oil palm plantations. In spite of the landscape \\ management, the effects of local managements are also explained because the managements also
}

have significant roles in influencing the organism population in the field.

\section{Pesticide applications}

Table 1. The effect of pesticide applications on organisms, in particular on pests, diseases and biocontrol agents.

\begin{tabular}{|c|c|}
\hline Organisms & Effect of Pesticide Application \\
\hline \multicolumn{2}{|l|}{ General Info } \\
\hline Legumes & $\begin{array}{l}\text { - Application of herbicide contributed to foster legume development and yield, resulting in } \\
\text { greater quantities of nutrients available to the developing oil palms compared to hand } \\
\text { weeding (Agamuthu et al., 1980) }\end{array}$ \\
\hline Soil microorganisms & $\begin{array}{l}\text { - Most pesticides inhibit soil microorganisms and decrease the soil fertility (Fianko, 2011). } \\
\text { - The amount of real detectable residue in soil is insignificant. Thus, the herbicides have no } \\
\text { significant effect on the crops and soil microorganisms (bacteria and fungi), and the level } \\
\text { of residue in soil is not detrimental (Wibawa et al., 2010a). }\end{array}$ \\
\hline \multicolumn{2}{|l|}{ Specific Objective } \\
\hline General pests & $\begin{array}{l}\text { - Severe insect pests outbreaks are usually due to uncontrolled use of pesticides (Gitau et } \\
\text { al., 2009). }\end{array}$ \\
\hline Coelaenomenodera & $\begin{array}{l}\text { - The adults and larvae can be controlled by injecting a systemic insecticide such as } \\
\text { monocrotophos into the trunk (Mariau et al., 1979; Philippe and Diarrassouba, 1979). }\end{array}$ \\
\hline Marasmius palmivorus & $\begin{array}{l}\text { - Several fungicide compounds from } 32 \text { tested formulae show strong inhibition of fungal } \\
\text { growth (Turner, 1967b) }\end{array}$ \\
\hline Metisa plana & $\begin{array}{l}\text { - Systemic insecticides poured into the trunk give good control of this pest and the residual } \\
\text { effect does not seem to last as long in the crops (Wood et al., 1974a). }\end{array}$ \\
\hline Darna trima & $\begin{array}{l}\text { - Some problems occur due to trunk injected chemicals, monocrotophos, and } \\
\text { methamidophos, for controlling the pest (Parra et al., 2009). } \\
\text { - A much higher dosage of pesticide is required in several plantation in order to control the } \\
\text { pest, suggesting that the pest has developed tolerance to the chemical (Darus and Basri } \\
\text { Wahid, 2001). }\end{array}$ \\
\hline Rattus tanezumi & $\begin{array}{l}\text { - The species demonstrated physiological tolerance to the chemical used for controlling the } \\
\text { pest (Andru et al., 2013a). }\end{array}$ \\
\hline Weedy plant & $\begin{array}{l}\text { - Herbicide effectively reduced the weed plant population. The herbicide was also } \\
\text { susceptible to biodegradation and therefore contamination of ground water is probably } \\
\text { low (Halimah et al., 2005; Ikuenobe and Ayeni, 1998; Mohamad et al., 2009; Wibawa et } \\
\text { al., 2010a). }\end{array}$ \\
\hline Goosegrass population & $\begin{array}{l}\text { - High intensity spraying of herbicide glufosinateammonium was unsuccessful in } \\
\text { controlling the Goosegrass population, presumably due to selection, leaving only the } \\
\text { resistant biotype remaining in the field (Jalaludin et al., 2010) }\end{array}$ \\
\hline Coelaenomenodera elaeidis Mlk & $\begin{array}{l}\text { - The pest is controlled by pesticide using the injection technique. No residues are found in } \\
\text { the crop fruits. The treatment has only a slight indirect effect on beneficial non-target } \\
\text { insects (Mariau et al., 1979). }\end{array}$ \\
\hline
\end{tabular}


Opsiphanes cassina

Rhodnius prolixus
- The insecticide used can repel the pest, because the smell of the chemical is not pleasant for pest when looking for food and nutritive substances (Parra et al., 2009).

- The pest is highly susceptible to the used insecticide. The insecticide residue persists about 15 months after the application (Mazariego-Arana et al., 2002a).

Table 1 lists the body of knowledge on the impact of pesticides on pests, diseases and weed in oil palm, and address issues of effectiveness and impacts on non-target organisms. Insecticides, when used, are commonly applied from the ground or air, but Mariau et al (1979) reveal that in the case of controlling a common trunk borer, Coelaenomenodera elaeidis Mlk, the chemical tends to have irregular effectiveness and toxicity to insect predators and parasitoids. Thus, from field studies of Philippe and Diarrassouba (1979) and Mariau (1979) trunk-injected chemicals were recommended to reach the best moment of the pest's life-cycle, and also to reduce residues on leaves and fruits which could have adverse effects on beneficial organisms. However, field research by Parra et al (2009) on Opsiphanes cassina, found that trunk injected chemicals are not always ideal. In several plantations the treatment barely controlled the pest, so a much higher pesticide dosage was required. This incident might suggest that the pest population has developed tolerance to the chemical. Moreover, a field study on rat, Rattus tanezumi (Rodentia: Muridae) by Andru et al, 2013, also showed chemical tolerance where rats subjected to extensive rodenticides were more susceptible than rats subjected to intensive chemical use. Other reviews of pesticide application by Darus and Wahid, 2000 on the nettle caterpillar, Darna trima, (Lepidoptera: Limacodidae) and field studies by Jalaludin at al., 2010 on Goosegrass populations, show the physiological tolerance of those species subjected to intensive applications, which have led to the resistant biotypes. Studies on herbicide application focus on the efficacy and adverse effects on the environment rather than specifically on the pest or disease. If herbicides are applied at very low and at the recommended rates and if they quickly degrade, the potential residues have low impact. In fact, no soil residual activity and practically no known environmental hazards 
have been detected (Halimah et al., 2005; Ikuenobe and Ayeni, 1998; Mohamad et al., 2009;

Wibawa et al., 2010b; Wood et al., 1974a). However, incorrect use of the chemicals such as drift or misdirected spraying can cause damage to non-target organisms (Gitau et al., 2009). Some herbicides significantly decrease soil fertility in the plantation, where an astonishing variety of microbes in soil may be beneficial in controlling pathogens (Fianko, 2011), but the net effect was still unclear (Wibawa et al., 2010b). Tuner (1967) shows the effectiveness of the fungicide is uncertain, although systemic fungicides are likely effective in laboratory tests and up to now, no follow-up study exists. Turner, 1967, said the efficacy of the chemical is limited by the fact that there is a lag between the time of the treatment application and disease controlling progress, meaning that infection is still in progress inside the crop even after the application. An additional challenge is the correct placement of fungicides in the plant, as lesions are frequently very large in size.

\section{Fertilizer application}

Table 4. Effect of fertilizer application on organisms inside the plantation

\begin{tabular}{|c|c|}
\hline Organisms & Effect of Fertilizer \\
\hline \multicolumn{2}{|l|}{ General Info } \\
\hline Oil palm crop & - Fertilizers are important for increasing the crop yield in many plantations (Singh et al., 2010). \\
\hline Soil microorganisms & - Adding empty fruit bunches promotes microorganisms in the soil (Susanto et al., 2005c). \\
\hline \multicolumn{2}{|l|}{ Specific Objective } \\
\hline General Pest and disease & $\begin{array}{l}\text { - Unscientific disposal of palm oil mill waste (POMW) could be contaminated with pests and } \\
\text { diseases (Embrandiri et al., 2011). However, composts contain an astonishing variety of } \\
\text { microbes, which may be beneficial in controlling pathogens (Oviasogie et al., 2010a). } \\
\text { - Soil nutrition can influence disease development, but the effect appears to be related to the } \\
\text { nature of the soil and its chemical properties (Flood et al., 2000). }\end{array}$ \\
\hline Wilt disease (general) & $\begin{array}{l}\text { - Potassium is an important factor in disease resistance (Flood, 2006; Ntsefong et al., 2012a; } \\
\text { Pilotti, 2005; PRENDERGAST, 1957; Rankine and Fairhurst, 1999; Singh et al., 2010). } \\
\text { Potassium deficiency has been associated with the occurrence of Vascular Wilt Disease, } \\
\text { Cercospora Leaf Spot, Ganoderma Basal Stem Rot, and the physiological disorders which } \\
\text { cause bunch and plant failure (Rankine and Fairhurst, 1999). } \\
\text { - The effectiveness of antagonists of the diseases in soil can be enhanced by fertilizer } \\
\text { application (Flood et al., 2000). } \\
\text { - Mass production of antagonist agent (Trichoderma) on oil-palm waste, such as oil palm mill } \\
\text { effluent and empty fruit bunches could be used for application around the roots of infected oil } \\
\text { palms (Flood et al., 2000). }\end{array}$ \\
\hline Fusarium diseases & $\begin{array}{l}\text { - The application of potassium reduces disease incidence (Flood et al., 2000; Ntsefong et al., } \\
\text { 2012a; Oritsejafor, 1986; Renard and Franqueville, 1991). }\end{array}$ \\
\hline
\end{tabular}


Ganoderma diseases

Crown diseases
- Low K fertilizer contents favor the development of vascular wilt of the oil palm (Ntsefong et al., 2012a).

- Increase in the total growth of the fungus as the carbon concentration (sucrose) increases, but no significant increase in growth was recorded with increase in the nitrogen (KN03) of the medium (Oritsejafor, 1986).

- The application of fertilizers with increasing amounts of $\mathrm{KCl}$ delayed the appearance and development of this disease; and tricalcium phosphate reduced the incidence of the disease (Renard and Franqueville, 1991).

- Rock phosphate and muriate of potash (kcl) significantly increased disease incidence, whereas urea had a reducing effect (Singh, 1991).

- Muriate of potash significantly reduced disease incidence, whereas urea and rock phosphate had a slightly promoting effect (Singh, 1991).

- High sodium content and low nitrogen levels have both been associated with raised disease levels, but both high and low magnesium contents have been linked with increased incidence of disease, so the situation is unclear (Akbar et al., 1971; Dell, 1955).

- Infection rates are low on the oil-palm roots collected from inland soils which contain high level of phosphate (p), zinc (Zn) and iron (Fe) (Singh, 1991).

- Carbon, nitrogen and manganese are critical variables and altering these as a control method may prevent Ganoderma attack (Paterson, 2007).

- Limiting carbon, nitrogen, and sulphur can trigger lignin degradation and conversely ensuring that they are available to oil palms may limit the rot (Paterson, 2007).

- Stress due to soil type, soil depth, and poor nutrition can elevate disease levels (Pilotti, 2005).

- The closest link between disease levels and palm nutrition has been seen in fertilizer trials where potassium (as $\mathrm{KCl}$ ) appears to have a significantly positive effect on disease levels (Pilotti, 2005).

- It is likely that the nutritional amelioration allows greater tolerance to the disease in susceptible palms rather than actually preventing infection (Pilotti, 2005).

- Soil factors such as $\mathrm{pH}$, conductivity, and nutrition can affect disease development (Singh et al., 2010).

- The relation between crown disease and nutritional status was inconsistent (Breure and Soebagjo, 1991).

- The difference in some nutrient levels between affected and unaffected palms following recovery may be a residual effect of the bending of the leaves rather than a direct cause (Breure and Soebagjo, 1991).

The relation between oil palm disease and nutritional status is still questionable as nutrient analyses associated with the disease symptoms have not been studied (Table 4). Field studies done by Pilloti (2005), Breure and Soebagjo (1991) show that the severity of Ganoderma and Crown disease do not appear to be associated with fertilizer use. There is also no consistent results from past studies explaining why the disease severity appears to be significantly influenced by soil structure and chemical properties (Flood et al., 2000). Fertilization might increase crop tolerance to the diseases, especially for susceptible oil palm varieties, rather than actually preventing attacks on the crop. Review studies by Singh (1991) and Renard and Franqueville (1991) demonstrate that soil nutrition can influence disease development. Several 
macro and micro nutrients significantly increase or decrease disease incidence of the oil palm wilt disease, the most studied disease, in the field dependent on the soil type in the plantation (Flood et al., 2000; Oritsejafor, 1986; Paterson, 2007; PRENDERGAST, 1957; Rankine and Fairhurst, 1999; Renard and Franqueville, 1991). In addition, composts contain an astonishing variety of microbes beneficial in controlling pathogens (Oviasogie et al., 2010a; Singh et al., 2010). An antagonistic mechanism occurs when a beneficial organism produces chemicals toxic to a pathogen or prey, resulting in natural enemies filling an ecological niche that would otherwise be exploited by a pathogen. Methods such as digging holes around the palm and adding empty fruit bunches appear to be the best methods for promoting biological agents in the field (Susanto et al., 2005d). Also, application of oil-palm waste, oil-palm mill effluent and empty fruit containing antagonist agents (Trichoderma spp.) around the roots, could be useful for reducing the wilt disease incidences.

\section{Effect of oil palm conversion, surroundings and proximity to border}

Table 3. Effect of vegetation surrounding oil palm plantations on organisms specifically related to oil palm pests, diseases, and biocontrol

\begin{tabular}{ll}
\hline Organisms & Effects of conversion (CE), Surroundings (SE), and of proximity to border (PE) \\
\hline General Info & $\begin{array}{l}\text { PE: density of adult palms decreases by approximately } 50-100 \% \text {, but juvenile palms wer not } \\
\text { affected (Baez and Balslev, 2007). }\end{array}$ \\
\hline Oil palm crop & CE: $60-95 \%$ loss of species richness (Aratrakorn et al., 2006a). PE: no effect of distance from \\
forest (Fisher et al., 2011). \\
Bird
\end{tabular}




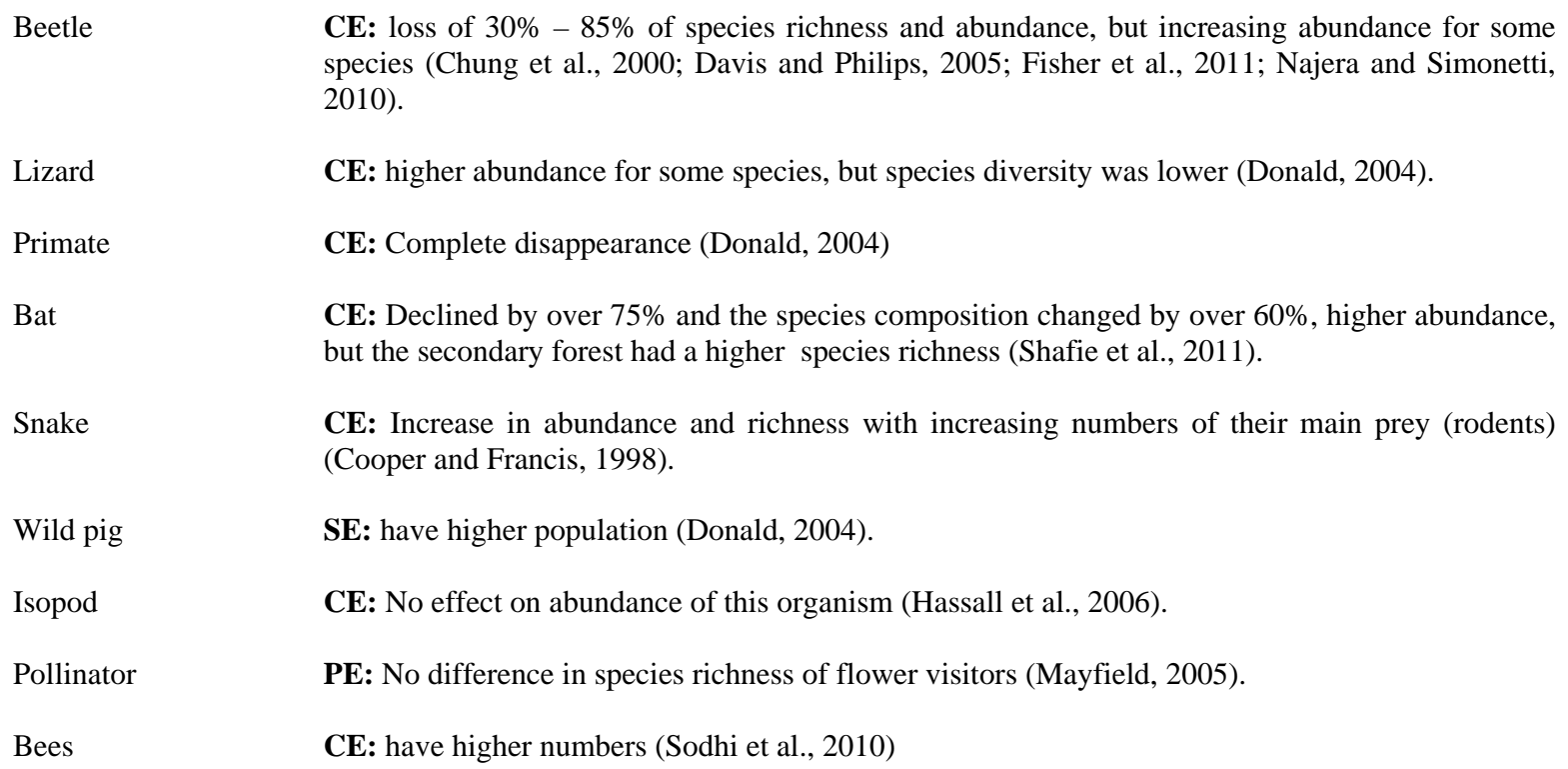
species (Chung et al., 2000; Davis and Philips, 2005; Fisher et al., 2011; Najera and Simonetti, 2010).

Lizard $\quad$ CE: higher abundance for some species, but species diversity was lower (Donald, 2004).

Primate CE: Complete disappearance (Donald, 2004)

Bat CE: Declined by over $75 \%$ and the species composition changed by over $60 \%$, higher abundance, but the secondary forest had a higher species richness (Shafie et al., 2011).

Snake $\quad$ CE: Increase in abundance and richness with increasing numbers of their main prey (rodents) (Cooper and Francis, 1998).

Wild pig SE: have higher population (Donald, 2004).

Isopod CE: No effect on abundance of this organism (Hassall et al., 2006).

Pollinator $\quad$ PE: No difference in species richness of flower visitors (Mayfield, 2005).

Bees $\quad$ CE: have higher numbers (Sodhi et al., 2010)

\begin{tabular}{ll}
\hline Specific Objective & \\
\hline Insectivorous birds & $\begin{array}{l}\text { CE: Very few of the insectivorous birds are able to adapt their diet when natural forests are } \\
\text { converted to oil palm (Aratrakorn et al., 2006b). Excluding birds from patches of oil palm resulted } \\
\text { in a significant increase in insect damage (Koh, 2008b). }\end{array}$ \\
$\begin{array}{l}\text { Herbivores and } \\
\text { Predatory beetles }\end{array}$ & $\begin{array}{l}\text { CE: More herbivores (abundance) but fewer predators (species richness and abundance), low } \\
\text { predatory beetle populations might explain the high population of Chrysomelid pest in oil-palm } \\
\text { plantations (Chung et al., 2000). }\end{array}$ \\
\hline
\end{tabular}

Table 3 show studies on the conversion of forests to oil palm plantations, the proximity of oil palm to different border habitats, and the effects of oil palm surroundings on diversity and abundance of organisms relevant to oil palm pests, diseases, and biocontrol. Oil palm conversion decreases most forest specialists, due to low habitat suitability and a decline in food resources. More specifically, conversion leads to a decrease in biological control agents and an increased dominance of some oil palm pests. The biocontrol conservation in oil palm plantations seems to depend on factors such as complex vegetation types which can be seen from the effect of the conversion . For example, during forest conversion to oil palm plantations, only small numbers of insectivorous birds are able to adapt, resulting in higher pest herbivory, which in turn influences oil palm yield (Aratrakorn et al., 2006b; Koh, 2008a). Higher numbers of herbivorous beetles rather than predatory beetles are found within oil palm plantations compared with primary or secondary forest, which explains increases in pest attacks (Chung et al., 2000). The information 
from these two taxa (of birds and beetles) has important implications for pest management as vegetation surrounding or within oil palm plantations that resemble forest could promote insectivorous birds and predatory beetles within plantations and help regulate invasive species and pest outbreaks in oil palm plantations. Thus, retaining forest areas within or close to plantations plays an important role in species dispersal through the landscape, increasing the chance of spillover of beneficial organisms from forest to plantations. For instance, even though most birds are sensitive to habitat disturbance (Koh, 2008a), some studies report that they can survive in the plantations, especially insectivorous birds which feed also on the oil palm pests e.g. Setora nitens, Metisa plana, and Segestes spp (Koh, 2008b). However, Koh, (2008), reveals that secondary forest in plantation surroundings is irreplaceable habitat for bird reproduction and provides temporally reliable, additional food resources. The absence of forest vegetation, namely forest trees, lianas, and epiphytic orchids in plantations is the main reason for the conversionassociated changes because plantations are structurally less complex than forests (Persey and

Anhar, 2010).

\section{Effect of oil palm understory}

Table 4. The effects of oil palm vegetation cover on organisms, in particular pests, diseases, and natural enemies

\begin{tabular}{|c|c|}
\hline Organisms & Effects of Oil Palm Understory \\
\hline \multicolumn{2}{|l|}{ General Info } \\
\hline Birds & $\begin{array}{l}\text { - Bird species richness increases through retaining undergrowth and epiphytes in the plantation } \\
\text { (Asrulsani Jambari et al., 2012; De Chenon and Susanto, 2006; Koh, 2008c). } \\
\text { - Having epiphytes on oil palm tree can increase bird richness by } 1.5 \text { and } 2.2 \text { species with no } \\
\text { or leguminous crops respectively (Koh, 2008a). }\end{array}$ \\
\hline Butterflies & $\begin{array}{l}\text { - Slightly higher number in plantations where epiphytes or undergrowth is present (Koh, } \\
\text { 2008a, 2008b). } \\
\text { - Increasing the percentage ground cover of weeds from } 0 \% \text { to } 70 \% \text { only increase the species } \\
\text { richness by } 0.4 \text { species (Koh, 2008a). }\end{array}$ \\
\hline Beetles & $\begin{array}{l}\text { - More beetles are at the plantation borders than in the plantation interior and also when the } \\
\text { breeding sites are covered by vegetation (Wood, 2002, 1969; Young, 1986). }\end{array}$ \\
\hline \multicolumn{2}{|l|}{ Specific Objective } \\
\hline Insectivorous Birds & $\begin{array}{l}\text { - Modification of vegetation in the plantation interior, such as ground vegetation cover and } \\
\text { epiphytes on palm trees, can maintains insectivorous birds in the plantation (Koh, 2008b). } \\
\text { - Ground and epiphytic ferns (e.g. Nephrolepsis biserrata) offer nesting sites for several }\end{array}$ \\
\hline
\end{tabular}


insectivorous birds such as Orthotomus ruficeps, Pycnonotus goiavier and Prinia flaviventris (De Chenon and Susanto, 2006)

Parasitic and predatory insects

Pests

Beetle pests

Microbiology

Crown diseases

Pesticide uses

Wilt diseases

Rats
- Insect predators and parasitoids are attracted by several flowering plant species, reducing insect pest abundance and avoid their outbreaks (Basri et al., 1995; Catherine Wanjiru Gitau et al., 2011; Kamarudin and Wahid, 2010; Najera and Simonetti, 2010; Wood, 2002).

- Vegetation cover in a cropping system is mainly beneficial for control of pests (Baligar and Fageria, 2007; Gitau et al., 2009; Najera and Simonetti, 2010; Wood, 2002).

- Using cover crops offers suitable habitat and nectar for beneficial insects, which simultaneously helps to lower pest populations (Catherine Wanjiru Gitau et al., 2011).

- Some legumes, Pueraria phaseoloides and Arachis pintoi, can provide poor breeding sites for an insect pest, Myndus crudus, which means the legumes do not support development of eggs or other immature stages of some insect pests (Catherine Wanjiru Gitau et al., 2011).

- The denser the vegetation cover the lower the incidence of palms severely damaged by beetle pests (Bedford, 1980; Chung et al., 2000; Effraim, 1996; Wood, 2002, 1969; Young, 1986).

- Ground vegetation cover suppresses beetle pest damage in oil palm related to vegetative barriers and concealing potential breeding sites (Wood, 2002).

- Ground cover crops improve microbiological activities (Baligar and Fageria, 2007).

- Beneficial effects of the vegetation depend on the selection of appropriate cover crops and their management (Baligar and Fageria, 2007).

- Maintenance of a pure inter-row cover of Pueraria phaseloides and Calopogonium caeruleum reduces incidence of the disease (Breure and Soebagjo, 1991).

- Widespread use of leguminous cover crops reduces the use of insecticides and herbicides in the plantation (Fitzherbert et al., 2008)

- Lower disease occurrence detected in the soil cultivated with a specific cover-plant (Abadie et al., 1998; Flood, 2006; Ntsefong et al., 2012a; Renard and Franqueville, 1991).

- Occurrence of rats is positively correlated with percent vegetation cover and height of vegetation (C.L. Puan et al., 2011).

- Understory vegetation is used for nest construction and for moving around, while being protected from predators (Buckle et al., 1997).

Table 4 shows that the absence of epiphytes and ground cover can enhance populations of several

organisms in plantations. Retaining understory within the oil palm plantation results in slight

increases in bird, butterfly, and beetle species richness, and these groups declined after the

understory was removed. The height of the vegetation cover, the spacing and age of the

vegetation had a positive effect on total species richness. Besides, conserving primary and

secondary forest within and around plantations, increasing ground cover within plantations is

promoted as a tool to increase organism abundance and species richness in plantations. Several

field studies carried out by Abadie et al (1998), Basri et al (1995), Breure and Soebagjo (1991),

Chung et al (2000), Effraim (1996), Kamarudin and Wahid (2010), Najera and Simonetti (2010), 
Chenon and Susanto (2006) have shown that higher vegetation inside the plantation helps to control certain pests and diseases. Literature review studies on oil palm understory also support the notion that modifying the local vegetation characteristics to maintain natural pest control services also reduces the cost of pest and disease management by pesticide application. However, field studies by Puan et al. (2011) and Buckle et al. (1997) show that the understory can also be beneficial to some oil palm pests, especially rats. Thus, rather than reducing the understory, it is recommended to grow and manage specific suitable flora inside the plantation that serves as food resources for beneficial organisms such as insect predators and parasitoids. In addition, appropriate flora might provide poor breeding and development sites for pests, and act as vegetative barrier; which results in reducing pest and disease attacks on the crop. Modification of local vegetation characteristics could make oil palm plantations more hospitable for biocontrol agents by promoting the conservation of natural enemies.

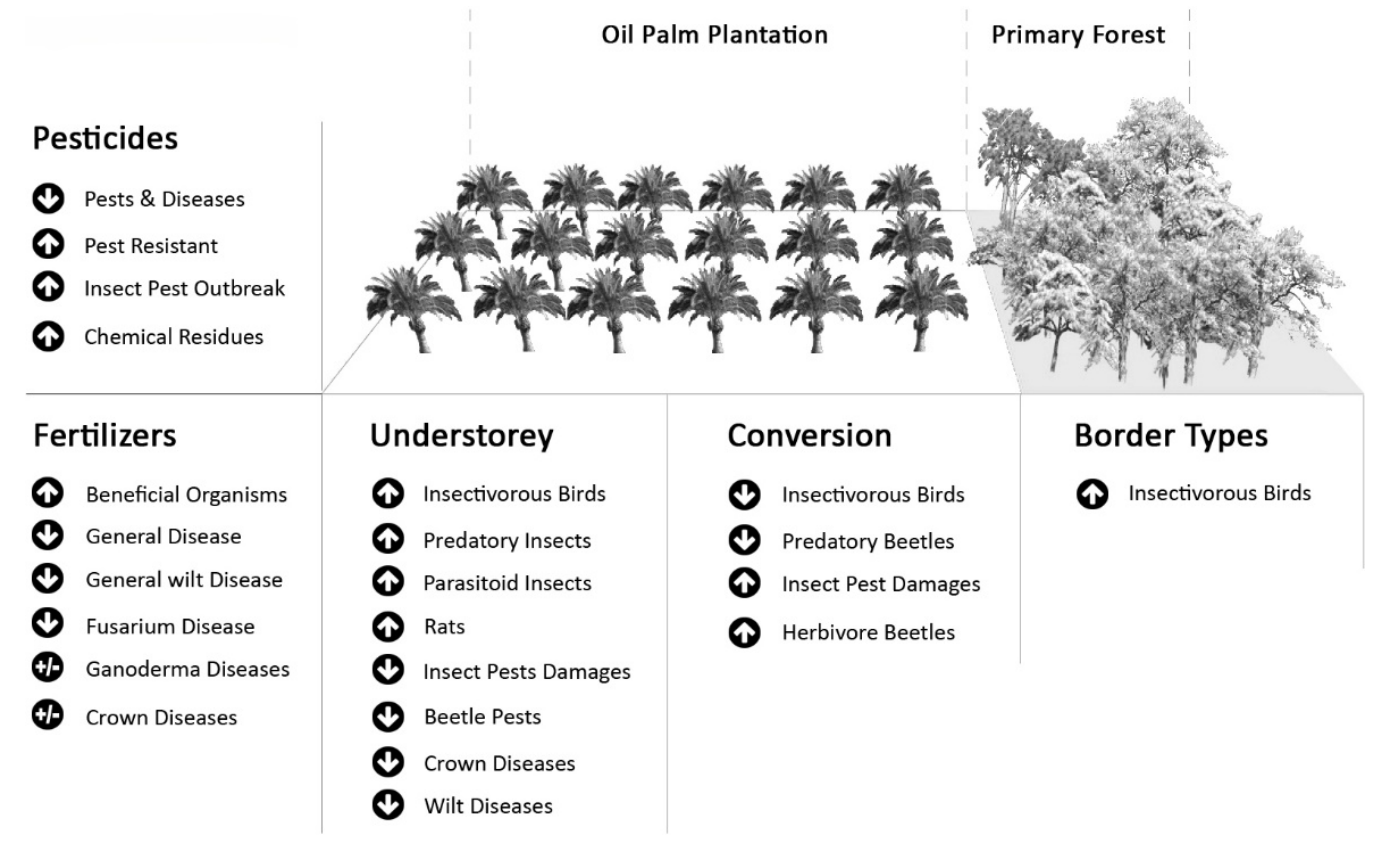

Figure 2. Summary of the effects of local and landscape management of oil palm on pests, diseases, and biocontrol. The local managements include pesticides and fertilizers applications, while landscape managements include retaining surrounding vegetation (border types) and growing specific plants as understorey. Conversion means the transformation from forest to oil palm plantation and border types the type of nonoil palm vegetation adjacent to the oil palm plantation. 


\section{Conclusion}

This paper reviews the evidence how local and landscape management affect the occurrence of pests, diseases, and their biological control in oil palm plantations. We found a number of studies addressing the impact of management on pests and diseases, as well as the relationship between these organisms and their natural enemies (Figure 2).

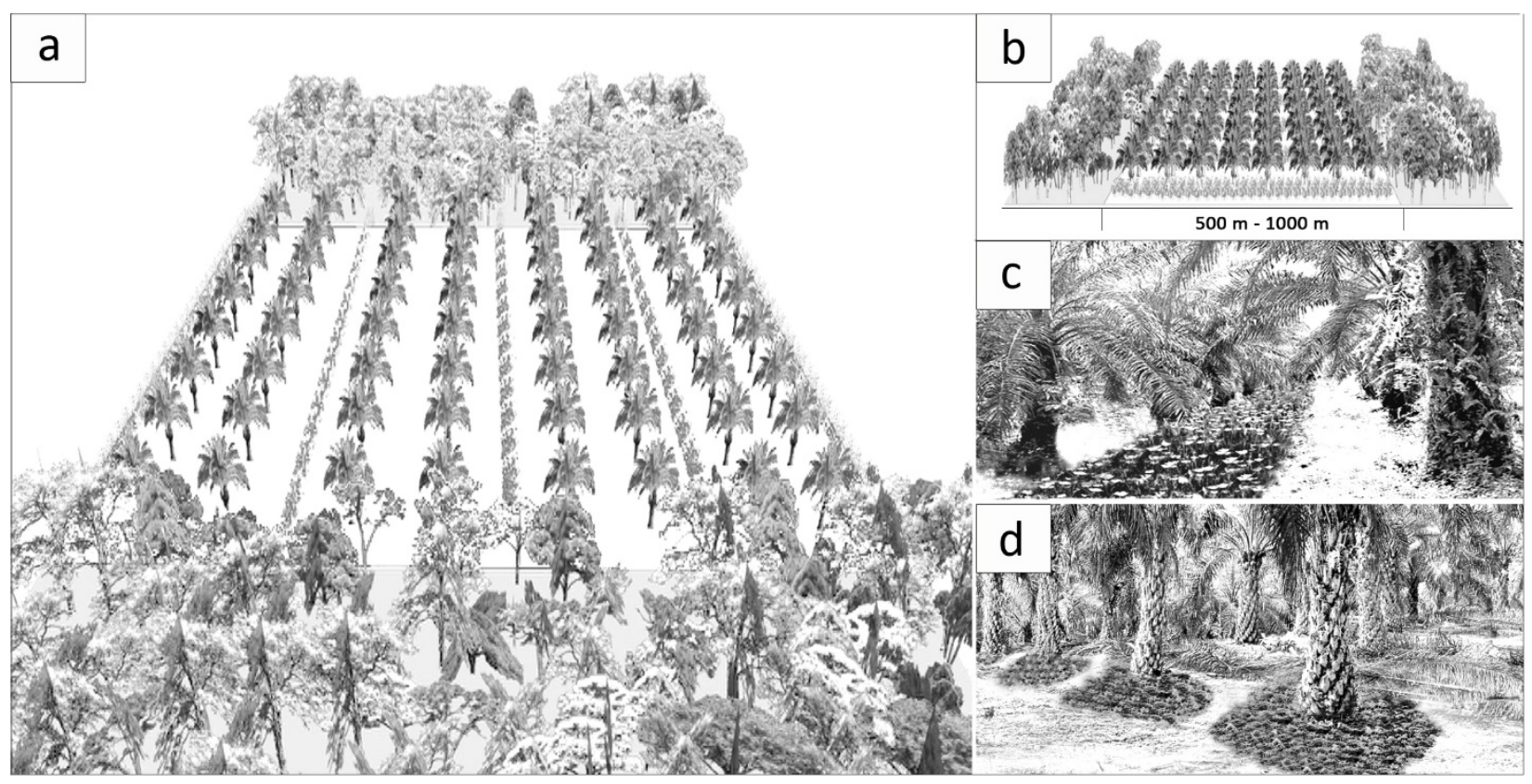

Figure 3. Recommendation of local and landscape management of oil palm for improving sustainability of pest and disease control by the biocontrol method. a) a design of oil palm plantation where vegetation surroundings and understory are present, b) $500-1000 \mathrm{~m}$ might be the optimum distance of each vegetation surrounding, c) arranggement of specific weedy or flowering plants in the corridor of oil palm plantations, d) application of empty fruit bunches containing antagonist agents (Trichoderma spp) around the roots.

Retaining forested areas within and surrounding plantations plays an important role in maintaining ecosystem functions such as the biological control of pests and diseases (Figure 3a\&b). Allowing or supporting the establishment of understory or cover crops in oil palm plantations will increase the abundance and richness of biocontrol agents (Figure 3c). Pesticide applications have deleterious effect, not only in terms of residues (often associated with incorrect use), but also by causing resistant pest and disease populations. Thus, restraining the pesticide usage to recommended rates and products with quick biodegradation, the potential impacts to the 
environment from residues are minimized. The impact of soil structure and chemical composition is poorly understood and results on the relationship between oil palm disease and nutritional status are inconsistent, but studies often recommend applying macro and micro nutrients to reduce disease incidence as well as to promote development of biological agents (Figure 3d).

Management that ensures the sustainability of palm production systems requires a sound understanding of the interactions between local and landscape management for pests and disease infestation as well as biocontrol. Researchers are increasingly recognizing that the assessment of biological regulation of pests and diseases requires a landscape perspective. Even though oil palm pests and diseases have been managed using different kinds of biocontrol methods, studies concerning the conservation of the natural enemies are still lacking. A general consensus is emerging that the only way to conserve biocontrol agents in the plantation is by understanding the factors influencing the organism's development in the field. There is an urgent need for a better understanding of the ecological factors affecting and driving incidence rates, which will be a prerequisite for formulating sustainable management strategies. 


\section{Reference List}

Abadie, C., Edel, V., Alabouvette, C., 1998. Soil suppressiveness to Fusarium wilt: Influence of a cover-plant on density and diversity of Fusarium populations. Soil Biol. Biochem. 30, 643-649. doi:10.1016/S0038-0717(97)00154-5

Abdullah, A.H., Adom, A.H., Shakaff, A.Y.M., Ahmad, M.N., Saad, M.A., Tan, E.S., Fikri, N.A., Markom, M.A., Zakaria, A., 2011. Electronic Nose System for Ganoderma Detection. Sens. Lett. 9, 353-358. doi:10.1166/sl.2011.1479

Abdullah, F., Sabri, M.S.M., Sina, I., Fauzee, F., Isa, S.M., 2012. Response of the male bagworm moth (Metisa plana Walker, Lepidoptera: Psychidae) towards female bagworm pheromone lure in wind tunnel bioassays. Asia Life Sci. 21, 375-389.

Abdullah, S.A., Hezri, A.A., 2008. From forest landscape to agricultural landscape in the developing tropical country of Malaysia: pattern, process, and their significance on policy. Environ. Manage. 42, 907-917. doi:10.1007/s00267-008-9178-3

Aderungboye, F.O., 1977. Diseases of the Oil Palm. PANS 23, 305-326. doi:10.1080/09670877709412457

Agamuthu, P., Chan, Y.K., Jesinger, R., Khoo, K.M., Broughton, W.J., 1980. Effect of diphenyl ether pre-emergence herbicides on legume cover establishment under oil palm (Elaeis guineensis Jacq.). Agro-Ecosyst. 6, 193-208. doi:10.1016/0304-3746(80)90021-9

Agodan, A., 1980. Pests and diseases of the oil palm and coconut - new control methods against termites harmful to the coconut in West-Africa. Oleagineux 35, 145-146.

Akbar, U., Kusnadi, M., Ollagnier, M., 1971. Influence of the type of planting materials and of mineral nutrients on oil palm stem rot due to Ganoderma. Oleagineux 26, 527-534.

Alizadeh, F., Abdullah, S.N.A., Khodavandi, A., Abdullah, F., Yusuf, U.K., Chong, P.P., 2011. Differential expression of oil palm pathology genes during interactions with Ganoderma boninense and Trichoderma harzianum. J. Plant Physiol. 168, 1106-1113. doi:10.1016/j.jplph.2010.12.007

Allou, K., Morin, J.-P., Kouassi, P., N’klo, F.H., Rochat, D., 2006. Oryctes monoceros trapping with synthetic pheromone and palm material in Ivory Coast. J. Chem. Ecol. 32, 17431754. doi:10.1007/s10886-006-9106-z

Al-Obaidi, J.R., Mohd -Yusuf, Y., Chin-Chong, T., Mhd-Noh, N., Othman, R.Y., 2010. Identification of a partial oil palm polygalacturonase-inhibiting protein (EgPGIP) gene and its expression during basal stem rot infection caused by Ganoderma boninense. Afr. J. Biotechnol. 9, 7788-7797.

Alvarez, E., Llano, G.A., Loke, J.B., Chacon, M.I., 2012. Characterization of Thielaviopsis paradoxa Isolates from Oil Palms in Colombia, Ecuador and Brazil. J. Phytopathol. 160, 690-700. doi:10.1111/jph.12012

Andru, J., Cosson, J.F., Caliman, J.P., Benoit, E., 2013a. Coumatetralyl resistance of Rattus tanezumi infesting oil palm plantations in Indonesia. Ecotoxicology 22, 377-386. doi:10.1007/s10646-012-1032-y

Andru, J., Cosson, J.F., Caliman, J.P., Benoit, E., 2013b. Coumatetralyl resistance of Rattus tanezumi infesting oil palm plantations in Indonesia. Ecotoxicology 22, 377-386. doi:10.1007/s10646-012-1032-y

Anonymous, 1981. Oil palm and coconut pests in West-Africa. Oleagineux 36, 170-217.

Anonymous, 1978. Oil palm pests in Latin-America. Oleagineux 33, 326-419. 
Aponte, A.S., Olivares, W., 2008. Searching capacity of the entomopathogenic nematode Steinernema sp SNIO 198 (Rhabditida : Steinernematidae). Rev. Colomb. Entomol. 34, 51-56.

Aratrakorn, S., Thunhikorn, S., Donald, P.F., 2006a. Changes in bird communities following conversion of lowland forest to oil palm and rubber plantations in southern Thailand. Bird Conserv. Int. 16, 71. doi:10.1017/S0959270906000062

Aratrakorn, S., Thunhikorn, S., Donald, P.F., 2006b. Changes in bird communities following conversion of lowland forest to oil palm and rubber plantations in southern Thailand. Bird Conserv. Int. 16, 71. doi:10.1017/S0959270906000062

Arifin, D., Idris, A.., 1997. Chemical control of Ganoderma using pressure injection, in: Proceedings of the PORIM-Industry Forum. Bangi, Malaysia, pp. 104-106.

Asrulsani Jambari, Badrul Azhar, Nor Laili Ibrahim, Syari Jamian, Arnina Hussin, Puan ChongLeong, Hafidzi Mohd Noor, Ebil Yusof, Mohamed Zakaria, 2012. Avian biodiversity and conservation in Malaysian oil palm production areas. J. Oil Palm Res. 24, 1277-1286.

Attias, M., Bezerra, J., Deoliveira, D., Desouza, W., 1987. Ultrastructure of phytomonas-staheli in diseased coconut (cocos-nucifera) and oil palm (Elaeis guineensis). J. Submicrosc. Cytol. Pathol. 19, 93-100.

Austin, A.D., 1987. A review of the Braconidae (Hymenoptera) that parasitize Limacodidae in Southeast Asia, particulary those associated with coconut and oil palm pp. 139-184 In: Cock MJ. Slug Nettle Caterp. CAB Int. Lond.

Azadeh, B.F., Sariah, M., Wong, M.Y., 2010a. Characterization of Burkholderia cepacia genomovar I as a potential biocontrol agent of Ganoderma boninense in oil palm. Afr. J. Biotechnol. 9, 3542-3548.

Azadeh, B.F., Sariah, M., Wong, M.Y., 2010b. Characterization of Burkholderia cepacia genomovar I as a potential biocontrol agent of Ganoderma boninense in oil palm. Afr. J. Biotechnol. 9, 3542-3548.

Baez, S., Balslev, H., 2007. Edge effects on palm diversity in rain forest fragments in western Ecuador. Biodivers. Conserv. 16, 2201-2211. doi:10.1007/s10531-007-9159-5

Bakeri, S.A., Ali, S.R.A., Tajuddin, N.S., Kamaruzzaman, N.E., 2009. Efficacy of entomopathogenic fungi, Paecilomyces spp., in controlling the oil palm bagworm, Pteroma pendula (Joannis). J. Oil Palm Res. 21, 693-699.

Baligar, V.C., Fageria, N.K., 2007. Agronomy and physiology of tropical cover crops. J. Plant Nutr. 30, 1287-1339. doi:10.1080/01904160701554997

Basiron, Y., 2007. Palm oil production through sustainable plantations. Eur. J. Lipid Sci. Technol. 109, 289-295. doi:10.1002/ejlt.200600223

Basri, M.W., Abdul Halim, H, Zulkipli M., 1988. Bagworms (Lepidoptera: Psychidae) of Oil Palms in Malaysia. PORIM Occas. Pap. 23, : 1-23.

Basri, M.W., Norman, K., Hamdan, A.B., 1995. Natural enemies of the bagworm, Metisa plana Walker (Lepidoptera: Psychidae) and their impact on host population regulation. Crop Prot. 14, 637-645. doi:10.1016/0261-2194(95)00053-4

Bedford, G.O., 1980. Biology, ecology, and control of palm rhinoceros beetles. Annu. Rev. Entomol. 25, 309-339.

Bergou, J.A., Hillery, M., 2013. Introduction to the Theory of Quantum Information Processing. Springer. 
Beuther, E., Wiese, U., Lukacs, N., Vanslobbe, W., Riesner, D., 1992. Fatal yellowing of oil palms - search for viroids and double-stranded-rna. J. Phytopathol.-Phytopathol. Z. 136, 297-311. doi:10.1111/j.1439-0434.1992.tb01312.x

Bianchi, F.J.J.., Booij, C.J.., Tscharntke, T., 2006. Sustainable pest regulation in agricultural landscapes: a review on landscape composition, biodiversity and natural pest control. Proc. R. Soc. B Biol. Sci. 273, 1715-1727. doi:10.1098/rspb.2006.3530

Bivi, M.R., Farhana, M.S.N., Khairulmazmi, A., Idris, A., 2010a. Control of Ganoderma boninense: A Causal Agent of Basal Stem Rot Disease in Oil Palm with Endophyte Bacteria In Vitro. Int. J. Agric. Biol. 12, 833-839.

Bivi, M.R., Farhana, M.S.N., Khairulmazmi, A., Idris, A., 2010b. Control of Ganoderma boninense: A Causal Agent of Basal Stem Rot Disease in Oil Palm with Endophyte Bacteria In Vitro. Int. J. Agric. Biol. 12, 833-839.

Blaak, G., 1970. Epistasis for crown disease in oil palm (Elaeis guineensis Jacq). Euphytica 19, 22-. doi:10.1007/BF01904661

Blaak, G., 1969. Prospects of breeding for blast disease resistance in oil palm (Elaeis guineensis Jacq). Euphytica 18, 153-.

Breure, C.J., Soebagjo, F.X., 1991. Factors associated with occurrence of crown disease in oil palm (Elaeis guineensis Jacq.) and its effect on growth and yield. Euphytica 54, 55-64.

Brühl, C.A., Eltz, T., 2009. Fuelling the biodiversity crisis: species loss of ground-dwelling forest ants in oil palm plantations in Sabah, Malaysia (Borneo). Biodivers. Conserv. 19, 519529. doi:10.1007/s10531-009-9596-4

Buckle, A.P., Chia, T.H., Fenn, M.G.P., Visvalingam, M., 1997. Ranging behaviour and habitat utilisation of the Malayan wood rat (Rattus tiomanicus) in an oil palm plantation in Johore, Malaysia. Crop Prot. 16, 467-473. doi:10.1016/S0261-2194(97)00010-0

Carter, C., Finley, W., Fry, J., Jackson, D., Willis, L., 2007. Palm oil markets and future supply. Eur. J. Lipid Sci. Technol. 109, 307-314. doi:10.1002/ejlt.200600256

Caudwell, R.W., 2000. The successful development and implementation of an integrated pest management system for oil palm in Papua New Guinea. Integr. Pest Manag. Rev. 5, 297301.

Chan, J.J., Latiffah, Z., Liew, K.W., Idris, A.S., 2011. Pathogenicity of monokaryotic and dikaryotic mycelia of Ganoderma boninense on oil palm seedlings and germinated seeds in Malaysia. Australas. Plant Pathol. 40, 222-227. doi:10.1007/s13313-011-0031-4

Chinchilla, C., Menjivar, R., Arias, E., 1990. The palm weevil (Rhynchophorus palmarum) and red ring disease in a Honduran commercial plantation. Turrialba 40, 471-477.

Chinchilla, C., Richardson, D., 1990. Pollination of Oils Palms (elaeis-Guineensis Jacq) in Central-America .1. Insect Populations and Fruit-Set. Turrialba 40, 452-460.

Chong, K.P., Atong, M., Rossall, S., 2012a. The role of syringic acid in the interaction between oil palm and Ganoderma boninense, the causal agent of basal stem rot. Plant Pathol. 61, 953-963. doi:10.1111/j.1365-3059.2011.02577.x

Chong, K.P., Lum, M.S., Foong, C.P., Wong, C.M.V.L., Atong, M., Rossall, S., 2011. First identification of Ganoderma boninense isolated from Sabah based on PCR and sequence homology. Afr. J. Biotechnol. 10, 14718-14723. doi:10.5897/AJB11.1096

Chong, K.P., Markus, A., Rossall, S., 2012b. The susceptibility of different varieties of oil palm seedlings to Ganoderma boninense infection. Pak. J. Bot. 44, 2001-2004.

Chung, A.Y.C., Eggleton, P., Speight, M.R., Hammond, P.M., Chey, V.K., 2000. The diversity of beetle assemblages in different habitat types in Sabah, Malaysia. Bull. Entomol. Res. 90, 475-496. 
Chung, G.., 1991. Preliminary results on trunk injection of fungicides against ganoderma basal stem rot in oil palm, in: Proccedings of Ganoderma Workshop. Palm Oil Research Institute of malaysia, Bangi, selangor, Malaysia, pp. 81-97.

Cooper, D.S., Francis, C.M., 1998. Nest predation in a Malaysian lowland rain forest. Biol. Conserv. 85, 199-202.

Cooper, R.M., Rusli, M.H., 2014. Threat from Fusarium Wilt Disease of Oil Palm to South-East Asia and Suggested Control Measures. J. Oil Palm Res. 26, 109-119.

Córdova-Ballona, L., Sánchez-Soto, S., 2008. Bionomics data and descriptions of the immatures of Calyptocephala gerstaeckeri Boheman (Coleoptera: Chrysomelidae), pest of the oil palm (Elaeis guineensis J.) and camedor palm (Chamaedorea elegans Mart.)(Arecaceae) in Tabasco, Mexico. Neotrop. Entomol. 37, 674-680.

Corley, R.H.V., Tinker, P.B.H., 2008. The Oil Palm. John Wiley \& Sons.

Cruz, M., Reyes, Y., 1991. Initial results in controlling Euprosterna elaesa Dyar a leaf-eating pest on oil palm (Elaeis guineensis Jacq) using triflumuron and teflubenzuron, chitin synthesis inhibitors. Oleagineux 46, 139-145.

Darus, A., Basri Wahid, M., 2001. Intensive IPM for management of Oil Palm Pests. Malays. Palm Oil Board Kuala Lumpur Malays. 41.

Davis, A.L.V., Philips, T.K., 2005. Effect of Deforestation on a Southwest Ghana Dung Beetle Assemblage (Coleoptera: Scarabaeidae) at the Periphery of Ankasa Conservation Area. Environ. Entomol. 34, 1081-1088. doi:10.1603/0046225X(2005)034[1081:EODOAS]2.0.CO;2

De Chenon, R.D., Susanto, A., 2006. Ecological observations on diurnal birds in Indonesian oil palm plantations. J Oil Palm Res Spec. Issue-April 122-143.

De Franqueville, H., 2003. Oil palm bud rot in Latin America. Exp. Agric. 39, 225-240. doi:10.1017/S0014479703001315

Defranqueville, H., Renard, J., 1990. Improvement of oil palm vascular wilt tolerance - results and development of the disease at the Michaux, R. plantation. Oleagineux 45, 399-405.

Defranqueville, H., Renard, J., 1988. Oil palm wilt in replantings - study methods and determination of certain environmental-factors on the expression of this disease. Oleagineux 43, 155-157.

Defranqueville, H., Renard, J., Philippe, R., Mariau, D., 1991. Oil palm blast - prospects for improvement of the control method. Oleagineux 46, 223-231.

Dell, E., 1955. De aantasting van de oliepalm op Sumatra door Ganoderma lucidum. Bergcultures 24, 191-203.

Desmierdechenon, R., 1979. Demonstration of the role of Recilia mica Kramer in blast disease in oil palm nurseries in the Ivory-Coast. Oleagineux 34, 107-115.

Desmierdechenon, R., Mariau, D., Renard, J., 1977. New method of controlling blast disease in oil palm. Oleagineux 32, 515-517.

Dewhurst, C.F., 2011. Pests of Oil palm in Papua New Guinea, with emphasis on West New Britain. Phytopathology 101, S219-S219.

Dhileepan, K., 1991. Insect pests of intercrops and their potential to infest oil palm in an oilpalm-based agroforestry system in India. Trop. Pest Manag. 37, 57-58.

Dhileepan, K., 1989. Investigations on avian pests of oil palm, Elaeis-guineensis Jacq in India. Trop. Pest Manag. 35, 273-277.

Diabate, S., de Franqueville, H., Adon, B., Coulibaly, O.A., Ake, S., 2009. The role of phenolic compounds in the determination of wilt disease tolerance of oil palm (Elaeis guineensis JACQ). Afr. J. Biotechnol. 8, 5679-5690. 
Dollet, M., 1982. Intraphloemic flagellate protozoa (Phytomonas sp trypanosomatidae) diseases of the oil palm and coconut in Latin-America. Oleagineux 37, 11-12.

Dollet, M., Sturm, N.R., Ahomadegbe, J.C., Campbell, D.A., 2001a. Kinetoplast DNA minicircles of phloem-restricted Phytomonas associated with wilt diseases of coconut and oil palms have a two-domain structure. Fems Microbiol. Lett. 205, 65-69. doi:10.1111/j.1574-6968.2001.tb10926.x

Dollet, M., Sturm, N.R., Campbell, D.A., 2001b. The spliced leader RNA gene array in phloemrestricted plant trypanosomatids (Phytomonas) partitions into two major groupings: epidemiological implications. Parasitology 122, 289-297. doi:10.1017/S0031182001007417

Dominguez-Guerrero, I.P., Mohali-Castillo, S.R., Marin-Montoya, M.A., Pino-Menesini, H.B., 2012. Characterization and genetic variability of Colletotrichum gloeosporioides sensu lato in oil palm (Elaeis guineensis Jacq.) plantations from Venezuela. Trop. Plant Pathol. 37, 108-122.

Donald, P.F., 2004. Biodiversity impacts of some agricultural commodity production systems. Conserv. Biol. 18, 17-37. doi:10.1111/j.1523-1739.2004.01803.x

Douaho, A., 1984. Pests and diseases of oil palm and coconut - biological-control of Pseudotheraptus and related species. Oleagineux 39, 257-262.

Duff, A., 1962. Bud rot disease of oil palm. Nature 195, 918-. doi:10.1038/195918b0

Durand-Gasselin, T., Asmady, H., Flori, A., Jacquemard, J.C., Hayun, Z., Breton, F., de Franqueville, H., 2005. Possible sources of genetic resistance in oil palm (Elaeis guineensis Jacq.) to basal stem rot caused by Ganoderma boninense - prospects for future breeding. Mycopathologia 159, 93-100. doi:10.1007/s11046-004-4429-1

Dzido, J., Genty, P., Ollagnier, M., 1978. Principal oil palm diseases in Ecuador - FR,S. Oleagineux 33, 55-63.

Effraim, N.O., 1996. Biology, economic impact and potential for semiochemical-based control of mahogany shootborer, Hypsipyla robusta (Moore)(Lepidoptera: Pyralidae), African rhinoceros beetle, Oryctes monoceros (Olivier)(Coleoptera: Scarabaeidae) and maize weevil, Sitophil. Theses (Dept. of Biological Sciences)/Simon Fraser University.

Embrandiri, A., Singh, R.P., Ibrahim, H.M., Ramli, A.A., 2011. Land application of biomass residue generated from palm oil processing: its potential benefits and threats. The Environmentalist 32, 111-117. doi:10.1007/s10669-011-9367-0

Fairhurst, T., McLaughlin, D., 2009. Sustainable oil palm development on degraded land in Kalimantan. Wash. DC World Wildl. Fund.

Fediere, G., Philippe, R., Veyrunes, J., Monsarrat, P., 1990. Biological-control of the oil palm pest Latoia-viridissima [lepidoptera, limacodidae], in cote-divoire, by a new Picornavirus. Entomophaga 35, 347-354. doi:10.1007/BF02375258

Fianko, J.R., 2011. Agrochemicals and the Ghanaian Environment, a Review. J. Environ. Prot. 2, 221-230. doi:10.4236/jep.2011.23026

Fisher, B., Edwards, D.P., Larsen, T.H., Ansell, F.A., Hsu, W.W., Roberts, C.S., Wilcove, D.S., 2011. Cost-effective conservation: calculating biodiversity and logging trade-offs in Southeast Asia. Conserv. Lett. 4, 443-450. doi:10.1111/j.1755-263X.2011.00198.x

Fitzherbert, E., Struebig, M., Morel, A., Danielsen, F., Bruhl, C., Donald, P., Phalan, B., 2008. How will oil palm expansion affect biodiversity? Trends Ecol. Evol. 23, 538-545. doi:10.1016/j.tree.2008.06.012

Flood, J., 2006. A review of Fusarium wilt of oil palm caused by Fusarium oxysporum f. sp. elaeidis. Phytopathology 96, 660-662. 
Flood, J., Bridge, P.D., Holderness, M., 2000. Ganoderma diseases of perennial crops [electronic resource]. CABI.

Flood, J., Mepsted, R., Cooper, R., 1994. Population-dynamics of Fusarium species on oil palm seeds following chemical and heat-treatments. Plant Pathol. 43, 177-182. doi:10.1111/j.1365-3059.1994.tb00568.x

Flood, J., Mepsted, R., Velez, A., Paul, T., Cooper, R., 1993. Comparison of virulence of isolates of Fusarium-oxysporum f-sp Elaeidis from Africa and South-America. Plant Pathol. 42, 168-171. doi:10.1111/j.1365-3059.1993.tb01487.x

Flood, J., Whitehead, D.S., Cooper, R.M., 1992. Vegetative compatibility and DNA polymorphisms in Fusarium oxysporum f.sp. elaeidis and their relationship to isolate virulence and origin. Physiol. Mol. Plant Pathol. 41, 201-215. doi:10.1016/08855765(92)90011-J

Foster, W.A., Snaddon, J.L., Turner, E.C., Fayle, T.M., Cockerill, T.D., Ellwood, M.D.F., Broad, G.R., Chung, A.Y.C., Eggleton, P., Khen, C.V., Yusah, K.M., 2011. Establishing the evidence base for maintaining biodiversity and ecosystem function in the oil palm landscapes of South East Asia. Philos. Trans. R. Soc. B Biol. Sci. 366, 3277-3291. doi:10.1098/rstb.2011.0041

Genty, P., 1977. Pests and diseases of oil palm and coconut - root-miner lepidoptera-sagalassavalida-w. Oleagineux 32, 311-316.

Gibson, G.A.P., Dewhurst, C., Makai, S., 2012. Nomenclatural changes in Anastatus Motschulsky and the description of Anastatus eurycanthae Gibson n. sp (Eupelmidae: Eupelminae), an egg parasitoid of Eurycantha calcarata Lucas (Phasmida: Phasmatidae) from Papua New Guinea. Zootaxa 53-61.

Gitau, C.W., Gurr, G.M., Dewhurst, C.F., Fletcher, M.J., Mitchell, A., 2009. Insect pests and insect-vectored diseases of palms. Aust. J. Entomol. 48, 328-342. doi:10.1111/j.14406055.2009.00724.x

Gitau, C.W., Gurr, G.M., Dewhurst, C.F., Mitchell, A., Fletcher, M.J., Liefting, L.W., Cowling, A., 2011. Zophiuma lobulata (Hemiptera: Lophopidae) causes Finschhafen disorder of coconut and oil palms. Ann. Appl. Biol. 158, 139-148. doi:10.1111/j.17447348.2010.00450.x

Gitau, C.W., Gurr, G.M., Dewhurst, C.F., Nicol, H., Fletcher, M., 2011. Potential for biological control of Zophiuma butawengi (Heller) (Hemiptera: Lophopidae) in coconut and oil palms using the hymenopterans Ooencyrtus sp (Encyrtidae) and Parastethynium maxwelli (Girault) (Mymaridae). Biol. Control 59, 187-191. doi:10.1016/j.biocontrol.2011.07.008

Gomes De Oliveira, H., Aldana, R., Moya, O., Martinez, G., 2011. Rhynchophorus palmarum and Strategus aloeus management in oil palm plants affected by bud rot disease in Colombia. Phytopathology 101, S254-S254.

Gries, G., Gries, R., Perez, A.L., Oehlschlager, A.C., Gonzales, L.M., Pierce, H.D., 1994. Aggregation pheromone of the African rhinoceros beetle, Oryctes monoceros (Olivier)(Coleoptera: Scarabaeidae). Z. Für Naturforschung C 49, 363-366.

Guerrieri, E., Gitau, C.W., Fletcher, M.J., Noyes, J.S., Dewhurst, C.F., Gurr, G.M., 2011. Description and biological parameters of Ooencyrtus isabellae Guerrieri and Noyes sp nov (Hymenoptera: Chalcidoidea: Encyrtidae), a potential biocontrol agent of Zophiuma butawengi (Heller) (Hemiptera: Fulgoromorpha: Lophopidae) in Papua New Guinea. J. Nat. Hist. 45, 2747-2755. doi:10.1080/00222933.2011.616272 
Halimah, M., Tan, Y.A., Ismail, B.S., 2005. The fate of fluroxypyr in the soil in an oil palm agroecosystem. Weed Biol. Manag. 5, 184-189. doi:10.1111/j.1445-6664.2005.00179.x

Hallett, R.H., Oehlschlager, A.C., Borden, J.H., 1999a. Pheromone trapping protocols for the Asian palm weevil, Rhynchophorus ferrugineus (Coleoptera : Curculionidae). Int. J. Pest Manag. 45, 231-237. doi:10.1080/096708799227842

Hallett, R.H., Oehlschlager, A.C., Borden, J.H., 1999b. Pheromone trapping protocols for the Asian palm weevil, Rhynchophorus ferrugineus (Coleoptera : Curculionidae). Int. J. Pest Manag. 45, 231-237. doi:10.1080/096708799227842

Hallett, R.H., Oehlschlager, A.C., Borden, J.H., 1999c. Pheromone trapping protocols for the Asian palm weevil, Rhynchophorus ferrugineus (Coleoptera : Curculionidae). Int. J. Pest Manag. 45, 231-237. doi:10.1080/096708799227842

Hanold, D., Randles, J., 1991. Detection of coconut cadang-cadang viroid-like sequences in oil and coconut palm and other monocotyledons in the South-West Pacific. Ann. Appl. Biol. 118, 139-151. doi:10.1111/j.1744-7348.1991.tb06092.x

Hasan, Y., Foster, H.L., Flood, J., 2005. Investigations on the causes of upper stem rot (USR) on standing mature oil palms. Mycopathologia 159, 109-112. doi:10.1007/s11046-0044431-7

Hassall, M., Jones, D.T., Taiti, S., Latipi, Z., Sutton, S.L., Mohammed, M., 2006. Biodiversity and abundance of terrestrial isopods along a gradient of disturbance in Sabah, East Malaysia. Eur. J. Soil Biol. 42, S197-S207. doi:10.1016/j.ejsobi.2006.07.002

Ho, C.T., Teh, C.L., 1997. Integrated pest management in plantation crops in Malaysia: challenges and realities, in: Plantation Management for the 21st Century. Presented at the the International Planters Conference, Incorporated Societyof Planters, Kuala Lumpur, pp. 125-149.

Ho, Y., Varghese, G., Taylor, G., 1985. Fusarium-oxysporum var redolens from Africa as a cause of vascular wilt disease of oil palm. Phytopathol. Z.-J. Phytopathol. 113, 373-376.

Ho, Y.W., Varghese, G., 1986. Pathogenic Potential of Soil Fusaria from Malaysian Oil Palm Habitats. Pathog. Potential Von Fusarium Ölpalmengebieten Malays. 115, 325-331.

Huber, J.T., Gitau, C.W., Gurr, G.M., Dewhurst, C.F., Fletcher, M.J., 2011. Re-description and biology of Parastethynium maxwelli (Hymenoptera: Mymaridae), an egg parasitoid of Zophiuma lobulata (Hemiptera: Lophopidae), and description of a new species of Parastethynium from Indonesia. Zootaxa 49-62.

Huger, A.M., 2005. The Oryctes virus: Its detection, identification, and implementation in biological control of the coconut palm rhinoceros beetle, Oryctes rhinoceros (Coleoptera: Scarabaeidae). J. Invertebr. Pathol. 89, 78-84. doi:10.1016/j.jip.2005.02.010

Huger, A.M., 2005. The Oryctes virus: Its detection, identification, and implementation in biological control of the coconut palm rhinoceros beetle, Oryctes rhinoceros (Coleoptera : Scarabaeidae). J. Invertebr. Pathol. 89, 78-84. doi:10.1016/j.jip.2005.02.010

Hwa, L.F., Fakhrana, I.N., Shaharuddin, N.A., Abd Rasid, O., Abu Seman, I., Parveez, G.K.A., 2011. A partial-length cyclophilin-encoding (cyp) cdna isolated from Ganoderma boninense. J. Oil Palm Res. 23, 1115-1120.

Igbinosa, I.B., 1992. Field and laboratory techniques for assessing infestations of the nettle caterpillar, Latoia viridissima Holland (Lepidoptera: Limacodidae). Insect Sci. Its Appl. 13, 389-398.

Igbinosa, I.B., 1985. Life-table studies for the nettle caterpillar, $<\mathrm{i}>$ Latoia viridissima $</ \mathrm{i}>$ Holland, on the oil palm, $<\mathrm{i}>$ Elaeis guineensis $</ \mathrm{i}>$ Jacq., and the coconut palm, $<\mathrm{i}>$ Cocos nucifera $</ \mathrm{i}>$ L. Agric. Ecosyst. Environ. 14, 77-93. 
Ikuenobe, C.E., Ayeni, A.O., 1998. Herbicidal control of Chromolaena odorata in oil palm. WEED Res.-Oxf.- 38, 397-404.

Jakel, T., Khoprasert, Y., Endepols, S., Archer-Baumann, C., Suasa-ard, K., Promkerd, P., Kliemt, D., Boonsong, P., Hongnark, S., 1999. Biological control of rodents using Sarcocystis singaporensis. Int. J. Parasitol. 29, 1321-1330. doi:10.1016/S00207519(99)00081-8

Jalaludin, A., Ngim, J., Bakar, B.H. j., Alias, Z., 2010. Preliminary findings of potentially resistant goosegrass (Eleusine indica) to glufosinate-ammonium in Malaysia. Weed Biol. Manag. 10, 256-260. doi:10.1111/j.1445-6664.2010.00392.x

Jollands, P., 1983. Laboratory investigations on fungicides and biological agents to control 3 diseases of rubber and oil palm and their potential applications. Trop. Pest Manag. 29, 33-38.

Julia, J., 1979. Isolation and identification of insects carrying juvenile diseases of the coconut and the oil palm in the Ivory-Coast. Oleagineux 34, 385-393.

Kamarudin, N., Ahmad, S.N., Arshad, O., Wahid, M.B., 2010. Pheromone mass trapping of bagworm moths, Metisa plana Walker (Lepidoptera: Psychidae), for its control in mature oil palms in Perak, Malaysia. J. Asia-Pac. Entomol. 13, 101-106.

doi:10.1016/j.aspen.2009.11.003

Kamarudin, N., Wahid, M.B., 2010. Interactions of the bagworm, Pteroma pendula (Lepidoptera: Psychidae), and its natural enemies in an oil palm plantation in Perak. J. Oil Palm Res. 22, 758-764.

Kanga, F.N., Waeyenberge, L., Hauser, S., Moens, M., 2012. Distribution of entomopathogenic nematodes in Southern Cameroon. J. Invertebr. Pathol. 109, 41-51. doi:10.1016/j.jip.2011.09.008

Kareiva, P., Wennergren, U., 1995. Connecting landscape patterns to ecosystem and population processes. Nature 373, 299-302.

Kathirithamby, J., Simpson, S., Solulu, T., Caudwell, R., 1998. Strepsiptera parasites - novel biocontrol tools for oil palm integrated pest management in Papua New Guinea (vol 44, pg 127, 1998). Int. J. Pest Manag. 44, 261-+.

Kenne, M., Feneron, R., Djieto-Lordon, C., Malherbe, M.-C., Tindo, M., Ngnegueu, P.R., Dejean, A., 2009. Nesting and foraging habits in the arboreal ant Atopomyrmex mocquerysi ANDRE, 1889 (Hymenoptera: Formicidae: Myrmicinae). Myrmecol. News 12, 109-115.

Koh, L.P., 2008a. Can oil palm plantations be made more hospitable for forest butterflies and birds? J. Appl. Ecol. 45, 1002-1009. doi:10.1111/j.1365-2664.2008.01491.x

Koh, L.P., 2008b. Birds defend oil palms from herbivorous insects. Ecol. Appl. 18, 821-825. doi:10.1890/07-1650.1

Koh, L.P., 2008c. Can oil palm plantations be made more hospitable for forest butterflies and birds? J. Appl. Ecol. 45, 1002-1009. doi:10.1111/j.1365-2664.2008.01491.x

Koh, L.P., Levang, P., Ghazoul, J., 2009. Designer landscapes for sustainable biofuels. Trends Ecol. Evol. 24, 431-438. doi:10.1016/j.tree.2009.03.012

Kon, T.-W., Bong, C.-F.J., King, J.-H.P., Leong, C.-T.S., 2012. Biodiversity of termite (Insecta: Isoptera) in tropical peat land cultivated with oil palms. Pak. J. Biol. Sci. PJBS 15, 10820.

Kouassi, N., Fediere, G., Lery, X., Philippe, R., Bergoin, M., 1991. Detection of a nuclear polyhedrosis baculoviruses in latoia-viridissima, limacodid lepidoptera, an oil palm and coconut pest in Ivory-Coast. Oleagineux 46, 53-59. 
Kouassi, N., Fediere, G., Lery, X., Philippe, R., Bergoin, M., 1991. Detection Of A Nuclear Polyhedrosis Baculoviruses In Latoia-Viridissima, Limacodid Lepidoptera, An Oil Palm And Coconut Pest In Ivory-Coast. Oleagineux 46, 53-59.

Kovachich, W., 1948. A Preliminary Anatomical Note On Vascular Wilt Disease Of The Oil Palm (Elaeis-Guineensis). Ann. Bot. 12, 327-.

Latiffah, Z., Harikrishna, K., Tan, S.G., Tan, S.H., Abdullah, F., Ho, Y.W., 2002. Restriction analysis and sequencing of the ITS regions and $5.8 \mathrm{~S}$ gene of rDNA of Ganoderma isolates from infected oil palm and coconut stumps in Malaysia. Ann. Appl. Biol. 141, 133-142. doi:10.1111/j.1744-7348.2002.tb00205.x

Lee, M.-P., Yeun, L.-H., Abdullah, R., 2006. Expression of Bacillus thuringiensis insecticidal protein gene in transgenic oil palm. Electron. J. Biotechnol. 9, 117-126. doi:10.2225/vol9-issue2-fulltext-3

Lelong, C.C.D., Roger, J.-M., Bregand, S., Dubertret, F., Lanore, M., Sitorus, N.A., Raharjo, D.A., Caliman, J.-P., 2010. Evaluation of Oil-Palm Fungal Disease Infestation with Canopy Hyperspectral Reflectance Data. Sensors 10, 734-747. doi:10.3390/s100100734

Liau, S.S., 1987. Problems and control of bagworms (Lepidoptera: Psychidae) and rats (Rodentia: Muridae) in the oil palm, in: Proceedings of the Second Chemara Workshop. pp. 46-59.

Liau, S.S., Ahmad, A., 1991. The control of Oryctes rhinoceros by clean clearing and its effect on early yield in palm to palm replants, in: Proceedings of the 1991 PORIM International Palm Oil Development Conference-Module II (Agriculture).

Lucey, J.M., Hill, J.K., 2012. Spillover of Insects from Rain Forest into Adjacent Oil Palm Plantations. Biotropica 44, 368-377. doi:10.1111/j.1744-7429.2011.00824.x

Maddox, T., 2007. The Conservation of Tigers and Other Wildlife in Oil Palm Plantations: Jambi Province, Sumatra, Indonesia (October 2007). Zoological society of London (ZSL).

Marche, S., Roth, C., Manohar, S., Dollet, M., Baltz, T., 1993. Rna Virus-Like Particles In Pathogenic Plant Trypanosomatids. Mol. Biochem. Parasitol. 57, 261-268. doi:10.1016/0166-6851(93)90202-9

Mariau, D., 1993a. Integrated Control In Palm Plantations - Results. Oleagineux 48, 309-318.

Mariau, D., 1993b. Insecticides Recommended Against Oil Palm And Coconut Pests. Oleagineux 48, 530-532.

Mariau, D., 1982. Phyllophagous oil palm and coconut pests - importance of entomopathogenic parasites for population regulation. Oleagineux 37, 3-5.

Mariau, D., Dechenon, R., 1990. Importance of the role of entomopathogenic viruses in oil palm leaf-eating lepidoptera species - prospects for developing biological-control methods. Oleagineux 45, 487-491.

Mariau, D., Dechenon, R., 1990. Importance Of The Role Of Entomopathogenic Viruses In Oil Palm Leaf-Eating Lepidoptera Species - Prospects For Developing Biological-Control Methods. Oleagineux 45, 487-491.

Mariau, D., Dechenon, R., Sudharto, P., 1991. Oil Palm Insect Pests And Their Enemies In Southeast-Asia. Oleagineux 46, 400-472.

Mariau, D., Genty, P., 1992. Oil Palm And Coconut Pest-Control By Root Absorption. Oleagineux 47, 191-193.

Mariau, D., Philippe, R., Lecoustre, R., 1978. Larval parasites of Coelaenomenodera-elaeidismlk, oil palm hispid in West-Africa - introduction to a method of biological-control. Oleagineux 33, 153-160. 
Mariau, D., Philippe, R., Lecoustre, R., 1978. Larval Parasites Of Coelaenomenodera-ElaeidisMlk, Oil Palm Hispid In West-Africa - Introduction To A Method Of BiologicalControl. Oleagineux 33, 153-160.

Mariau, D., Philippe, R., Morin, J.P., 1979. Method of controlling Coelaenomenodera (Coleoptera Hispidae) by injecting systemic insecticides into the trunk of the oil palm. Oleagineux 34, 51-58.

Mariau, D., Vandelande, H., Renard, J., Dollet, M., Desouza, L., Rios, R., Orellana, F., Corrado, F., 1992. Oil Palm Bud Rot Type Diseases In Latin-America - Symptomatology Epidemiology Incidence. Oleagineux 47, 605-618.

Martin, E.A., Reineking, B., Seo, B., Steffan-Dewenter, I., 2013. Natural enemy interactions constrain pest control in complex agricultural landscapes. Proc. Natl. Acad. Sci. 110, 5534-5539. doi:10.1073/pnas.1215725110

Mayfield, M.M., 2005. The Importance of Nearby Forest to Known and Potential Pollinators of Oil Palm (Elaeis guineënsis Jacq.; Areceaceae) in Southern Costa Rica. Econ. Bot. 59, 190-196. doi:10.1663/0013-0001(2005)059[0190:TIONFT]2.0.CO;2

Mazariego-Arana, M.A., Ramirez-San Juan, E., Alejandre-Aguilar, R., Nogueda-Torres, B., 2002a. Activity and residual effect of two formulations of lambdacyhalothrin sprayed on palm leaves to Rhodnius prolixus. Mem. Inst. Oswaldo Cruz 97, 353-357.

Mazariego-Arana, M.A., Ramirez-San Juan, E., Alejandre-Aguilar, R., Nogueda-Torres, B., 2002b. Activity and residual effect of two formulations of lambdacyhalothrin sprayed on palm leaves to Rhodnius prolixus. Mem. Inst. Oswaldo Cruz 97, 353-357.

Mccoy, R., Martinezlopez, G., 1982. Phytomonas-Staheli Associated With Coconut And Oil Palm Diseases In Colombia. Plant Dis. 66, 675-677.

Mcghee, R., Mcghee, A., 1978. Comparative Morphology Of Phytomonas Spp Producing Disease In Oil And Coconut Palms. J. Protozool. 25, A21-A21.

Mepsted, R., Flood, J., Cooper, R., 1995a. Fusarium-Wilt Of Oil Palm .1. Possible Causes Of Stunting. Physiol. Mol. Plant Pathol. 46, 361-372. doi:10.1006/pmpp.1995.1028

Mepsted, R., Flood, J., Cooper, R., 1994a. Fusarium-Wilt of Oil Palm - Susceptibility of Some Palms of a Resistant Clone. Oleagineux 49, 205-208.

Mepsted, R., Flood, J., Cooper, R., 1994a. Fusarium-Wilt Of Oil Palm - Susceptibility Of Some Palms Of A Resistant Clone. Oleagineux 49, 205-208.

Mepsted, R., Flood, J., Paul, T., Airede, C., Cooper, R., 1995b. A Model System For Rapid Selection For Resistance And Investigation Of Resistance Mechanisms In Fusarium-Wilt Of Oil Palm. Plant Pathol. 44, 749-755. doi:10.1111/j.1365-3059.1995.tb01699.x

Mepsted, R., Flood, J., Paul, T., Airede, C., Cooper, R., 1995c. A Model System For Rapid Selection For Resistance And Investigation Of Resistance Mechanisms In Fusarium-Wilt Of Oil Palm. Plant Pathol. 44, 749-755. doi:10.1111/j.1365-3059.1995.tb01699.x

Mepsted, R., Flood, J., Paul, T., Airede, C., Cooper, R.M., 1995. A model system for rapid selection for resistance and investigation of resistance mechanisms in Fusarium wilt of oil palm. Plant Pathol. 44, 749-755. doi:10.1111/j.1365-3059.1995.tb01699.x

Mepsted, R., Flood, J., Paul, T., Cooper, R., 1994b. Virulence and Aggressiveness in FusariumOxysporum Fsp Elaeidis - Implications for Screening for Disease Resistance. Oleagineux 49, 209-212.

Mepsted, R., Flood, J., Paul, T., Cooper, R., 1994b. Virulence And Aggressiveness In FusariumOxysporum Fsp Elaeidis - Implications For Screening For Disease Resistance.

Oleagineux 49, 209-212. 
Michielse, C.B., Rep, M., 2009. Pathogen profile update: Fusarium oxysporum. Mol. Plant Pathol. 10, 311-324. doi:10.1111/J.1364-3703.2009.00538.X

Mohamad, R., Juraimi, A.S., Omar, D., Wibawa, W., Mohayidin, M.G., Begum, M., 2009. Weed control efficacy and short term weed dynamic impact of three nonselective herbicides in immature oil palm plantation. Int. J. Agric. Biol. 11, 145-150.

Mohammadi, M.R., Vadamalai, G., Joseph, H., 2010. An optimized method for extraction and detection of Coconut cadang-cadang viroid(CCCVd) from oil palm. Commun. Agric. Appl. Biol. Sci. 75, 777-81.

Mohan, K., Pillai, G., 1993. Biological-control of Oryctes-rhinoceros (l) using an indian isolate of Oryctes Baculovirus. Insect Sci. Its Appl. 14, 551-558.

Mohan, K., Pillai, G., 1993. Biological-Control Of Oryctes-Rhinoceros (L) Using An Indian Isolate Of Oryctes Baculovirus. Insect Sci. Its Appl. 14, 551-558.

Morales, F.J., Lozano, I., Velasco, A.C., Arroyave, J.A., 2002. Detection of a fovea-like virus in african oil palms affected by a lethal "ringspot" disease in South America. J. Phytopathol.-Phytopathol. Z. 150, 611-615. doi:10.1046/j.1439-0434.2002.00820.x

Moslim, R., Ghani, I., Wahid, M.B., Glare, T.R., Jackson, T.A., 2010. Optimization Of The Polymerase Chain Reaction (Pcr) Method For The Detection Of Oryctes rhinoceros VIRUS. J. Oil Palm Res. 22, 736-749.

Moslim, R., Kamarudin, N., Ghani, I.A., Wahid, M.B., Jackson, T.A., Tey, C.C., Ahdly, M., 2011a. Molecular Approaches In The Assessment Of Oryctes Rhinoceros Virus For The Control Of Rhinoceros Beetle In Oil Palm Plantations. J. Oil Palm Res. 23, 1096-1109.

Moslim, R., Kamarudin, N., Na, A.B., Ali, S.R.A., Wahid, M.B., 2007. Application of powder formulation of Metarhizium anisopliae to control 319 Oryctes rhinoceros in rotting oil palm residues under leguminous cover crops. J. Oil Palm Res. 19, 319-331.

Moslim, R., Kamarudin, N., Wahid, M.B., 2011b. Trap For The Auto Dissemination Of Metarhizium Anisopliae In The Management Of Rhinoceros Beetle, Oryctes Rhinoceros. J. Oil Palm Res. 23, 1011-1017.

Moslim, R., Kamarudin, N., Wahid, M.B., 2009. Pathogenicity Of Granule Formulations Of Metarhizium Anisopliae Against The Larvae Of The Oil Palm Rhinoceros Beetle, Oryctes Rhinoceros (L.). J. Oil Palm Res. 21, 602-612.

Moura, J., Mariau, D., Delabie, J., 1993. Effectiveness of Paratheresia-menezesi townsend (diptera, tachinidae) for the natural biological-control of Rhynchophorus-palmarum (l) (coleoptera, curculionidae). Oleagineux 48, 218-223.

Moura, J., Mariau, D., Delabie, J., 1993. Effectiveness Of Paratheresia-Menezesi Townsend (Diptera, Tachinidae) For The Natural Biological-Control Of Rhynchophorus-Palmarum (L) (Coleoptera, Curculionidae). Oleagineux 48, 218-223.

Moura, J.I.L., Toma, R., Sgrillo, R.B., Delabie, J.H.C., 2006. Natural efficiency of parasitism by Billaea rhynchophorae (Blanchard) (Diptera : tachinidae) for the control of Rhynchophorus palmarum (L.) (Coleoptera : curculionidae). Neotrop. Entomol. 35, 273274.

Moyses, D.N., Barrabin, H., 2004. Rotenone-sensitive mitochondrial potential in Phytomonas serpens: electrophoretic Ca2+ accumulation. Biochim. Biophys. Acta-Bioenerg. 1656, 96-103. doi:10.1016/j.bbabio.2004.02.003

Muller, E., Gargani, D., Schaeffer, V., Stevens, J., Fernandezbecerra, C., Sanchezmoreno, M., Dollet, M., 1994. Variability In The Phloem Restricted Plant Trypanosomes (Phytomonas Spp) Associated With Wilts Of Cultivated Crops - Isoenzyme Comparison With The Tower Trypanosomatids. Eur. J. Plant Pathol. 100, 425-434. doi:10.1007/BF01874809 
Murphy, D.J., 2009. Oil palm: future prospects for yield and quality improvements. Lipid Technol. 21, 257-260. doi:10.1002/lite.200900067

Murphy, D.J., 2007. Future prospects for oil palm in the 21(st) century: Biological and related challenges. Eur. J. Lipid Sci. Technol. 109, 296-306. doi:10.1002/ejlt.200600229

Naher, L., Tan, S.G., Ho, C.L., Yusuf, U.K., Ahmad, S.H., Abdullah, F., 2012. mRNA Expression of EgCHI1, EgCHI2, and EgCHI3 in Oil Palm Leaves (Elaeis guineesis Jacq.) after Treatment with Ganoderma boninense Pat. and Trichoderma harzianum Rifai. Sci. World J. doi:10.1100/2012/647504

Najera, A., Simonetti, J.A., 2010. Can oil palm plantations become bird friendly? Agrofor. Syst. 80, 203-209. doi:10.1007/s10457-010-9278-y

Najmie, M.M.K., Khalid, K., Sidek, A.A., Jusoh, M.A., 2011. Density and Ultrasonic Characterization of Oil Palm Trunk Infected by Ganoderma Boninense Disease. Meas. Sci. Rev. 11, 160-164. doi:10.2478/v10048-011-0026-X

Nasir, N., 2005. Diseases caused by Ganoderma spp. on perennial crops in Pakistan. Mycopathologia 159, 119-121. doi:10.1007/s11046-004-4433-5

Navia, M., Romero, H.M., Rodriguez, J., Velez, D.C., Martinez, G., 2011. Molecular identification of microorganisms associated with oil palm bud rot disease. Phytopathology 101, S254-S255.

Ngee, P.-S., 2002. Colony characterization of a mound-building subterranean termite, Globitermes sulphureus (Isoptera: Termitidae) using modified single-mark recapture technique. Sociobiology 40, 525-532.

Norris, R.F., Caswell-Chen, E.P., Kogan, M., 2003. Concepts in Integrated Pest Management. Prentice Hall.

Ntsefong, G.N., Ebongue, G.F.N., Paul, K., Martin, B.J., Emmanuel, Y., B., N.H., Gervais, B.E., Galdima, M., Bienvenu, A., 2012a. Control Approaches against Vascular Wilt Disease of Elaeis guineensis Jacq. Caused by Fusarium oxysporum f. sp. elaeidis. J. Biol. Life Sci. 3. doi:10.5296/jbls.v3i1.992

Ntsefong, G.N., Ngando Ebongue, G.F., Paul, K., Martin, B.J., Emmanuel, Y., Ngalle Hermine, B., Gervais, B.E., Galdima, M., Bienvenu, A., 2012b. Control Approaches against Vascular Wilt Disease of Elaeis guineensis Jacq. Caused by Fusarium oxysporum f. sp. elaeidis. J. Biol. Life Sci. JBLS 3, 160-173. doi:10.5296/jbls.v3i1.992

Nusaibah, S.A., Akmar, S.N.A., Pauzi, M.Z., Idris, A.S., Sariah, M., 2011. Detection Of Phytosterols In Ganoderma Boninense-Infected Oil Palm Seedlings Through Gc-Ms Analysis. J. Oil Palm Res. 23, 1069-1077.

Obuekwe, C., Osagie, I., 1989. Morphological-Changes in Infected Wilt-Resistant and WiltSusceptible Oil Palm Progenies and Hydrolytic Enzyme-Activities Associated with the Fusarium-Oxysporum F Sp Elaeidis Pathogens. Oleagineux 44, 393-402.

Oehlschlager, A.C., Chinchilla, C., Castillo, G., Gonzalez, L., 2002a. Control of red ring disease by mass trapping of Rhynchophorus palmarum (Coleoptera : Curculionidae). Fla. Entomol. 85, 507-513. doi:10.1653/0015-4040(2002)085[0507:CORRDB]2.0.CO;2

Oehlschlager, A.C., Chinchilla, C., Castillo, G., Gonzalez, L., 2002b. Control of red ring disease by mass trapping of Rhynchophorus palmarum (Coleoptera : Curculionidae). Fla. Entomol. 85, 507-513. doi:10.1653/0015-4040(2002)085[0507:CORRDB]2.0.CO;2

Oehlschlager, A.C., Chinchilla, C.M., Gonzalez, L.M., Jiron, L.F., Mexzon, R., Morgan, B., 1993. Development of a pheromone-based trapping system for Rhynchophorus palmarum (Coleoptera: Curculionidae). J. Econ. Entomol. 86, 1381-1392. 
Oritsejafor, J.J., 1986. Carbon and nitrogen nutrition in relation to growth and sporulation of Fusarium oxysporum f.sp. elaeidis. Trans. Br. Mycol. Soc. 87, 519-524.

doi:10.1016/S0007-1536(86)80092-4

Osei, K., Addico, R., Nafeo, A., Edu-Kwarteng, A., Agyemang, A., Danso, Y., Sackey-Asante, J., 2011. Effect of some organic waste extracts on hatching of Meloidogyne incognita eggs. Afr. J. Agric. Res. 6, 2255-2259.

Oviasogie, P.O., Aisueni, N.O., Brown, G.E., 2010a. Oil palm composted biomass: A review of the preparation, utilization, handling and storage. Afr. J. Agric. Res. 5, 1553-1571.

Oviasogie, P.O., Aisueni, N.O., Brown, G.E., 2010b. Oil palm composted biomass: A review of the preparation, utilization, handling and storage. Afr. J. Agric. Res. 5, 1553-1571.

Parra, E., Pena, J., Esparza, D., Labarca, M., 2009. Evaluation of organics substratum and also in combination with insecticide to capture Opsiphanes cassina F. adults in an oil palm (Elaeis guineensis Jacq.) plantation in Zulia state, Venezuela. Rev. Fac. Agron. Univ. Zulia 26, 455-469.

Paterson, R.R.M., 2007. Ganoderma disease of oil palm-A white rot perspective necessary for integrated control. Crop Prot. 26, 1369-1376. doi:10.1016/j.cropro.2006.11.009

Paterson, R.R.M., Moen, S., Lima, N., 2009a. The Feasibility of Producing Oil Palm with Altered Lignin Content to Control Ganoderma Disease. J. Phytopathol. 157, 649-656. doi:10.1111/j.1439-0434.2009.01553.x

Paterson, R.R.M., Moen, S., Lima, N., 2009b. The Feasibility of Producing Oil Palm with Altered Lignin Content to Control Ganoderma Disease. J. Phytopathol. 157, 649-656. doi:10.1111/j.1439-0434.2009.01553.x

Paterson, R.R.M., Moen, S., Lima, N., 2009c. The Feasibility of Producing Oil Palm with Altered Lignin Content to Control Ganoderma Disease. J. Phytopathol. 157, 649-656. doi:10.1111/j.1439-0434.2009.01553.x

Paterson, R.R.M., Sariah, M., Lima, N., 2013. How will climate change affect oil palm fungal diseases? Crop Prot. 46, 113-120. doi:10.1016/j.cropro.2012.12.023

Persey, S., Anhar, S., 2010. Biodiversity Information for Oil Palm.

Philippe, R., 1993. Study Of Pest Incidence On Female Oil Palm Inflorescences In West-Africa. Oleagineux 48, 389-405.

Philippe, R., Diarrassouba, S., 1979. Method of control of Coelaenomenodera by introduction of systemic insecticide into the oil palm trunk. Oleagineux 34, 229-233.

Pierre, E.M., Idris, A.H., 2013. Studies on the predatory activities of Oecophylla smaragdina (Hymenoptera: Formicidae) on Pteroma pendula (Lepidoptera: Psychidae) in oil palm plantations in Teluk Intan, Perak (Malaysia). Asian Myrmecol. 5, 163-176.

Pilotti, C.A., 2005. Stem rots of oil palm caused by Ganoderma boninense: Pathogen biology and epidemiology. Mycopathologia 159, 129-137. doi:10.1007/s11046-004-4435-3

Ploetz, R.C., 2006. Fusarium-induced diseases of tropical, perennial crops. Phytopathology 96, 648-652. doi:10.1094/PHYTO-96-0648

Poorjavad, N., Goldansaz, S.H., Avand-Faghih, A., 2009a. Response of the red palm weevil Rhynchophorus ferrugineus to its aggregation pheromone under laboratory conditions. Bull. Insectology 62, 257-260.

Poorjavad, N., Goldansaz, S.H., Avand-Faghih, A., 2009b. Response of the red palm weevil Rhynchophorus ferrugineus to its aggregation pheromone under laboratory conditions. Bull. Insectology 62, 257-260.

Potineni, K., Saravanan, L., 2013. Natural enemies of oil palm defoliators and their impact on pest population. Pest Manag. Hortic. Ecosyst. 19, 179-184. 
PRENDERGAST, A.G., 1957. Observations on the epidemiology of vascular wilt disease of the Oil Palm (Elaeis guineensis, Jacq.). J. West Afr. Inst. Oil Palm Res. 2, 148-175 .

Priwiratama, H., Susanto, A., others, 2014. Utilization of fungi for the biological control of insect pests and Ganoderma disease in the Indonesian oil palm industry. J. Agric. Sci. Technol. A 4, 103-111.

Puan, C.L., Goldizen, A.W., Zakaria, M., Baxter, G.S., 2011. Understanding of relationships between ground cover and rat abundances: An integrative approach for management of the oil palm agroecosystem. Crop Prot. 30, 1263-1268. doi:10.1016/j.cropro.2011.05.025

Puan, C.L., Goldizen, A.W., Zakaria, M., Hafidzi, M.N., Baxter, G.S., 2011. Absence Of Differential Predation On Rats By Malaysian Barn Owls In Oil Palm Plantations. J. Raptor Res. 45, 71-78.

Rajendran, L., Kandan, A., Karthikeyan, G., Raguchander, T., Samiyappan, R., 2009. Early Detection Of Ganoderma Causing Basal Stem Rot Disease In Coconut Plantations. J. Oil Palm Res. 21, 627-635.

Ramle, M., Wahid, M. b., Norman, K., Glare, T. r., Jackson, T. a., 2005. The incidence and use of Oryctes virus for control of rhinoceros beetle in oil palm plantations in Malaysia. J. Invertebr. Pathol. 89, 85-90. doi:10.1016/j.jip.2005.02.009

Ramle Moslim, Norman Kamarudin, Mohd Basri Wahid, 2009. Pathogenicity of granule formulations of Metarhizium anisopliae against the larvae of the oil palm rhinoceros beetle, Oryctes rhinoceros (L.). J. Oil Palm Res. 21, 602-612.

Rankine, I., Fairhurst, T.H., 1999. Management of phosphorus, potassium and magnesium in mature oil palm. Better Crops Int. 13, 11.

Rees, R.W., Flood, J., Hasan, Y., Cooper, R.M., 2007. Effects of inoculum potential, shading and soil temperature on root infection of oil palm seedlings by the basal stem rot pathogen Ganoderma boninense. Plant Pathol. 56, 862-870. doi:10.1111/j.13653059.2007.01621.x

Rees, R.W., Flood, J., Hasan, Y., Potter, U., Cooper, R.M., 2009. Basal stem rot of oil palm (Elaeis guineensis); mode of root infection and lower stem invasion by Ganoderma boninense. Plant Pathol. 58, 982-989. doi:10.1111/j.1365-3059.2009.02100.x

Renard, J., 1979a. Vascular Wilt Disease (Fusarium) In The Palm Oil - Diagnosis On The Plantation Control Methods. Oleagineux 34, 59-63.

Renard, J., 1979b. Vascular Wilt Disease (Fusarium) In The Palm Oil - Diagnosis On The Plantation Control Methods. Oleagineux 34, 59-63.

Renard, J., Quillec, G., 1984. Destructive Diseases Of Oil Palm In Africa And South-America. Oleagineux 39, 57-67.

Renard, J., Quillec, G., 1979. Diseases And Anomalies Of The Oil Palm In The Nursery. Oleagineux 34, 331-337.

Renard, J.L., Franqueville, H. de, 1991. Effectiveness of crop techniques in the integrated control of oil palm vascular wilt. Oléagineux 46, 255-265.

Reyes, A., Cruz, M., Genty, P., 1988. Use Of The Root Absorption Technique To Control Oil Palm Pests. Oleagineux 43, 363-370.

Ribeiro, R.C., Lemos, W.D.P., Castro, A.A.D., Poderoso, J.C.M., Serrão, J.E., Zanuncio, J.C., 2013. Trichospilus diatraeae (Hymenoptera: Eulophidae): A Potential Biological Control Agent of Lepidopteran Pests of Oil Palm in the Brazilian Amazon. Fla. Entomol. 96, 676678. doi:10.1653/024.096.0245

Ribeiro, R.C., Lemos, W.P., Bernardino, A.S., Buecke, J., Mueller, A.A., 2010. First Occurrence of Alcaeorrhynchus grandis (Dallas) (Hemiptera: Pentatomidae) Preying on Defoliating 
Caterpillars of Oil Palm in the State of Para, Brazil. Neotrop. Entomol. 39, 131-132. doi:10.1590/S1519-566X2010000100018

Ricklefs, R.E., Schluter, D., 1993. Species Diversity in Ecological Communities: Historical and Geographical Perspectives. University of Chicago Press.

Rutherford, M.A., Flood, J., 1996. Vascular wilt diseases of tropical crops caused by Fusarium oxysporum. British Crop Protection Council, Farnham.

Saenz A, A., Olivares, W., 2008. Speed of movement of first instar larvae of Sagalassa valida (Lepidoptera : Glyphipterigidae). Rev. Colomb. Entomol. 34, 57-61.

Samiyappan, R., Bhaskaran, R., Rethinam, P., 1996. Diagnosis for early detection of Ganoderma diseases in perennial crops: Approaches and prospects. Z. Pflanzenkrankh.

Pflanzenschutz-J. Plant Dis. Prot. 103, 85-93.

Sanderson, F.R., 2005. An insight into spore dispersal of Ganoderma boninense on oil palm. Mycopathologia 159, 139-141. doi:10.1007/s11046-004-4436-2

Sasaerila, Y., Gries, R., Gries, G., Khaskin, G., King, S., Boo, T.C., 2000. Decadienoates: sex pheromone components of nettle caterpillars Darna trima and D. bradleyi. J. Chem. Ecol. 26, 1969-1981.

Savilaakso, S., Garcia, C., Garcia-Ulloa, J., Ghazoul, J., Groom, M., Guariguata, M.R., Laumonier, Y., Nasi, R., Petrokofsky, G., Snaddon, J., Zrust, M., 2014. Systematic review of effects on biodiversity from oil palm production. Environ. Evid. 3, 4. doi:10.1186/2047-2382-3-4

Sewify, G.H., Belal, M.H., Al-Awash, S.A., 2009a. Use of the Entomopathogenic Fungus, Beauveria bassiana for the Biological Control of the Red Palm Weevil, Rhynchophorus ferrugineus Olivier. Egypt. J. Biol. Pest Control 19, 157-163.

Sewify, G.H., Belal, M.H., Al-Awash, S.A., 2009b. Use of the Entomopathogenic Fungus, Beauveria bassiana for the Biological Control of the Red Palm Weevil, Rhynchophorus ferrugineus Olivier. Egypt. J. Biol. Pest Control 19, 157-163.

Sewify, G.H., Belal, M.H., Al-Awash, S.A., 2009c. Use of the Entomopathogenic Fungus, Beauveria bassiana for the Biological Control of the Red Palm Weevil, Rhynchophorus ferrugineus Olivier. Egypt. J. Biol. Pest Control 19, 157-163.

Sewify, G.H., Belal, M.H., Al-Awash, S.A., 2009d. Use of the Entomopathogenic Fungus, Beauveria bassiana for the Biological Control of the Red Palm Weevil, Rhynchophorus ferrugineus Olivier. Egypt. J. Biol. Pest Control 19, 157-163.

Shafie, N.J., Sah, S.A.M., Latip, N.S.A., Azman, N.M., Khairuddin, N.L., 2011. Diversity pattern of bats at two contrasting habitat types along Kerian River, Perak, Malaysia. Trop. Life Sci. Res. 22, 13-22.

Shanta, P., 1970. Oil-Palm (Elaeis-Guineensis Jacq) A Natural Host Of Root (Wilt) Disease Pathogen Of Coconut. Curr. Sci. 39, 260-.

Siddiquee, S., Yusuf, U.K., Hossain, K., Jahan, S., 2009a. In vitro studies on the potential Trichoderma harzianum for antagonistic properties against Ganoderma boninense. J. Food Agric. Environ. 7, 970-976.

Siddiquee, S., Yusuf, U.K., Hossain, K., Jahan, S., 2009b. In vitro studies on the potential Trichoderma harzianum for antagonistic properties against Ganoderma boninense. J. Food Agric. Environ. 7, 970-976.

Singh, G., 1991. Ganoderma - the scourge of oil palms in the coastal areas. The Planter 67, 421444. 
Singh, R.P., Ibrahim, M.H., Esa, N., Iliyana, M.S., 2010. Composting of waste from palm oil mill: a sustainable waste management practice. Rev. Environ. Sci. Biotechnol. 9, 331344. doi:10.1007/s11157-010-9199-2

Sithanantham, S., Ballal, C.R., Jalali, S.K., Bakthavatsalam, N., n.d. Biological Control of Insect Pests Using Egg Parasitoids.

Sodhi, N.S., Koh, L.P., Clements, R., Wanger, T.C., Hill, J.K., Hamer, K.C., Clough, Y., Tscharntke, T., Posa, M.R.C., Lee, T.M., 2010. Conserving Southeast Asian forest biodiversity in human-modified landscapes. Biol. Conserv. 143, 2375-2384. doi:10.1016/j.biocon.2009.12.029

Solulu, T.M., Simpson, S.J., Kathirithamby, J., 1998. The effect of strepsipteran parasitism on a tettigoniid pest of oil palm in Papua New Guinea. Physiol. Entomol. 23, 388-398. doi:10.1046/j.1365-3032.1998.00095.x

Sundram, S., Abdullah, F., Ahmad, Z.A.M., Yusuf, U.K., 2008a. Efficacy of single and mixed treatments of Trichoderma harzianum as biocontrol agents of Ganoderma basal stem rot of oil palm. J. Oil Palm Res. 20, 470-483.

Sundram, S., Abdullah, F., Ahmad, Z.A.M., Yusuf, U.K., 2008b. Efficacy of single and mixed treatments of Trichoderma harzianum as biocontrol agents of Ganoderma basal stem rot of oil palm. J. Oil Palm Res. 20, 470-483.

Sundram, S., Meon, S., Abu Seman, I., Othman, R., 2011. Symbiotic Interaction of Endophytic Bacteria with Arbuscular Mycorrhizal Fungi and Its Antagonistic Effect on Ganoderma boninense. J. Microbiol. 49, 551-557. doi:10.1007/s12275-011-0489-3

Suryanto, D., Wibowo, R.H., Siregar, E.B.M., Munir, E., 2012a. A possibility of chitinolytic bacteria utilization to control basal stems disease caused by Ganoderma boninense in oil palm seedling. Afr. J. Microbiol. Res. 6, 2053-2059. doi:10.5897/AJMR11.1343

Suryanto, D., Wibowo, R.H., Siregar, E.B.M., Munir, E., 2012b. A possibility of chitinolytic bacteria utilization to control basal stems disease caused by Ganoderma boninense in oil palm seedling. Afr. J. Microbiol. Res. 6, 2053-2059. doi:10.5897/AJMR11.1343

Susanto, A., Sudharto, P.S., Purba, R.Y., 2005a. Enhancing biological control of basal stem rot disease (Ganoderma boninense) in oil palm plantations. Mycopathologia 159, 153-157. doi:10.1007/s11046-004-4438-0

Susanto, A., Sudharto, P.S., Purba, R.Y., 2005b. Enhancing biological control of basal stem rot disease (Ganoderma boninense) in oil palm plantations. Mycopathologia 159, 153-157. doi:10.1007/s11046-004-4438-0

Susanto, A., Sudharto, P.S., Purba, R.Y., 2005c. Enhancing biological control of basal stem rot disease (Ganoderma boninense) in oil palm plantations. Mycopathologia 159, 153-157. doi:10.1007/s11046-004-4438-0

Susanto, A., Sudharto, P.S., Purba, R.Y., 2005d. Enhancing biological control of basal stem rot disease (Ganoderma boninense) in oil palm plantations. Mycopathologia 159, 153-157. doi:10.1007/s11046-004-4438-0

Suwandi, Akino, S., Kondo, N., 2012. Common Spear Rot of Oil Palm in Indonesia. Plant Dis. 96, 537-543. doi:10.1094/PDIS-08-10-0569

Talledo Albujar, M.J., Morales Ruiz, S.S., Trinidad Chipana, E., Arevalo Zelada, J., Trelles Di Lucca, A., Montoya Piedra, Y., 2010. Description of two genotypes of Phytomonas associated to oil palm diseases in Peru: Marchites Sorpresiva and a new disease manifestation-Marchites Lenta. Phytopathology 100, S125-S125.

Tinoco, R.S., Ribeiro, R.C., Tavares, M.T., Vilela, E.F., Lemos, W.D.P., Zanuncio, J.C., 2012. Brachymeria Spp. (Hymenoptera: Chalcididae) Parasitizing Pupae Of Hersperidae And 
Nymphalidae (Lepidoptera) Pests Of Oil Palm In The Brazilian Amazonian Region. Fla. Entomol. 95, 788-789.

Torres, G.A., Sarria, G.A., Varon, F., Coffey, M.D., Elliott, M.L., Martinez, G., 2010. First Report of Bud Rot Caused by Phytophthora palmivora on African Oil Palm in Colombia. Plant Dis. 94, 1163-1163. doi:10.1094/PDIS-94-9-1163A

Tscharntke, T., Bommarco, R., Clough, Y., Crist, T.O., Kleijn, D., Rand, T.A., Tylianakis, J.M., Nouhuys, S. van, Vidal, S., 2007. Conservation biological control and enemy diversity on a landscape scale. Biol. Control 43, 294-309. doi:10.1016/j.biocontrol.2007.08.006

Turner, P., 1971. Recent Survey Of Oil Palm Diseases In Indonesia. Fao Plant Prot. Bull. 19, 49-. Turner, P., 1969. Pests And Diseases Of Oil Palm In Thailand. Fao Plant Prot. Bull. 17, $107-$. Turner, P., 1965. Incidence Of Ganoderma Disease Of Oil Palms In Malaya And Its Relation. Ann. Appl. Biol. 55, 417-. Doi:10.1111/J.1744-7348.1965.Tb07954.X

Turner, P.D., 1981. Oil palm diseases and disorders. xvii + 280 pp.

Turner, P.D., 1967a. Evaluation of Fungicides for Use against Marasmius Palmivorus On Oil Palms. Exp. Agric. 3, 129-135. doi:10.1017/S0014479700021906

Turner, P.D., 1967b. Evaluation of Fungicides for Use against Marasmius Palmivorus On Oil Palms. Exp. Agric. 3, 129-135. doi:10.1017/S0014479700021906

Utomo, C., Niepold, F., 2000. Development of diagnostic methods for detecting Ganodermainfected oil palms. J. Phytopathol.-Phytopathol. Z. 148, 507-514. doi:10.1046/j.14390434.2000.00478.x

Utomo, C., Werner, S., Niepold, F., Deising, H.B., 2005. Identification of Ganoderma, the causal agent of basal stem rot disease in oil palm using a molecular method. Mycopathologia 159, 159-170. doi:10.1007/s11046-004-4439-z

Vadamalai, G., Hanold, D., Rezaian, M.A., Randles, J.W., 2006. Variants of Coconut cadangcadang viroid isolated from an African oil palm (Elaies guineensis Jacq.) in Malaysia. Arch. Virol. 151, 1447-1456. doi:10.1007/s00705-005-0710-y

Vadamalai, G., Perera, A.A.F.L.K., Hanold, D., Rezaian, M.A., Randles, J.W., 2009. Detection of Coconut cadang-cadang viroid sequences in oil and coconut palm by ribonuclease protection assay. Ann. Appl. Biol. 154, 117-125. doi:10.1111/j.1744-7348.2008.00278.x

Van de Lande, H.L., Zadoks, J.C., 1999. Spatial patterns of spear rot in oil palm plantations in Surinam. Plant Pathol. 48, 189-201.

Vandelande, H., 1993. Spatiotemporal Analysis Of Spear Rot And Marchitez-Sorpresiva In African Oil Palm In Surinam. Neth. J. Plant Pathol. 99, 129-138.

Vanslobbe, W., 1983. Control Of Castnia-Daedalus, A Major Pest Of Oil Palm In Suriname. Trop. Agric. 60, 172-174.

Wardlaw, C., 1948. Vascular Wilt Disease Of Oil Palms In Nigeria. Nature 162, 850-851. Doi:10.1038/162850c0

Wardlaw, C., 1946. A Wilt Disease Of The Oil Palm. Nature 158, 56-56. Doi:10.1038/158056a0

Wibawa, W., Mohamad, R.B., Omar, D., Zain, N.M., Puteh, A.B., Awang, Y., 2010a. Comparative impact of a single application of selected broad spectrum herbicides on ecological components of oil palm plantation. Afr. J. Agric. Res. 5, 2097-2102.

Wibawa, W., Mohamad, R.B., Omar, D., Zain, N.M., Puteh, A.B., Awang, Y., 2010b. Comparative impact of a single application of selected broad spectrum herbicides on ecological components of oil palm plantation. Afr. J. Agric. Res. 5, 2097-2102.

Wood, B.J., 2002. Pest control in Malaysia’s perennial crops: a half century perspective tracking the pathway to integrated pest management. Integr. Pest Manag. Rev. 7, 173-190. 
Wood, B.J., 1971. Development of integrated control programs for pests of tropical perennial crops in Malaysia, in: Biological Control. Springer, pp. 422-457.

Wood, B.J., 1969. Studies on the effect of ground vegetation on infestations of Oryctes rhinoceros (L.) (Col., Dynastidae) in young oil palm replantings in Malaysia. Bull. Entomol. Res. 59, 85-96. doi:10.1017/S0007485300003059

Wood, B.J., 1968. Pests of oil palms in Malaysia and their control. Cambridge Univ Press.

Wood, B.J., Fee, C.G., 2003. A critical review of the development of rat control in Malaysian agriculture since the 1960s. Crop Prot. 22, 445-461. doi:10.1016/S0261-2194(02)00207-7

Wood, B.J., Liau, S.S., 1984. A long-term study of Rattus tiomanicus populations in an oil palm plantation in Johore, Malaysia: II. Recovery from control and economic aspects. J. Appl. Ecol. 465-472.

Wood, B.J., Liau, S.S., 1978. Rats as agricultural pests in Malaysia and the tropics. The Planter 54, 580-599.

Wood, B.J., Liau, S.S., Knecht, J.C.X., 1974a. Trunk injection of systemic insecticides against the bagworm, Metisa plana (Lepidoptera: Pyralidae) on oil palm. Oleagineux 29, 499505; es xxxi.

Wood, B.J., Liau, S.S., Knecht, J.C.X., 1974b. Trunk injection of systemic insecticides against the bagworm, Metisa plana (Lepidoptera: Pyralidae) on oil palm. Oleagineux 29, 499505; es xxxi.

Young, E.C., 1986. The Rhinoceros Beetle Project: History and review of the research programme. Agric. Ecosyst. Environ. 15, 149-166.

Zeddam, J., Philippe, R., Veyrunes, J., Fediere, G., Mariau, D., Bergoin, M., 1990. Study of the Ribovirus of Latoia viridissima Holland, a palm pest in West Africa - characterization diagnosis - serology sand epidemiologic monitoring. Oleagineux 45, 493-500.

Zeddam, J., Philippe, R., Veyrunes, J., Fediere, G., Mariau, D., Bergoin, M., 1990. Study Of The Ribovirus Of Latoia Viridissima Holland, A Palm Pest In West Africa - Characterization - Diagnosis - Serology Sand Epidemiologic Monitoring. Oleagineux 45, 493-500.

Zeddam, J.L., Cruzado, J.A., Rodriguez, J.L., Ravallec, M., 2003a. A new nucleopolyhedrovirus from the oil-palm leaf-eater Euprosterna elaeasa (Lepidoptera : Limacodidae): preliminary characterization and field assessment in Peruvian plantation. Agric. Ecosyst. Environ. 96, 69-75. doi:10.1016/S0167-8809(03)00034-3

Zeddam, J.L., Cruzado, J.A., Rodriguez, J.L., Ravallec, M., Subilete, E.C., 2003b. A cypovirus from the South American oil-palm pest Norape argyrrhorea and its potential as a microbial control agent. Biocontrol 48, 101-112. doi:10.1023/A:1021234700472

Zeddam, J.L., Cruzado, J.A., Rodriguez, J.L., Ravallec, M., Subilete, E.C., 2003c. A cypovirus from the South American oil-palm pest Norape argyrrhorea and its potential as a microbial control agent. Biocontrol 48, 101-112. doi:10.1023/A:1021234700472

Zelazny, B., Lolong, A., Pattang, B., 1992a. Oryctes rhinoceros (Coleoptera: Scarabaeidae) populations suppressed by a baculovirus. J. Invertebr. Pathol. 59, 61-68. doi:10.1016/0022-2011(92)90112-H

Zelazny, B., Lolong, A., Pattang, B., 1992b. Oryctes rhinoceros (Coleoptera: Scarabaeidae) populations suppressed by a baculovirus. J. Invertebr. Pathol. 59, 61-68. doi:10.1016/0022-2011(92)90112-H 
Appendix 1. Search keywords used in the ISI Web of Science advanced search (WOS)

I. First part, general information on pest-disease-biocontol:

TS=(oil Palm*) AND TS $=($ pest*)

TS $=($ oil Palm*) AND TS $=($ disease*)

TS=(oil Palm*) AND TS=(biological control*)

II. Second part, influencing factors of pest-disease-biocontrol:

1. The Landscape type surrounding the plantation

TS=(“oil*palm*”) AND TS=(forest* OR natur* OR habitat* OR semi-natural OR area* OR ecosystem* OR plantation* OR landscape OR configuration OR surrounding OR cover* OR old-growth OR young OR secondary OR natural OR buffer zone* OR protect* OR remnant OR patch* OR adjacent OR fragment* OR adjoining OR corridor* OR distance OR native OR proximity OR size OR inside OR nearest OR edge* OR extensive OR nearby OR retaining OR log* OR large OR continuous OR isolate* OR surround* OR contiguous) AND TS=(“species richness" OR "species abundance” OR "species composition” OR "species diversity”) AND TS=(rescue OR spillover OR effect* OR across OR turnover OR matrix OR edge OR hospitable)

2. The oil palm understory vegetation

TS=(“oil*palm*”) AND TS=(vegetation OR complexit* OR structural Or ground Or vegetation* OR ground cover* OR beneath OR understory OR matrix* OR cover* OR crop* OR bare OR sparse OR dense OR local Or characteristic* OR epiphytic* OR layer* OR undergrowth OR tree* OR undergrowth OR retaining) AND TS=(species richness OR species abundance OR species composition OR species diversity)

3. The amount and quality of pesticide applications

TS=(“oil*palm*”) AND TS=(herbicide* OR pesticide* OR chemical* OR compound* OR insecticide* OR fungicide*) AND TS=(excessive OR use OR dosage* OR rate* OR inject* OR recommended OR dose* OR systemic OR formulation* OR holes OR bored* OR quantit* OR residu* OR activity OR left OR accumulation OR drift OR misdirected OR spraying OR detectable OR phytotoxic OR bound) AND TS=(microbial OR microorganism* OR soil fertility OR fungal OR pest* OR environmental OR predator* OR parasite* OR beneficial OR insect* OR non-target OR weed OR disease) AND TS=(tolerance OR susceptible OR resistant* OR inhibit* OR outbreak* OR detected OR persist* OR hazard* OR toxicity OR impact OR mortality OR leaching OR damage* OR threat* OR adverse OR effect* OR effect* OR infestation* OR control*)

4. The fertilizer applications

TS=(“oil*palm*”) AND TS=(amendment OR compost* OR fertilizer* OR potassium OR nutritional OR carbon OR nutrient OR phosphate OR muriate of potash OR urea OR sodium OR nitrogen OR magnesium OR phosphate OR zinc OR iron OR waste* OR milll effluent* OR empty fruit bunch* OR K fertilizer OR manure OR sucrose OR CjN) AND TS=(status OR concentration* OR level* OR analys* OR content* OR ratio*) AND TS=(enhanc* OR increase* OR format* reduc* OR promot* OR low OR associate* OR suppress* OR control* OR secret* OR elevat OR effect*) AND TS=(fung* OR macroconidial OR chlamydospor* OR symptom* OR diseas* OR incidenc* OR ganoderma OR antagonist* OR trichoderma OR wilt* OR pathogen* OR microb* OR beneficial OR organism*) 
Appendix 2. List of oil palm pest-disease-biocontrol including their topic studies.

\begin{tabular}{|c|c|c|}
\hline Oil Palm Pests & Oil Palm Diseases & Biocontrol Methods \\
\hline $\begin{array}{l}\text { Trunk Borer } \\
\text { - Rhynchophorus ferrugineus, palmarum [digestive fluid, } \\
\text { association with red ring and bud rot disease, pheromone } \\
\text { trapping, oil dispersion formulation as a drench, biocontrol } \\
\text { (Parasitoid: Paratheresia menezesi \& Billaea rhynchophorae; } \\
\text { entomopathogenic Fungus: Beauveria bassiana), antifeedant } \\
\text { activity, and synthetic insecticide. } \\
\text { - Oryctes rhinoceros, monocero (pheromone and palm material } \\
\text { trapping, biocontrol (baculovirus, Oryctes virus and } \\
\text { Metarhizium anisopliae), and Agronomical techniques (cover } \\
\text { crop). } \\
\text { - Calyptocephalella gerstaeckeri (Bionomics Data and } \\
\text { Descriptions). } \\
\text { Number of References : 28 } \\
\text { (Allou et al., 2006, 2006; Bergou and Hillery, 2013; Chinchilla et } \\
\text { al., 1990; Chinchilla and Richardson, 1990; Córdova-Ballona and } \\
\text { Sánchez-Soto, 2008; Effraim, 1996; Gomes De Oliveira et al., } \\
\text { 2011; Hallett et al., 1999b, 1999c; Alois M. Huger, 2005; } \\
\text { MOHAN and PILLAI, 1993; Moslim et al., 2011a, 2011b, 2010, } \\
\text { 2009, 2007; MOURA et al., 1993; Moura et al., 2006; } \\
\text { Oehlschlager et al., 2002a, 2002b; Poorjavad et al., 2009b; Ramle } \\
\text { et al., 2005; Ramle Moslim et al., 2009; Sewify et al., 2009c, } \\
\text { 2009d; Wood, 1969; Zelazny et al., 1992b) }\end{array}$ & 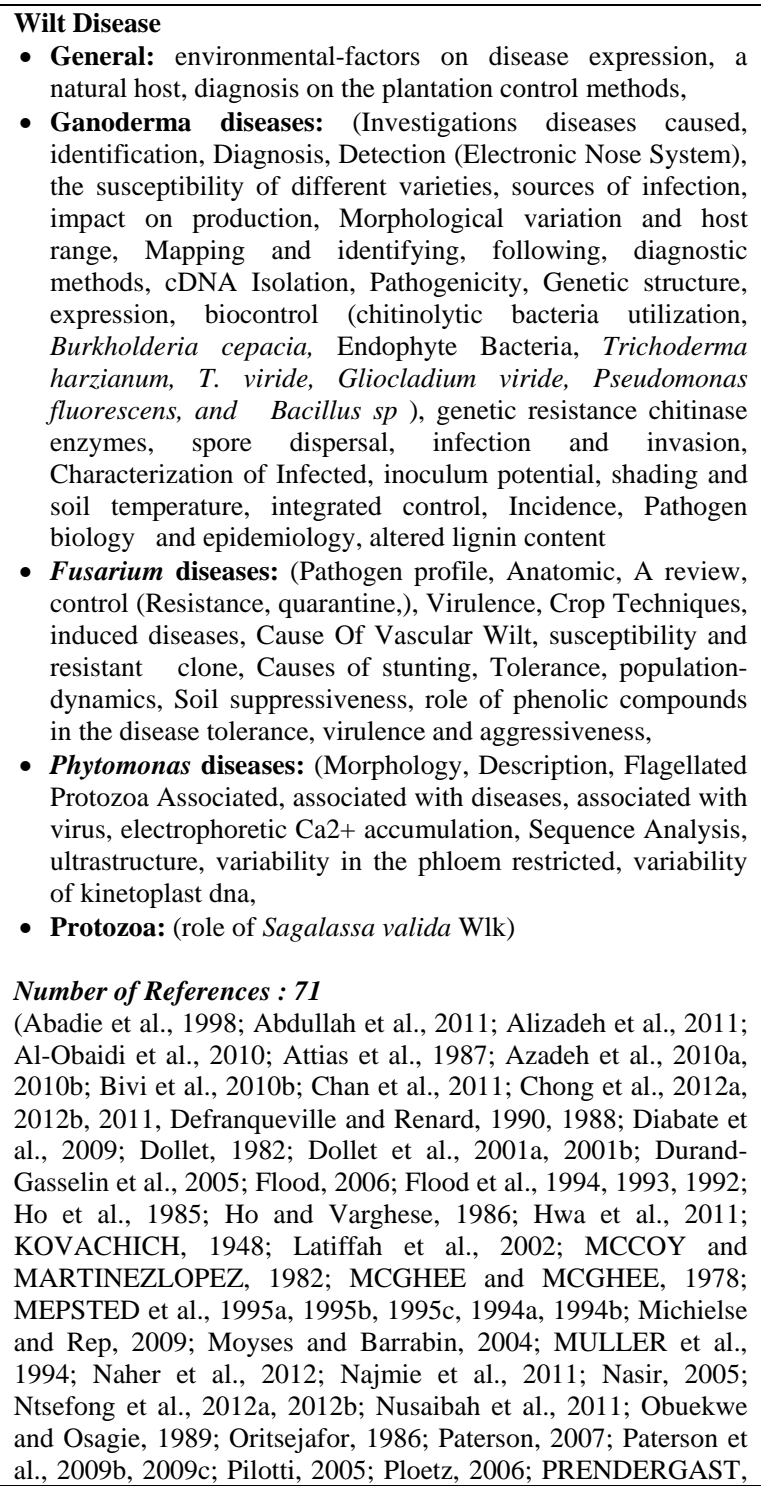 & $\begin{array}{l}\text { Trunk Borer } \\
\text { - Coleopterous, Biocontrol agents (Palmistichus elaeisis and } \\
\text { P. ixtlilxochitli (Girault) comb. n); Topics (a new species } \\
\text { parasitic on key pests of oil palm) } \\
\text { - Oryctes sp, Agents (Oryctes baculovirus, Palmistichus } \\
\text { elaeisis, P. ixtlilxochitli, parasitoids, Metarhizium } \\
\text { anisopliae, Beauveria bassiana); Topic study (detection, } \\
\text { identification, implementation in biocontrol, molecular } \\
\text { approaches in the assessment of biocontrol agents, } \\
\text { application of powder formulation of biocontrol agents, } \\
\text { pathogenicity of granule formulations of biocontrol, trap } \\
\text { for the auto dissemination of biocontrol agents, the } \\
\text { incidence and use of biocontrol agent). } \\
\text { - Rhynchophorus sp, Agents (Paratheresia menezesi, } \\
\text { Billaea rhynchophorae, Beauveria bassiana); Topics } \\
\text { (effectiveness of parasitoid, natural efficiency of } \\
\text { parasitism, use of entomopathogenic biocontrol agents). } \\
\text { - Sagalassa valida, Agent (Steinernema carpocapsae); } \\
\text { Topics (distribution of entomopathogenic agents, } \\
\text { searching capacity of the biocontrol agent). } \\
\\
\text { Number of References : 12 } \\
\text { (Aponte and Olivares, 2008; A. M. Huger, 2005; Kanga et al., } \\
\text { 2012; KOUASSI et al., 1991; MOHAN and PILLAI, 1993; } \\
\text { Moslim et al., 2011a, 2011b, 2007; MOURA et al., 1993; } \\
\text { Moura et al., 2006; Ramle et al., 2005, 2005; Sewify et al., } \\
\text { 2009d; Zelazny et al., 1992b) }\end{array}$ \\
\hline
\end{tabular}


1957; Rajendran et al., 2009; Rees et al., 2009, 2007, RENARD,

1979a, 1979b, Rutherford and Flood, 1996, 1996; Samiyappan et

al., 1996; Sanderson, 2005; SHANTA, 1970; Siddiquee et al., 2009a, 2009b, Sundram et al., 2011, 2008a, 2008b, Suryanto et al., 2012a, 2012b, Susanto et al., 2005b, 2005c; Talledo Albujar et al., 2010; TURNER, 1965; Utomo et al., 2005; Utomo and Niepold, 2000; WARDLAW, 1948, 1946)

\section{Defoliator or leaf-eater}

- Limacodidae : Euprosterna elaeasa, Latoia viridissima, Sibine spp, Euprosterna elaeasa, Darna spp, and Setora nitens) (Biocontrol (Picornavirus, Nucleopolyhedrovirus, cypovirus and ribovirus, Alcaeorrhynchus grandis, $B$. thuringiensis, insectivorous birds, Atopomyrmex mocquerysi), sintetic pesticide)

- Bagworm : Metisa plana Walker and, Cremastopsyche pendula, Pteroma pendula and Mahasena corbetti (Pheromone trapping, Entomopathogenic Fungus

(Paecilomyces spp), infestation, interaction with natural enemies (Dolichogenidea metesae, Callimerus arcufer, an Sycanus dichotomus)

- Castnia Daedalus (Ecology and synthetic insecticide)

- Sagalassa valida (description, general control, speed of movement.

- Norape argyrrhorea (biocontrol agent: cypovirus) |

- Katydids : Tettigoniidae (biological contro (Stichotrema dallatorreanum)

\section{Number of References : 25}

(Abdullah et al., 2012; Austin, 1987; Bakeri et al., 2009; Basri et al., 1995; Cruz and Reyes, 1991; Fediere et al., 1990; Genty, 1977; Igbinosa, 1992, 1985, Kamarudin et al., 2010, 2010; Kamarudin and Wahid, 2010; Kenne et al., 2009; KOUASSI et al., 1991; Saenz A and Olivares, 2008; Sasaerila et al., 2000; VANSLOBBE, 1983; Wood et al., 1974b; ZEDDAM et al., 1990 Zeddam et al., 2003a)

\section{General disease}

fungal expression, destructive diseases, diseases and anomalies, diseases of oil palm, infestation, forest landscape to agricultural landscape, future prospects, insects carrying diseases,

investigations, oil palm composted biomass, biological-control of pseudotheraptus and related species, principal oil palm diseases, recent survey of oil palm diseases in indonesia

\section{Number of References : 17}

(Abdullah and Hezri, 2008; Aderungboye, 1977; Agodan, 1980; Douaho, 1984; Dzido et al., 1978; Genty, 1977; Hasan et al., 2005; Jollands, 1983; Julia, 1979; Lelong et al., 2010; MARIAU, 1993a; MEPSTED et al., 1995b; Murphy, 2007; Oviasogie et al., 2010b; Paterson et al., 2013; RENARD and QUILLEC, 1984 1979, 1979; Talledo Albujar et al., 2010; TURNER, 1971, 1971, 1969)

\section{Defoliator or leaf-eater}

- lepidopterous, Agents (P. elaeisis sp. n., and ixtlilxochitl (Girault) comb. n, insectivorous birds, Baculoviruses, Picornaviruses, beta nudaureliaviruses ); Topics (a new species parasitic on key pests of oil palm, birds defend oil palms from herbivorous insects, importance of the role of entomopathogenic viruses)

- Norape argyrrhorea, Agents (cypovirus); Topics (potentia as a microbial control agent)

- Euprosterna elaeasa, Agents (nucleopolyhedrovirus); Topics (Preliminary characterization and field assessment)

- Latoia viridissima, Agents (picornavirus, a nuclear polyhedrosis baculoviruses, ribovirus); Topics (Biocontrol method, Detection of the biocontrol agent in the pest, study of the ribovirus)

- Hersperidae and Nymphalidae, Agents (Brachymeria SPP); Topics (Parasitizing pupae)

- Brassolis sophorae, Opsiphanes invirae, and Sibine spp, Agents (Alcaeorrhynchus grandis); Topics (First Occurrence of the agent preying on defoliating caterpillars)

- Opsiphanes invirae, Brassolis sophorae, Eupalamides cyparissias, Agents (Trichospilus diatraeae \&

Margabandhu); Topics (a potential biological control agent of lepidopteran pests)

- Pteroma pendula, Agents (Paecilomyces carnet's and $P$ farinosus, flowering plants (C. cobanensis, Asystasia gangetica), ); Topics (efficacy of entomopathogenic agent, interactions of the pest and its natural enemies)

- Metisa plana, Agents (Cassia cobanensis/a leguminous nectar, Oecophylla smaragdina, Dolichogenidea metesae, Callimerus arcufer); Topics (interactions of the bagworm and its natural enemies in an oil palm plantation, studies on the predatory activities, Natural enemies and their impact on host population regulation)

- Coelaenomenodera elaeidis, Agents (); Topics (Chrysomelidae Coleoptera living off oil palm and coconut, and their parasitoids, larval parasites- introduction to a method of biocontrol)

- Tettigoniidae, Agents (Stichotrema dallatorreanum Hofeneder); Topics (novel biocontrol tools for oil paln 
General pest control (Pests and diseases of the oil palm (in Latin-America, West-Africa, Papua New Guinea, Southeast-Asia, and Thailand), Insect pests and insect-vectored diseases, pest incidence, general pest and control, recommended insecticides, Integrated Control)

Number of References : 21

(Agodan, 1980; Anonymous, 1981, 1978; Bianchi et al., 2006; Caudwell, 2000; Dewhurst, 2011; Douaho, 1984; Gitau et al., 2009; MARIAU, 1993b; MARIAU et al., 1991; MARIAU and GENTY, 1992; Martin et al., 2013; PHILIPPE, 1993; REYES et al., 1988; Sewify et al., 2009d; Sithanantham et al., n.d.;

TURNER, 1969; Wood, 2002, 1971, 1968)

\section{Virus disease}

Coconut cadang-cadang viroid (CCCVd), lethal 'ringspot', Fatal yellowing, RNA VIRUS-LIKE PARTICLES (extraction, detection, Characterization and Detection, associate with Phytomonas diseases, Variants)

\section{Number of References : 8}

(Beuther et al., 1992; Hanold and Randles, 1991; MARCHE et al., 1993; Mohammadi et al., 2010; Morales et al., 2002;

Vadamalai et al., 2009, 2006)

\section{Number of References : 11}

(Bakeri et al., 2009; Basri et al., 1995; Cruz and Reyes, 1991; Fediere et al., 1990; Kamarudin and Wahid, 2010; KOUASSI et al., 1991, 1991; MARIAU et al., 1978; MARIAU and DECHENON, 1990; Parra et al., 2009; Pierre and Idris, 2013; Ribeiro et al., 2010; Solulu et al., 1998; Tinoco et al., 2012; ZEDDAM et al., 1990; Zeddam et al., 2003a)

\section{Wilt diseas}

Ganoderma sp, Agent (chitinolytic bacteria utilization, Endophyte Bacteria, Trichoderma harzianum, Symbiotic Interaction of Endophytic Bacteria (Pseudomonas aeruginosa UPMP3 and Burkholderia cepacia UPMB3) with Arbuscular Mycorrhizal Fungi (Glomus intraradices UT126 and Glomus clarum BR152B ), the different oil palm varieties); Topics (Quantification and characterization of biocontrol agents, Control, the susceptibility of different oil palm varieties, use of biocontrol agents, In vitro studies on the potential biocontrol agents, Efficacy of single and mixed treatments of biocontrol agents, Symbiotic Interaction of biocontrol agent and their antagonistic effect. A possibility of a biocontrol agents, Enhancing biological control)

\section{Number of References : 9}

(Bivi et al., 2010a; Chong et al., 2012b; Durand-Gasselin et al., 2005; Paterson et al., 2009b; Siddiquee et al., 2009a; Sundram et al., 2011, 2008a, Suryanto et al., 2012a, 2012b, Susanto et al., 2005b, 2005c)

Mamalian : Rattus rattus diardii (Biological control (Tyto alba javanica, Sarcocystis singaporensis), ranging behaviour and habitat utilization, damage levels

\section{Number of References :5}

(Andru et al., 2013b; Buckle et al., 1997; Jakel et al., 1999; Wood and Liau, 1984)
Blast disease : Pythium splendens and Rhizoctonia lamellifera (role of Recilia mica Kramer, controlling, Control Improvement, prospects of breeding resistance)

\section{Number of References :5}

(Blaak, 1969; Defranqueville et al., 1991; Desmierdechenon, 1979; Desmierdechenon et al., 1977).

\section{General biocontro}

Pseudotheraptus, pests and disease, insect pests and insectvectored diseases of palms, diseases of oil palm Agents();

Topics (parasitoid, predator, preventive measures, Bacillus thuringiensis (Expression), Improved biocontrol, various intercrops , Integrated Control, regulating populations.

Biological-control of pseudotheraptus and related species, Biological-control of pseudotheraptus and related species,
laboratory investigations on fungicides and biological agents, entomological problems involved in replanting, what research into combating oil palm pest, potential as a microbial control agent

\section{Number of References : 8}

(Aderungboye, 1977; Dhileepan, 1991; Douaho, 1984; Gitau et al., 2009; Jollands, 1983; Lee et al., 2006; MARIAU et al., 1991; Wood, 1971)
Isoptera : Captotermes curvignathus, Globitermes sulphureus (biodiversity, Entomopathogenic Fungus (Metarhizium
Common spear rot (CSR) / Crown disease : Ceratocystis paradoxa (pathogen associated, Epistasis, unknown aetiology
Mammalia : Rat / Roden, Agents (Tyto alba javanica, Topics (Biological contro, 
anisopliae), termicidal plant extract (neem \& castor), colony characterization

Number of References : 3

(Hassall et al., 2006; Kon et al., 2012; Ngee, 2002)

\section{Leafhopper : Zophiuma butawengi, Zophiuma lobulata} (description of damage, biological control (hymenopterans Ooencyrtus sp \& Parastethynium maxwelli

\section{Number of References : 3}

(Catherine Wanjiru Gitau et al., 2011; Guerrieri et al., 2011;

Huber et al., 2011)

\section{Root Borer}

Meloidogyne incognita, Steinernema sp (organic extracts,

Searching capacity)

\section{Number of References : 2}

(Aponte and Olivares, 2008; Osei et al., 2011)

Bug :, Pleseobyrsa bicincta (biological study, synthetic insecticide)

Number of References : 1

(Mazariego-Arana et al., 2002b)

Avian : Acridotheres tristis, Corvus macrorhynchus, Corvus splendens, Centropus sinensis, Loriculus sp, Milvus migrans (Investigations)

Number of References : 1

(Dhileepan, 1989)

Stick insect : Eurycantha calcarata (description and egg

parasitoid nomenclatural (Anastatus Motschulsky)

Number of References : 1

(Gibson et al., 2012)

Colletotrichum gloeosporioides (Characterization and genetic

(Alvarez et al., 2012)
Number of References : 5

(Blaak, 1970; Breure and Soebagjo, 1991; Suwandi et al., 2012;

Van de Lande and Zadoks, 1999; VANDELANDE, 1993)

\section{Bud rot disease : Phytophthora palmivora (First Report,}

Overview, Molecular identification, causal agent, diseases type)

Number of References : 5

(De Franqueville, 2003; Duff, 1962; MARIAU et al., 1992; Navia et al., 2011; Torres et al., 2010)

absence of differential predation, a critical review of the

development of rat control).

Number of References : 3

(Jakel et al., 1999; Chong Leong Puan et al., 2011; Wood and Fee, 2003)

\section{The planthopper : Zophiuma butawengi, Agents}

(Parastethynium maxwelli and Ooencyrtus Ashmead,

Ooencyrtus isabellae, Noyes sp); Topics (Potential for

biological control, Description and biological parameters, Re-

description and biology)

Number of References : 3

(Catherine Wanjiru Gitau et al., 2011; Guerrieri et al., 2011;

Huber et al., 2011)

Red ring disease : Bursaphelenchus cocophilus (role of the

palm weevil (Rhynchophorus-Palmarum), control (trapping of

Rhynchophorus palmarum)

Number of References :2

(Chinchilla et al., 1990; Oehlschlager et al., 2002a)

variability)

Number of References : 1

(Dominguez-Guerrero et al., 2012)

Finschhafen disorder (FD) (role of Zophiuma lobulata feeding)

Number of References : 1

(C. W. Gitau et al., 2011)

Trunk Rot : Thielaviopsis paradoxa (Characterization)

Number of References : 1 


\section{Part 3}

\section{Biological Control in Indonesian Oil Palm Potentially enhanced by Landscape Context}

Fuad Nurdiansyah, Lisa H. Denmead, Yann Clough, Kerstin Wiegand, and Teja Tscharntke 


\begin{abstract}
Oil palm plantation expansion is occurring at a rapid pace. However, substantial yield losses from pest attacks are becoming major threats to the oil palm industry, while the potential role of conservation biological control, a sustainable and environmentally friendly solution for pest control, is still largely unknown. The type of vegetation surrounding oil palm plantations can be hypothesized to influence pest predation, and we tested this in Indonesia (Sumatra), the worldwide largest palm oil producer. We studied six different vegetation types adjacent to oil palm plantations: another oil palm plantation (control), weedy oil palm, weedy rubber, scrub, jungle rubber, and secondary forest. Each border type was replicated eight times. We quantified predation rates and predator occurrences using dummy caterpillars and mealworms $20 \mathrm{~m}$ inside of the adjacent vegetation as well as $20 \mathrm{~m}$ and $50 \mathrm{~m}$ inside the oil palm plantation. Ants and bush crickets were the most prominent predators in the plantations, whereas birds, bats, monkeys, beetles, and molluscs played a minor role. Mean percentage of ant and cricket predation rate in control border OUT 20 were $16.39 \%$ and $7.16 \%$ respectively, IN 20 were $16.03 \%$ and 6.1\%, and IN 50 were $14.47 \%$ and $7.48 \%$, while for other borders except control, mean percentages OUT $20 \mathrm{~m}$ were $28.90 \%$ and $12.26 \%$ respectively, IN $20 \mathrm{~m}$ were $26.61 \%$ and $12.40 \%$, and IN $50 \mathrm{~m}$ were $22.93 \%$ and $10.58 \%$. Predation rates were $~ 70 \%$ higher in non-oil palm habitat, indicating the need for improved vegetation diversification inside plantations. Overall predation rates in oil palm decreased slightly but significantly with distance to the border. Our results suggest that oil palm management maintaining non-oil palm vegetation in the adjacent areas and weedy plant strips inside the plantation may be most promising for effective conservation biological control in the future.
\end{abstract}

\title{
Keywords
}

Ant, pest management, predation, predatory crickets, conservation, biological control 


\section{Introduction}

Oil palm plantation expansion is occurring at a rapid pace (Foster et al., 2011), particularly due to it being the highest yielding vegetable oil crop per unit area (Murphy, 2009). However, substantial yield losses from pest attacks are becoming major threats to the oil palm industry (Constantin et al., 2013; Kamarudin and Wahid, 2010; Woruba et al., 2014). Pests can be potentially controlled through two main methods, chemical inputs (pesticides) or biocontrol (Wood, 2002). Compared to pesticide applications, biocontrol is known as a sustainable and ecofriendly solution to reduce pest numbers below economic level by using natural enemies (Hajek, 2004; Norris et al., 2003). However, research on factors influencing biocontrol agents in oil palm plantations, such as landscape context or local management, is lacking but urgently needed to understand the potential for biocontrol methods to stop yield losses from pest attacks.

Oil palms are attacked by a large number of insect pests (e.g. trunk borers and defoliators) and diseases (e.g. Ganoderma, Fusarium, and Phytomonas) (Corley and Tinker, 2008). Both of which occur often in oil palm plantations and have a high impact on oil palm production (Corley and Tinker, 2008; Foster et al., 2011; Wood, 2002). However, defoliating pests, in particular bagworms (Psychidae) and nettle caterpillars (Limacodidae), play one of the most important roles in reducing crop yield due to their high reproduction and mobility (Wood, 2002). For example, bagworms can cause up to 50\% yield loss at high infestation levels (Basri et al., 1995; Kamarudin and Wahid, 2010), while nettle caterpillars can cause 29\% and 31\% yield reduction after the first and second year of infestation respectively (Potineni and Saravanan, 2013). Significant pest attacks can be related to an imbalance between pests and their natural enemies (Igbinosa, 1992; Wood, 2002). In the past, pest resurgence after insecticide application was assumed to be a major cause of the imbalance (Wood, 1971). However, despite the decline 
in use of broad spectrum-long residual contact-insecticides (bslrcs), pest numbers have still continued to reach detrimental numbers in many locations (Kamarudin and Wahid, 2010; Wood, 2002). Investigation of methods for promoting biocontrol agents in plantations is therefore crucial for decreasing pest outbreaks and maintaining or increasing production levels (Corley and Tinker, 2008; Foster et al., 2011).

Fostering native biocontrol in oil palm plantations through local or landscape management may be an important approach to decreasing pest populations. Conversion to oil palm plantations results in highly simplified landscapes leading to huge biodiversity losses for a wide range of organisms, including biocontrol agents (Barnes et al., 2014; Dislich et al., In Revision; Fitzherbert et al., 2008). Of particular concern is a decline in predatory species (Denmead et al., In Review), which are the main cause of defoliator pest mortality in the field (Wood, 2002). For example, Aratrakorn et al (2006), and Koh (2008) found that insectivorous birds have difficulty adapting to oil palm plantations and therefore, have a reduced capacity for top-down control of crop pests (Aratrakorn et al., 2006; Koh, 2008a, 2008b). Ant community composition is also largely changed, with many forest species lost and decline in predatory species ((Rubiana et al., 2015, Denmead et al. in prep.). Dejean et al (1997) reported that when two predatory ants, Crematogaster gabonensis and Tetramorium aculeatum, occupied oil palm plantations in Cameroon, there were lower attack rates by a leaf-mining beetle (Coleoptera: Chrysomelidae). However, studies on the biocontrol of oil palm pests in the past have mostly focused on the introduction of exotic biocontrol agents to the field or assessments of potential agents (Bakeri et al., 2009; Kamarudin and Wahid, 2010; Zeddam et al., 2003), rather than evaluating factors influencing the native enemy population. There has been no comprehensive study that links pests to native biocontrol agents (Foster et al., 2011; Savilaakso et al., 2014). A 
potential method for increasing biodiversity, and in particular native biocontrol agents, in the plantations are the increase of landscape heterogeneity through such approaches as protecting riparian buffers (Gray and Lewis, 2014), leaving patches of natural forest and agroforestry within the landscape, and enhancing the understorey vegetation (Koh, 2008a; Koh et al., 2009). Thus, increasing landscape complexity and connectivity among habitats may provide a way to manipulate biological control in agroecosystems (Tscharntke et al., 2012, 2007).

Developing ecologically sound integrated pest management strategies in such a rapidly expanding agricultural system will be extremely important for the sustainability of the crop and the wider ecosystems in the long term. However, these concerns have only received little attention in the past. Here, we investigated if the surrounding landscape and the distance from border influence predator predation rates in oil palm plantations in Sumatra, Indonesia. We measured predation rates and predator occurrences using dummy caterpillars and mealworms in oil palm plantations bordered by important vegetation types such as another oil palm plantation (control), weedy oil palm, weedy rubber, scrub, jungle rubber, and secondary forest to determine if the border type can influence the potential for biocontrol in the plantations. We also surveyed a key predator group (ants) in different vegetation types to link predation rates with probable predators. Understanding how the landscape context and management can influence biocontrol agents in oil palm plantations is a crucial factor to allow farmers to promote biocontrol of crop pests. 


\section{Methods}

\subsection{Study area}

The study was conducted within two regions in the Batanghari and Sarolangun Regencies in Jambi Province, Sumatra, Indonesia. Both study regions were located in the lowland area of the province with potential vegetation of tropical lowland rainforest. However, there has been considerable land-use change in the province over the past 50 years as result of the expansion of agricultural land. In particular, more recently, the area cultivated as oil palm plantations increased from 150,000 ha to 550,000 ha in the period from 1996 to 2011 (Gatto et al. 2014), making oil palm one of the most dominant crops in the province.

Four important vegetation types in the study area include degraded lowland rainforest, jungle rubber (agroforestry system consisting of degraded forest with rubber trees between native vegetation), rubber plantations, and oil palm plantations. A major arthropod predator group across all these vegetation types is ants, which maintains dominance across all systems, with even slightly higher abundances and richness in oil palm plantations compared to other systems (Table 1, Appendix A) and predatory ants lowest in the oil palm plantations (Table 1) (Denmead et al., In Review). Pest attacks, especially nettle caterpillars, were reported only in few study areas, but farmer immediately spray pesticide to manage them before reaching outbreak level. The most common herbivores in the area were Geometridae caterpillars which can be found in every study areas, but their attack were not categorized as pest by farmers.

\subsection{Experimental design}

Sample and data collection were completed from October 2012 to June 2014 at the border of oil palm plantations that were surrounded by six different vegetation types: another oil palm plantation (control), weedy oil palm, weedy rubber, scrub, jungle rubber, and secondary forest 
(Figure 1). In each of the two study regions each border type was replicated four times (n=48 sites) (Figure A1). The minimum distance from a selected border to another was in average 500 metres. The age of the oil palm plantations was from five to 15-years-old.

At each of these 48 sites, we conducted our research at three locations: $20 \mathrm{~m}$ from border into the adjacent vegetation (OUT 20) and $20 \mathrm{~m}$ and $50 \mathrm{~m}$ into the focal oil palm plantation (IN 20 and IN 50) (Figure A2). Each location consisted of two stations. Inside the plantation, each pair of stations was separated by one oil palm ( $20 \mathrm{~m})$. Inside the bordering vegetation, due to the high variance in vegetation the stations were not centred on particular trees, rather, at each station we marked a five metre long transect perpendicular to the border beginning at $20 \mathrm{~m}$ from the border (OUT 20) (Figure 2). The distance between these stations (i.e. transects) was $20 \mathrm{~m}$.

\subsection{Measuring Predation Rates and Predator Occurrences}

We measured predation rates at the sites using dummy caterpillars (Howe et al., 2009) and predator occurrences using mealworms as exposed prey. The dummy caterpillars were modelled on the nettle caterpillar (Setothosea asigna), which is an important pest of oil palm. The caterpillars were made from a 50/50 mixture of brown and green plasticine and the size was similar to a ninth instar nettle caterpillar (3.6 cm long, $1.1 \mathrm{~cm}$ diameter). The mealworms (yellow mealworm, Tenebrio molitor) were collected from local bird traders, which sold them as bird food.

Ten dummy caterpillars and ten mealworms were exposed at each station (i.e., 60 of each prey type per border site, $n=2880$ ). Inside the plantation (IN 20 and IN 50), the caterpillars and mealworms were glued to four fronds on each selected oil palm with a minimum distance of 30 cm between each prey item (Figure A3). Inside the bordering vegetation (OUT 20), the dummy caterpillars and mealworms were glued to leaves between $1.5 \mathrm{~m}$ and $2 \mathrm{~m}$ high either side of the 
transect (Figure A3). The exposure time for the dummy caterpillars and exposed preys was four days and one day respectively. Preliminary experiments determined the chosen exposure time to be optimal for detecting differences in predation rates and predator occurrences. After exposure, dummy caterpillars were transported to the laboratory where they were examined for signs of predation using either a magnifying glass or a stereomicroscope. Mealworm damage was assessed directly in the field.

Camera traps were utilized inside the plantation nearby border types to observe predator type and activities on the dummy caterpillars and mealworms. Ten caterpillars or mealworms were glued on leaves about $30 \mathrm{~cm}$ in front of a camera lens. The camera took a picture every 2 minutes between 9 am until 5 pm two times a week for two months (Total 16 days of observation time). The use of camera traps allowed us to distinguish the types of damage produced by two major insect predator groups, ants and Orthoptera and therefore assign damage on mealworms to a particular predator (Figure 3). We observed the surface of dummy caterpillar can record multiple successive predators in the field and therefore the more marks left on the caterpillar can be representative as a proxy of higher predators abundances.

On the dummy caterpillars all marks caused by a predator's mandibles, teeth, beak, or ovipositor were recorded. Predation rate was expressed as percentage of dummy caterpillar surface area marked by predators (see Appendix A for detailed methods) and assigned to a predator group where possible. The quantification method should be understood with caution as previous studies found that the caterpillar only reveal visual cues, whilst lacking other caterpillar behaviour and production such as chemical signals, motion, frass and synomones from an attacked plant which might affect to lower predation rate on the caterpillar (Howe et al., 2009; Seifert et al., 2016; Tvardikova and Novotny, 2012). Even though the caterpillar may not reflect 
real predation rate in the field, it can record the relative number of predation incidents which can be comparable between different habitat (Howe et al., 2009). Missing dummy caterpillars were excluded from analysis. Damage recorded on the mealworms was classified into four categories of predator occurrence based on camera trap observations: 1) $0 \%$ damage $=$ no predator occurrence, 2) $20 \%$ damage = a single foraging ant, 3) 40 - 80\% predatory Orthoptera or Mantodea, 4) $100 \%$ = group of predatory ants.

\subsection{Statistical analysis}

We used linear mixed effect models (LMEs) (fitted by maximum likelihood (ML)) to investigate the effect of border type, location (OUT 20, IN 20, and IN 50), and their interaction on species-specific predation rates and predator occurrences (separately for the four predation damage categories), with site specified as a random effect. For both response variables we fitted four models with all combinations of explanatory variables (only border type, only location, both border type, and location with and without an interaction term) and ranked them by AIC score (Burnham et al., 2002). The model with the lowest AIC score was considered the best-fit model and used for analysis. If the best-fit model included only location, then the model was reanalysed excluding predation rates at the control border type. If the best-fit model included an interaction term, we created a new "interaction" variable and only included that in the final model for post-hoc analysis. When the final model contained a significant term we determined contrasts of interest post-hoc with the generalised linear hypothesis test (glht). To meet assumptions of normality, predation rate and predator occurrence were log transformed (+1 due to some zero abundances) before analysis. 
LMEs and post-hoc tests were carried out in R 2.13.0 environment (R Development Core Team, 2011) using the nlme (Pinheiro et al. 2015) and multcomp (Hothorn et al. 2008) packages respectively.

\section{Results}

\subsection{Predators of dummy caterpillar and exposed prey}

There were several predators which bit into the dummy caterpillars, including arthropods (Hymenoptera (ants), Orthoptera, and Coleoptera), birds, and mammals (bats and monkeys) (Figure 3). Ants and Orthoptera dominated the predation recorded with mean predation rates of $24.28 \%$ and $10.87 \%$ respectively. The other predators totalled less than $3 \%$ : bats $0.28 \%$, coleoptera $0.43 \%$, birds $0.04 \%$, monkeys $1.39 \%$, and molluscs $0.38 \%$ and were therefore left out of further analysis.

Similarly to the dummy caterpillars, ants and Orthoptera were also the main predators of the exposed prey (mealworms), with a total occurrence of 1660 and 728 out of 2880 prey, respectively. Pictures taken using camera traps and direct observation in the field during data collection also revealed that the majority of Orthoptera predating on dummy caterpillars and mealworms were the bush cricket, Nisitrus vittatus (Orthoptera: Gryllidae).

\subsection{Border type and location effects on predation rates}

At the control border, mean percentages of ant and Orthoptera predation rates at OUT 20 were $16.39 \%$ and $7.16 \%$ respectively, and $16.03 \%$ and $6.1 \%$ at IN 20 , and $14.47 \%$ and $7.48 \%$ at IN 50. Averaged across all other borders except control, mean percentages for ant and Orthoptera were $28.90 \%$ and $12.26 \%$, respectively, at OUT $20,26.61 \%$ and $12.40 \%$ at IN 20 , and $22.93 \%$ 
and 10.58\% IN 50. Comparison of AIC scores determined that the best-fit model for both ant and orthoptera predation rates included border type, location, and their interaction (Table B1).

The interaction term in the final model testing the influence of border types and locations on ant predation rate on dummy caterpillars was significant (Table B3). Post-hoc analysis of the influence of border type on ant predation rates inside the border vegetation (OUT 20) showed there were significantly higher ant predation rates in jungle rubber, weedy oil palm, and weedy rubber than in the control (oil palm plantation), and intermediate rates in the scrub (Figure 4a, Table B4). Within the oil palm (IN 20 and IN 50) both jungle rubber and weedy oil palm had significantly higher ant predation rates than the control (Figure 4a, Table B4). Weedy rubber and secondary forest also had significantly higher rates than the control at IN 20 and IN 50, respectively. For all but one border type (secondary forest) there was also a decline in predation rate with distance, from outside the plantation (OUT 20) to the furthest inside (IN 50) (Figure $4 a)$.

Orthoptera predation rates on dummy caterpillars were significantly influenced by border type, location, and their interaction (Table B4). Comparison of orthopteran predation rates within the border vegetation (OUT 20) showed a significantly higher predation rate in jungle rubber and weedy rubber compared with the control, and intermediate rates in secondary forest (Figure 4b, Table B4). Twenty metres within the oil palm plantation (IN 20), orthopteran predation rates were significantly higher in weedy rubber and secondary forest than in the control. However, 50 $\mathrm{m}$ within the plantation there was no significant difference in the predation rate between border types, indicating a decline in the effect of border type with distance to the border. 


\subsection{Border type and location effects on predator occurrences}

For predator occurrences, the best-fit model for all four predation damage categories (no damage, solitary ant, Orthoptera, and group of ants) included only location. Thus, the control values were excluded from the data and it was re-analysed, with the best-fit model still only including location (Table B2).

Location, the only variable in the final models testing influences on predator occurrences, had a significant effect on all four categories of predator occurrence on mealworms (Table B5). More specifically, for all predation damage categories except groups of ants (100\% damage), there was lower predator occurrence outside the border (OUT 20) than $20 \mathrm{~m}$ inside (IN 20) (Figure 5, Table B6). Solitary ants had similar occurrences $50 \mathrm{~m}$ inside (IN 50) as outside the plantation, but the orthopteran occurrence at $50 \mathrm{~m}$ inside was similar to $20 \mathrm{~m}$ inside (IN 20). The opposite was observed for group of ants, there were higher occurrences outside the plantation than inside (both IN 20 and IN 50) (Figure 5, Table B6).

\section{Discussion}

We found that the vegetation surrounding oil palm plantations and the distance from the border of the plantation affected both predation rates and predator occurrences. Predatory ants and Orthoptera were the dominant predators for the prey items tested and other animal groups only played minor role. Overall, predation rates were higher in plantations bordered by vegetation types other than another oil palm plantation. The distance from the plantation border also played a role in determining both predation rates and predator occurrences, with predation rates almost always lowest further into the plantation. 
The most dominant predators were ants and Orthoptera, whereas very low predation rates were recorded for the other predators recorded, i.e., bats, Coleopterans, birds, monkeys, and molluscs. Until now there have been no direct tests of potential predator groups on predation rates of defoliating insects in oil palm plantations except for one study by Basri et al. (1995) which focuses on the predatory beetle, Callimerus arcufer (Coleoptera: Cleridae), as potential predator of the bagworm, Metisa plana Walker (Lepidoptera: Psychidae). Other studies have shown the potential for birds to be important biocontrol agents in oil palm (Koh 2008a), and that the abundance of insectivorous birds can increase in plantations when the non-crop vegetation is enhanced (Nájera and Simonetti, 2010). However, none of these studies directly tested predation of oil palm pests. Although birds are very important for controlling herbivorous pests in many crops, their contribution to predation was very low in oil palm plantations. Surprisingly, $N$. vittatus was the most common Orthoptera predating on our prey, although $N$. vittatus is often identified as a pest of many trees and crops (e.g. Acacia mangium seedlings (Hamid, 1987)). Furthermore, species of Orthoptera from the family Tettigoniidae are one of the most important pests of oil palm in certain areas (e.g. Papua New Guinea (Howard et al., 2001)). Due to their significant contribution to predation however on both dummy caterpillars and mealworms, as well as their high occurrences in oil palm plantations, $N$. vittatus appeared to have the potential to act as insect biocontrol agent in oil palm, especially for caterpillar pests.

The majority of previous studies on the transformation of forest to oil palm plantation and its management intensification have reported extensive losses in biodiversity, in particular of higher tropic levels (Barnes et al., 2014). For example, Chung et al. (2000) found that forest conversion to oil palm reduces predatory beetles (Chung et al., 2000). Our results show that ants, although following the same pattern of predatory species loss, still remain one of the most 
dominant predators. This may be little surprising, as ants are still the dominant insect group in the plantation (Fayle et al., 2010; Pfeiffer et al., 2008), while ant community composition can influence oil palm herbivory rates (Dejean et al., 1997). The higher ant predation rate on the caterpillars indicates higher predatory ant activity (Human and Gordon, 1999; Klimes et al., 2011; Peters et al., 2009). We found some of the most dominant ant species in the plantations, such as Anoplolepis gracilipes, the yellow crazy ant (Fayle et al., 2013; Pfeiffer et al., 2008), which predated on the dummy caterpillars and the exposed prey. Although they are known as exotic tramp ants, which might displace other species, A. gracilipes, could be important for biocontrol in oil palm and in fact has been used to control herbivore populations in cocoa and coconut plantations (Way and Khoo, 1992).

Oil palm plantations surrounded by non-oil palm vegetation enhanced insect predation, possibly due to additional resources (Foster et al., 2011; Lucey and Hill, 2012; Mitchell et al., 2013). Landscape context is known to influence functional biodiversity in agricultural systems, although most studies have been conducted in temperate systems (Poveda et al., 2012; Tscharntke et al., 2007). In oil palm, so far only four studies investigated how to promote biocontrol in these plantations (Basri et al., 1995; Gitau et al., 2011; Kamarudin and Wahid, 2010; Koh, 2008b). In addition, Koh (2008b) found that increasing epiphyte and leguminous crop cover in the oil palm plantation can enhance insectivorous bird populations and Kamarudin \& Wahid (2010) observed that planting Cassia cobanensis within the vicinity of oil palm plantations can promote parasitoids of bagworms, a major oil palm pest (Kamarudin and Wahid, 2010). None of these studies however, investigated the effect of surrounding habitats on predation rates in the oil palm plantation. Nevertheless, retaining natural habitat, surrounding the plantation as a source for beneficial organisms, has been widely advocated by many authors 
(Foster et al., 2011; Koh et al., 2009). Our results suggest that different land uses such as jungle rubber, weedy oil palm, and weedy rubber can support predatory arthropods to deliver strong top-down effects on crop pests inside the plantation. Due to increases in predation pressure, maintaining natural habitat surroundings agricultural landscapes can support specifically beneficial species. Maintaining diverse habitats inside and surrounding oil palm plantations supports the movement of predatory insects and the potential for predators to control crop pests bridging biodiversity conservation and function (Lucey et al., 2014; Senior et al., 2013; Tscharntke et al., 2007). We therefore recommend improving predation rates by keeping alternative vegetation types such as jungle rubber, weedy oil palm, weedy rubber, and secondary forest near oil palm plantations. In particular, secondary forest and jungle rubber are also beneficial for many other species groups compared with plantations (Barnes et al., 2014; Prabowo et al., 2016) and should be retained surrounding the plantation as the best possible option. However, secondary forest as well as jungle rubber is becoming increasingly rare in the area as plantations spread and therefore development of the others recommended border types should also be encouraged to promote predatory arthropods. Reduced use of herbicides in oil palm and rubber plantations rapidly leads to increased weedy-flower vegetation growth which can not only promote predation rates as studied here but also otherother natural enemies, such as parasitoids (citation)..

The majority of the effects of border type tended to decline along the distance gradients, with (aside from a few exception) the lowest predation rates and predator occurrences the furthest into the plantation. Particular predator occurrence, especially group of ant, show the monoculture plantation adversely effect on them. Their occurrences in the plantation were relatively very low compare to inside the border habitat, might be due to lack of suitable 
vegetation for nesting and rich supplementary food in the plantation (Fayle et al., 2013, 2010;

Pfeiffer et al., 2008). An interesting exception occurred in the plantation nearby secondary forest borders where the predation rates were still similarly enhanced even at the furthest distance measured, $50 \mathrm{~m}$ inside the plantation. The general decline in insect predation rates towards the centre of the plantation needs further assessment, however, in order to quantify overall biological control effectiveness across the whole plantation area. Our results suggest that both ants and Orthoptera are major insect predators in oil palm plantation and might complement each other in pest suppression.

\section{Conclusions}

The present study suggests that ant and Orthoptera are the main predators of defoliating pests in oil palm plantations and their predation pressure are influenced by border types and edge effects. The higher attack pressure in plantations surrounded by jungle rubber, weedy oil palm, weedy rubber, and secondary forest suggests that diverse vegetation surrounding oil palm plantations could be useful for conserving predators and controlling oil palm pests, especially caterpillars. However, the border effect quickly declines with distance from the border so that management inside the plantation is necessary, for example through restoring or maintaining weedy understory or flowering plant strips. Better understanding of the ecological management of oil palm plantations including biological pest control needs more experimental studies testing the optimum plantation size and shape and the type and size of adjacent vegetation as well as the kind of ecological improvements inside the plantations with weedy strips. 


\section{Acknowledgments}

We thank David Warisman, Deslian Permana, Febrina Herawani, Rico Fardiansa, Derly Hartika, and Tutty for all their help in the lab and the field. We thank the village leaders and local smallholders for granting us the use of their properties. This study was financed by the Deutsche Forschungsgemeinschaft (DFG) in the framework of the collaborative German - Indonesian research project Collaborative Research Centre 990 EFForTS: Ecological and Socioeconomic Functions of Tropical Lowland Rainforest Transformation Systems (Sumatra, Indonesia). Fuad Nurdiansyah was supported by the German Academic Exchange Service (DAAD).

\section{References}

Aratrakorn, S., Thunhikorn, S., Donald, P.F., 2006. Changes in bird communities following conversion of lowland forest to oil palm and rubber plantations in southern Thailand. Bird Conserv. Int. 16, 71. doi:10.1017/S0959270906000062

Bakeri, S.A., Ali, S.R.A., Tajuddin, N.S., Kamaruzzaman, N.E., 2009. Efficacy of entomopathogenic fungi, Paecilomyces spp., in controlling the oil palm bagworm, Pteroma pendula (Joannis). J. Oil Palm Res. 21, 693-699.

Barnes, A.D., Jochum, M., Mumme, S., Haneda, N.F., Farajallah, A., Widarto, T.H., Brose, U., 2014. Consequences of tropical land use for multitrophic biodiversity and ecosystem functioning. Nat. Commun. 5, 5351. doi:10.1038/ncomms6351

Basri, M.W., Norman, K., Hamdan, A.B., 1995. Natural enemies of the bagworm, Metisa plana Walker (Lepidoptera: Psychidae) and their impact on host population regulation. Crop Prot. 14, 637-645. doi:10.1016/0261-2194(95)00053-4

Burnham, K.P., Anderson, D.R., Burnham, K.P., 2002. Model selection and multimodel inference: a practical information-theoretic approach, 2nd ed. ed. Springer, New York.

Chung, A.Y.C., Eggleton, P., Speight, M.R., Hammond, P.M., Chey, V.K., 2000. The diversity of beetle assemblages in different habitat types in Sabah, Malaysia. Bull. Entomol. Res. 90, 475-496.

Constantin, M., Ntsefong, G.N., Frank, N.E.G., Nchu, W.A., Parh, I.A., Luc, D., 2013. Spatiotemporal distribution of Coelaenomenodera minuta Uhmann (Coleoptera:

Chrysomelidae), a serious insect pest of oil palm (Elaeis guineensis Jacq.) in the southwest region of Cameroon. Albanian J Agric Sci 12, 479-483.

Corley, R.H.V., Tinker, P.B.H., 2008. The Oil Palm. John Wiley \& Sons.

Dejean, A., DjietoLordon, C., Durand, J.L., 1997. Ant mosaic in oil palm plantations of the southwest province of Cameroon: Impact on leaf miner beetle (Coleoptera:

Chrysomelidae). J. Econ. Entomol. 90, 1092-1096. 
Denmead, L.H., Klarner, B., Grass, I., Clough, Y., Krashevska, V., Liza, W., Rizali, A., Scheu, S., Widyastuti, R., Tscharntke, T., In Review. Ants affect belowground invertebrate communities and associated ecosystem processes across tropical land-use systems. Ecosphere.

Dislich, C., C. Keyel, A., Salecker, J., Kisel, Y., M. Meyer, K., D. Corre, M., Faust, H., Hess, B., Knohl, A., Kreft, H., Meijide, A., Nurdiansyah, F., Otten, F., Pe’er, G., Steinebach, S., Tarigan, S., Tscharntke, T., Tölle, M., Wiegand, K., In Revision. Ecosystem functions of oil palm plantations: a review. Biol. Rev.

Fayle, T.M., Turner, E.C., Foster, W.A., 2013. Ant mosaics occur in SE Asian oil palm plantation but not rain forest and are influenced by the presence of nest-sites and nonnative species. Ecography 36, 1051-1057. doi:10.1111/j.1600-0587.2012.00192.x

Fayle, T.M., Turner, E.C., Snaddon, J.L., Chey, V.K., Chung, A.Y.C., Eggleton, P., Foster, W.A., 2010. Oil palm expansion into rain forest greatly reduces ant biodiversity in canopy, epiphytes and leaf-litter. Basic Appl. Ecol. 11, 337-345. doi:10.1016/j.baae.2009.12.009

Fitzherbert, E., Struebig, M., Morel, A., Danielsen, F., Bruhl, C., Donald, P., Phalan, B., 2008. How will oil palm expansion affect biodiversity? Trends Ecol. Evol. 23, 538-545. doi:10.1016/j.tree.2008.06.012

Foster, W.A., Snaddon, J.L., Turner, E.C., Fayle, T.M., Cockerill, T.D., Ellwood, M.D.F., Broad, G.R., Chung, A.Y.C., Eggleton, P., Khen, C.V., Yusah, K.M., 2011. Establishing the evidence base for maintaining biodiversity and ecosystem function in the oil palm landscapes of South East Asia. Philos. Trans. R. Soc. B Biol. Sci. 366, 3277-3291. doi:10.1098/rstb.2011.0041

Gitau, C.W., Gurr, G.M., Dewhurst, C.F., Nicol, H., Fletcher, M., 2011. Potential for biological control of Zophiuma butawengi (Heller) (Hemiptera: Lophopidae) in coconut and oil palms using the hymenopterans Ooencyrtus sp (Encyrtidae) and Parastethynium maxwelli (Girault) (Mymaridae). Biol. Control 59, 187-191. doi:10.1016/j.biocontrol.2011.07.008

Gray, C.L., Lewis, O.T., 2014. Do riparian forest fragments provide ecosystem services or disservices in surrounding oil palm plantations? Basic Appl. Ecol. 15, 693-700. doi:10.1016/j.baae.2014.09.009

Hajek, A.E., 2004. Natural Enemies: An Introduction to Biological Control. Cambridge University Press.

Hamid, A.A., 1987. Insect pests of Acacia mangium Willd. in Sarawak. For. Res. Rep. - For. Entomol. Unit For. Dep. Sarawak 10 pp.

Hothorn, T., Bretz, F., Westfall, P., 2008. Simultaneous inference in general parametric models. Biom. J. 50, 346-363.

Howard, F.W., Giblin-Davis, R., Moore, D., Abad, R., 2001. Insects on Palms. CABI.

Howe, A., Lövei, G.L., Nachman, G., 2009. Dummy caterpillars as a simple method to assess predation rates on invertebrates in a tropical agroecosystem. Entomol. Exp. Appl. 131, 325-329. doi:10.1111/j.1570-7458.2009.00860.x

Human, K.G., Gordon, D.M., 1999. Behavioral interactions of the invasive Argentine ant with native ant species. Insectes Sociaux 46, 159-163.

Igbinosa, I.B., 1992. Field and laboratory techniques for assessing infestations of the nettle caterpillar, Latoia viridissima Holland (Lepidoptera: Limacodidae). Insect Sci. Its Appl. 13, 389-398. 
Kamarudin, N., Wahid, M.B., 2010. Interactions of the bagworm, Pteroma pendula (Lepidoptera: Psychidae), and its natural enemies in an oil palm plantation in Perak. J. Oil Palm Res. 22, 758-764.

Klimes, P., Janda, M., Ibalim, S., Kua, J., Novotny, V., 2011. Experimental suppression of ants foraging on rainforest vegetation in New Guinea: testing methods for a whole-forest manipulation of insect communities. Ecol. Entomol. 36, 94-103. doi:10.1111/j.13652311.2010.01250.x

Koh, L.P., 2008a. Birds defend oil palms from herbivorous insects. Ecol. Appl. 18, 821-825. doi:10.1890/07-1650.1

Koh, L.P., 2008b. Can oil palm plantations be made more hospitable for forest butterflies and birds? J. Appl. Ecol. 45, 1002-1009. doi:10.1111/j.1365-2664.2008.01491.x

Koh, L.P., Levang, P., Ghazoul, J., 2009. Designer landscapes for sustainable biofuels. Trends Ecol. Evol. 24, 431-438. doi:10.1016/j.tree.2009.03.012

Lucey, J.M., Hill, J.K., 2012. Spillover of insects from rain forest into adjacent oil palm plantations. Biotropica 44, 368-377. doi:10.1111/j.1744-7429.2011.00824.x

Lucey, J.M., Tawatao, N., Senior, M.J.M., Chey, V.K., Benedick, S., Hamer, K.C., Woodcock, P., Newton, R.J., Bottrell, S.H., Hill, J.K., 2014. Tropical forest fragments contribute to species richness in adjacent oil palm plantations. Biol. Conserv. 169, 268-276. doi:10.1016/j.biocon.2013.11.014

Mitchell, M.G.E., Bennett, E.M., Gonzalez, A., 2013. Linking landscape connectivity and ecosystem service provision: current knowledge and research gaps. Ecosystems 16, 894908. doi:10.1007/s10021-013-9647-2

Murphy, D.J., 2009. Oil palm: future prospects for yield and quality improvements. Lipid Technol. 21, 257-260. doi:10.1002/lite.200900067

Nájera, A., Simonetti, J.A., 2010. Can oil palm plantations become bird friendly? Agrofor. Syst. 80, 203-209. doi:10.1007/s10457-010-9278-y

Norris, R.F., Caswell-Chen, E.P., Kogan, M., 2003. Concepts in Integrated Pest Management. Prentice Hall.

Peters, M., Fischer, G., Schaab, G., Kraemer, M., 2009. Species compensation maintains abundance and raid rates of African swarm-raiding army ants in rainforest fragments. Biol. Conserv. 142, 668-675. doi:10.1016/j.biocon.2008.11.021

Pfeiffer, M., Cheng Tuck, H., Chong Lay, T., 2008. Exploring arboreal ant community composition and co-occurrence patterns in plantations of oil palm Elaeis guineensis in Borneo and Peninsular Malaysia. Ecography 31, 21-32. doi:10.1111/j.2007.09067590.05172.X

Pinheiro, J., Bates, D., DebRoy, S., Sarkar, D., R Core Team, 2015. nlme: Linear and nonlinear mixed effects models, $\mathrm{R}$ package version 3.1-120. R package version 3.1-120.

Potineni, K., Saravanan, L., 2013. Natural enemies of oil palm defoliators and their impact on pest population. Pest Manag. Hortic. Ecosyst. 19, 179-184.

Poveda, K., Martínez, E., Kersch-Becker, M.F., Bonilla, M.A., Tscharntke, T., 2012. Landscape simplification and altitude affect biodiversity, herbivory and Andean potato yield: Landscape affects potato pests and yield. J. Appl. Ecol. 49, 513-522. doi:10.1111/j.13652664.2012.02120.x

Prabowo, W.E., Darras, K., Clough, Y., Toledo-Hernandez, M., Arlettaz, R., Mulyani, Y.A., Tscharntke, T., 2016. Bird Responses to Lowland Rainforest Conversion in Sumatran 
Smallholder Landscapes, Indonesia. PLOS ONE 11, e0154876.

doi:10.1371/journal.pone.0154876

R Core Team, 2015. R: A Language and Environment for Statistical Computing. R Foundation for Statistical Computing, Vienna, Austria.

Rubiana, R., Rizali, A., Denmead, L.H., Alamsari, W., Hidayat, P., Pudjianto, D.H., Clough, Y., Tscharntke, T., Buchori, D., 2015. Agricultural land use alters species composition but not species richness of ant communities. Asian Myrmecol. 7, 73-85.

Savilaakso, S., Garcia, C., Garcia-Ulloa, J., Ghazoul, J., Groom, M., Guariguata, M.R., Laumonier, Y., Nasi, R., Petrokofsky, G., Snaddon, J., Zrust, M., 2014. Systematic review of effects on biodiversity from oil palm production. Environ. Evid. 3, 4. doi:10.1186/2047-2382-3-4

Seifert, C.L., Schulze, C.H., Dreschke, T.C.T., Frötscher, H., Fiedler, K., 2016. Day vs. night predation on artificial caterpillars in primary rainforest habitats - an experimental approach. Entomol. Exp. Appl. 158, 54-59. doi:10.1111/eea.12379

Senior, M.J.M., Hamer, K.C., Bottrell, S., Edwards, D.P., Fayle, T.M., Lucey, J.M., Mayhew, P.J., Newton, R., Peh, K.S.-H., Sheldon, F.H., Stewart, C., Styring, A.R., Thom, M.D.F., Woodcock, P., Hill, J.K., 2013. Trait-dependent declines of species following conversion of rain forest to oil palm plantations. Biodivers. Conserv. 22, 253-268. doi:10.1007/s10531-012-0419-7

Tscharntke, T., Bommarco, R., Clough, Y., Crist, T.O., Kleijn, D., Rand, T.A., Tylianakis, J.M., van Nouhuys, S., Vidal, S., 2007. Conservation biological control and enemy diversity on a landscape scale. Biol. Control 43, 294-309. doi:10.1016/j.biocontrol.2007.08.006

Tscharntke, T., Tylianakis, J.M., Rand, T.A., Didham, R.K., Fahrig, L., Batáry, P., Bengtsson, J., Clough, Y., Crist, T.O., Dormann, C.F., Ewers, R.M., Fründ, J., Holt, R.D., Holzschuh, A., Klein, A.M., Kleijn, D., Kremen, C., Landis, D.A., Laurance, W., Lindenmayer, D., Scherber, C., Sodhi, N., Steffan-Dewenter, I., Thies, C., van der Putten, W.H., Westphal, C., 2012. Landscape moderation of biodiversity patterns and processes - eight hypotheses. Biol. Rev. 87, 661-685. doi:10.1111/j.1469-185X.2011.00216.x

Tvardikova, K., Novotny, V., 2012. Predation on exposed and leaf-rolling artificial caterpillars in tropical forests of Papua New Guinea. J. Trop. Ecol. 28, 331-341. doi:10.1017/S0266467412000235

Way, M.J., Khoo, K.C., 1992. Role of ants in pest management. Annu. Rev. Entomol. 37, 479503.

Wielgoss, A., Tscharntke, T., Buchori, D., Fiala, B., Clough, Y., 2010. Temperature and a dominant dolichoderine ant species affect ant diversity in Indonesian cacao plantations. Agric. Ecosyst. Environ. 135, 253-259. doi:10.1016/j.agee.2009.10.003

Wood, B.J., 2002. Pest control in Malaysia's perennial crops: a half century perspective tracking the pathway to integrated pest management. Integr. Pest Manag. Rev. 7, 173-190.

Wood, B.J., 1971. Development of integrated control programs for pests of tropical perennial crops in Malaysia, in: Biological Control. Springer, pp. 422-457.

Woruba, D.N., Priest, M.J., Dewhurst, C.F., Gitau, C.W., Fletcher, M.J., Nicol, H.I., Gurr, G.M., 2014. Entomopathogenic fungi of the oil palm pest, Zophiuma butawengi (Fulgoromorpha: Lophopidae), and potential for use as biological control agents: Entomopathogenic fungi of Z. butawengi. Austral Entomol. 53, 268-274. doi:10.1111/aen.12073 
Zeddam, J.L., Cruzado, J.A., Rodriguez, J.L., Ravallec, M., 2003. A new nucleopolyhedrovirus from the oil-palm leaf-eater Euprosterna elaeasa (Lepidoptera : Limacodidae):

preliminary characterization and field assessment in Peruvian plantation. Agric. Ecosyst. Environ. 96, 69-75. doi:10.1016/S0167-8809(03)00034-3 


\section{Figure captions}

Figure 1. The types of vegetation bordering the oil palm plantations included in this study.

A) Control (oil palm plantation), B) weedy oil palm plantation, C) weedy rubber plantation, D) scrub, E) jungle rubber, and F) secondary forest.

Figure 2. The experimental design at each border included in the study. All research was conducted at three paired locations at each border: (A) two 5 m transects within the bordering vegetation at $20 \mathrm{~m}$ from the border (OUT 20) and two oil palms within the oil palm plantation at (B) $20 \mathrm{~m}$ from the border (IN 20) and (C) $50 \mathrm{~m}$ from the border (IN 50).

Figure 3. Observations of predation by the main predators. A) Camera trap photos of the main predators. Ants and crickets attacking $(1,2)$ a dummy caterpillar and $(3,4)$ a mealworm. B). Marks of predator bites on dummy caterpillars made by some predator groups.

Figure 4. The effects of border type on (A) ant and (B) Orthoptera predation rates of the dummy caterpillars at three different locations. Means with different letters within location are significantly different $(\mathrm{p} \leq 0.05)$.

Figure 5. The effect of locations on predator occurrences on the exposed prey. Mean with different letters are significantly different among locations $(p \leq 0.05)$. 

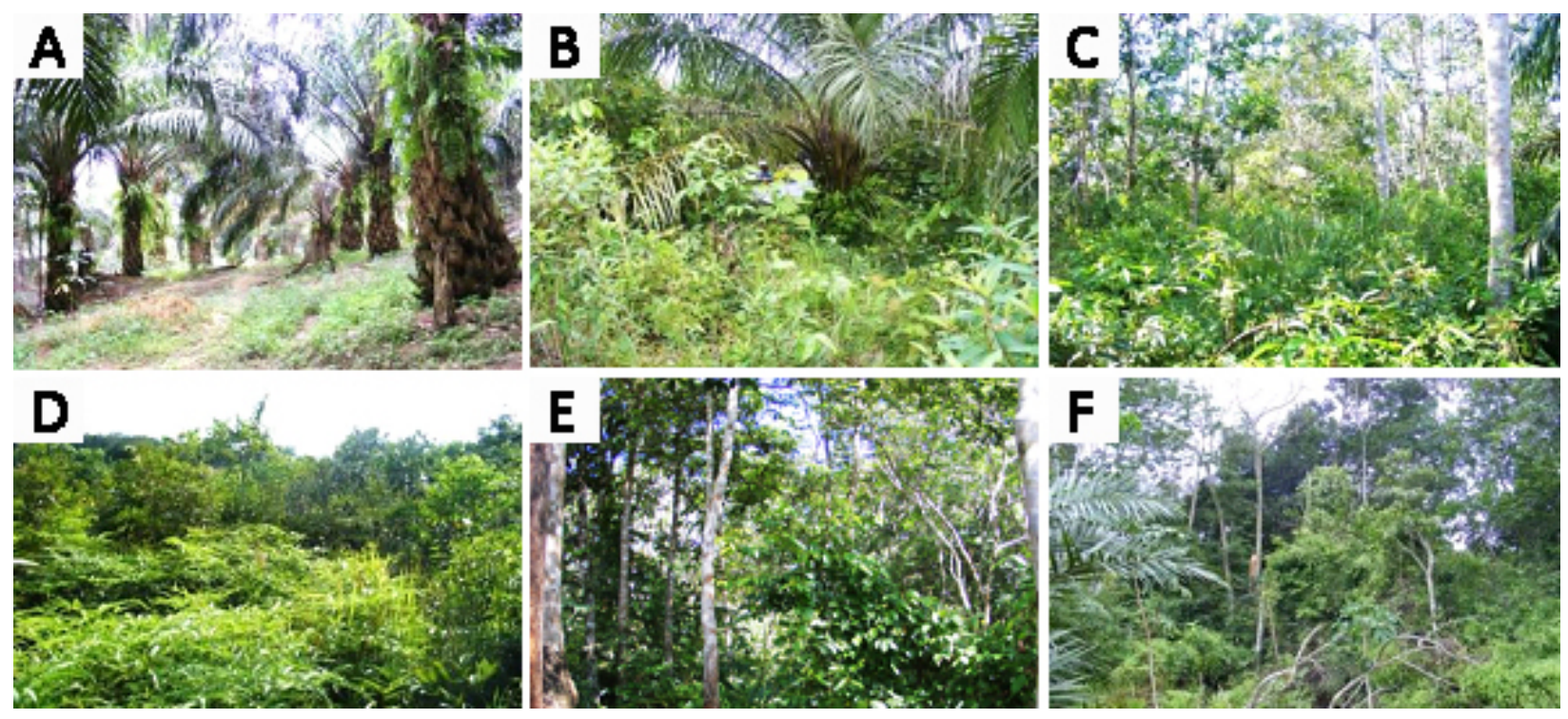

Figure 1. 


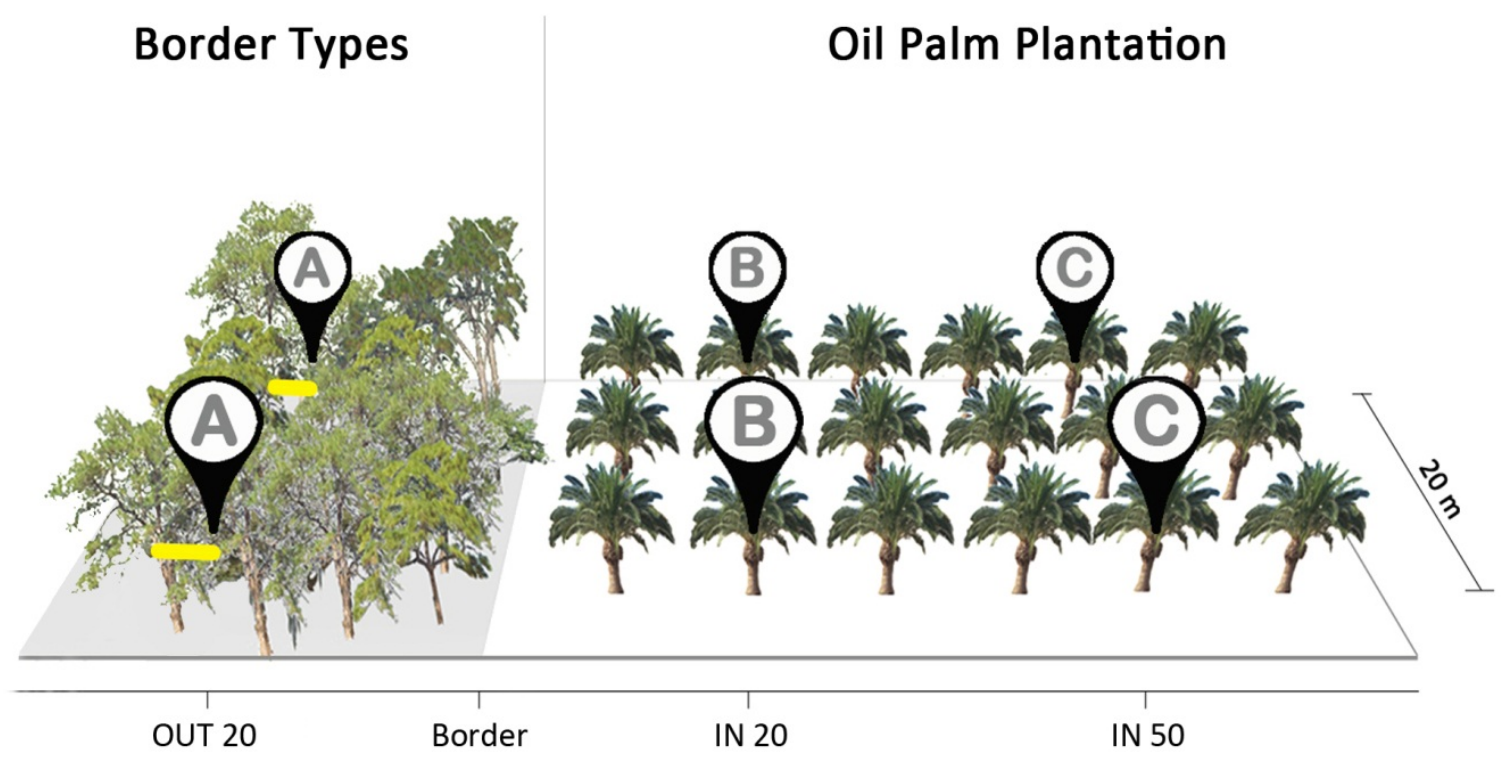

Figure 2. 


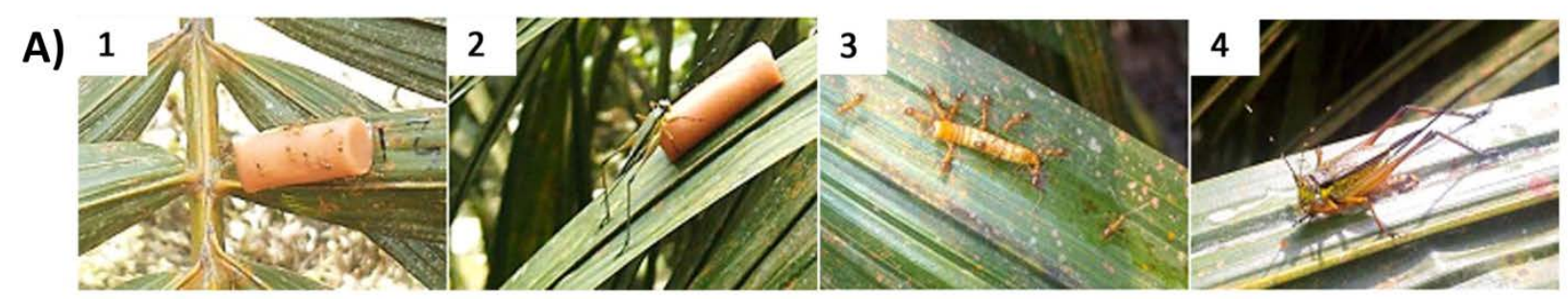

B)

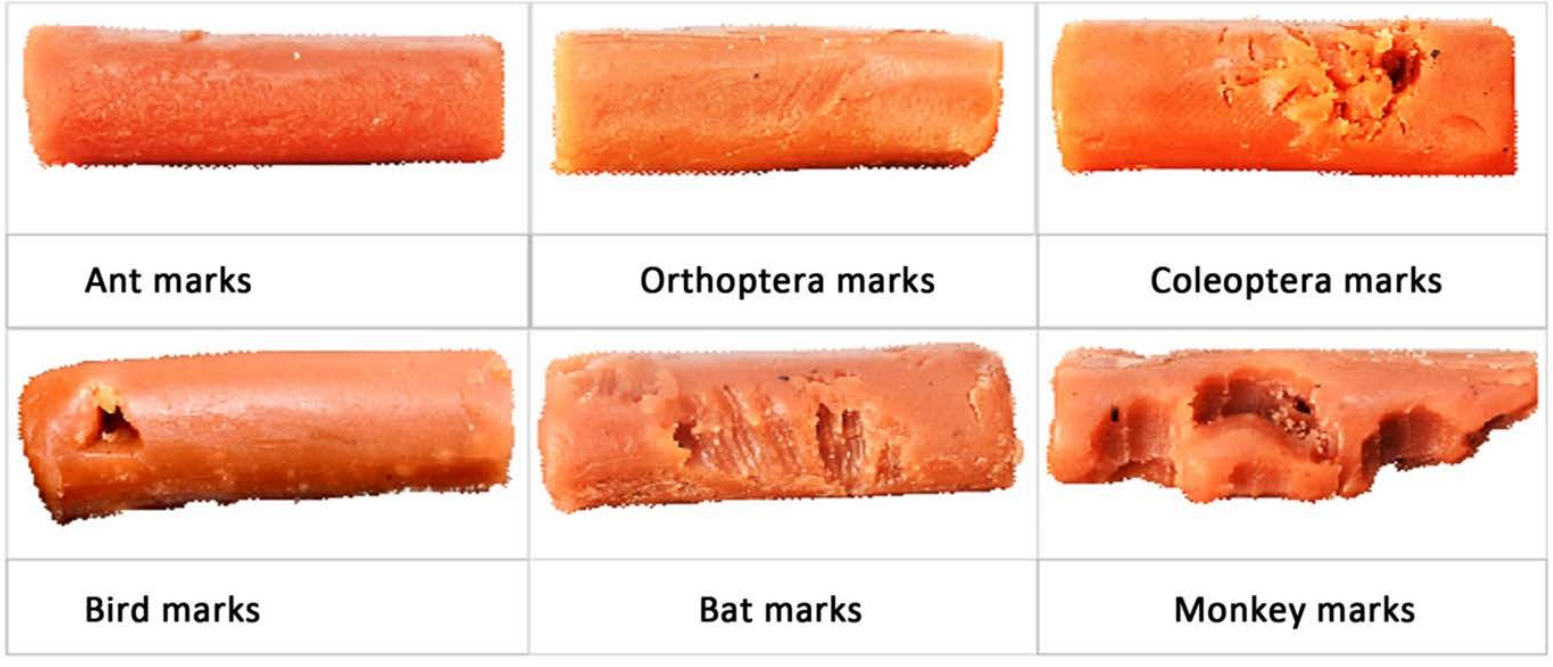

Figure 3. 


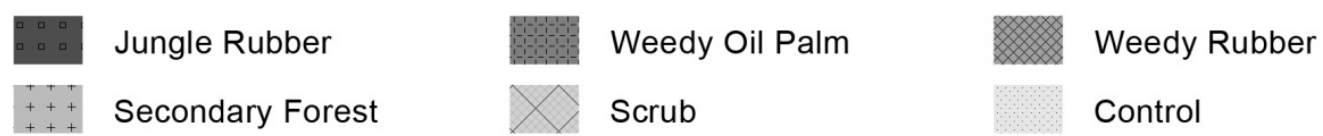

A)

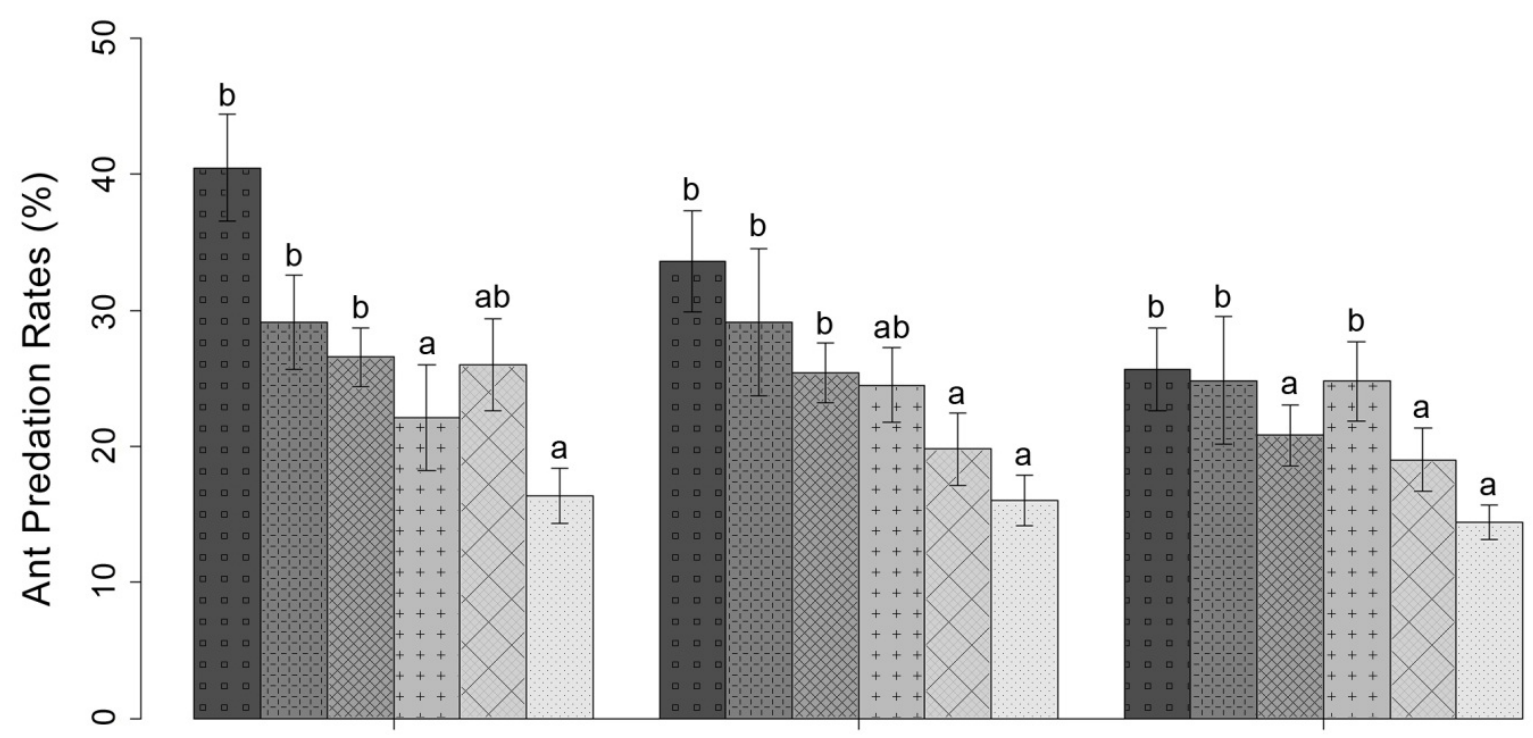

B)

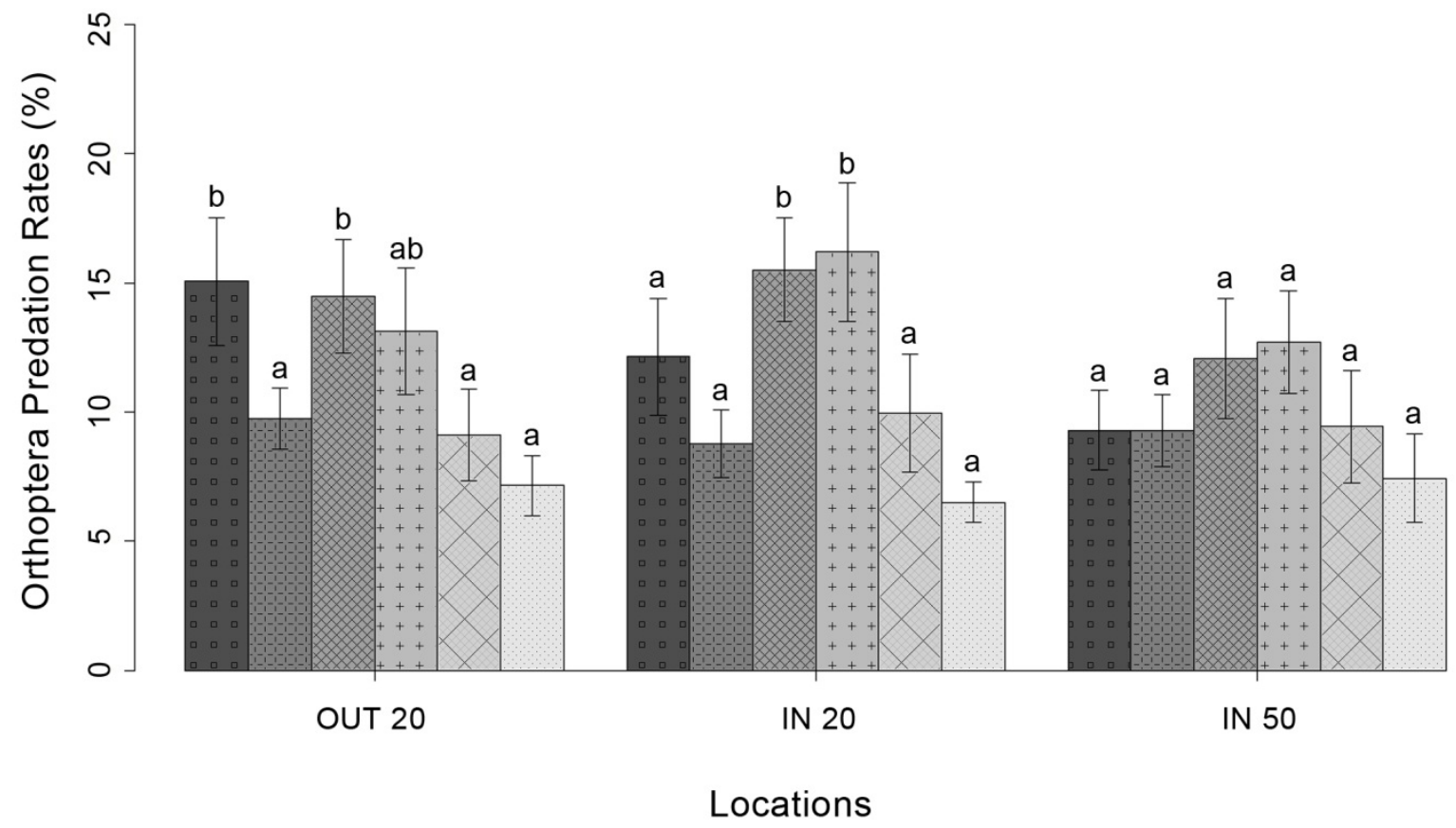

Figure 4. 


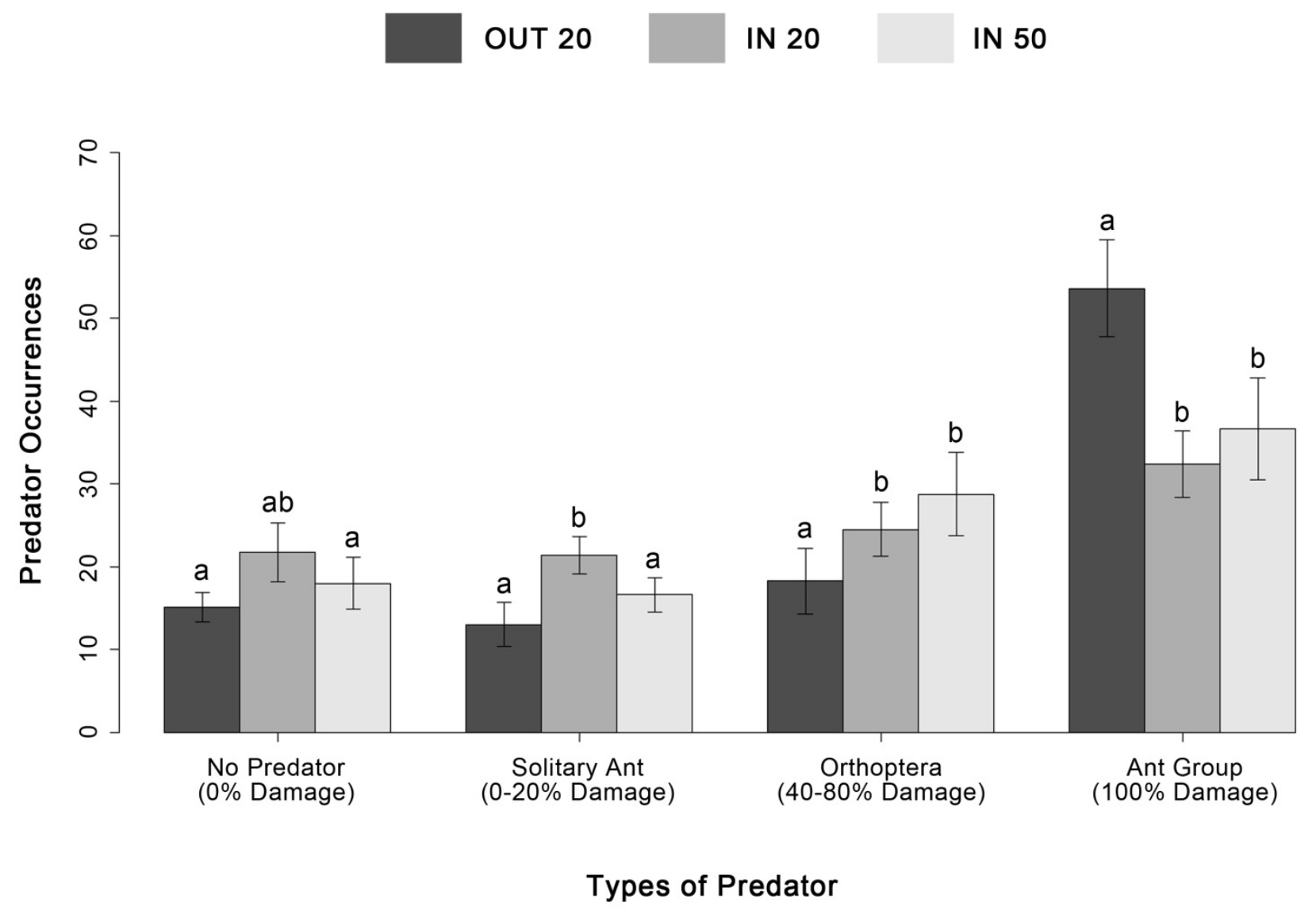

Figure 5. 
Table 1. Ant community composition measures (mean \pm SE, $n=8$ ) for each land-use system. Ant community responses to vegetation type were also tested using Linear Mixed-Effects models (LMEs) with region specified as a random effect (Table A1). Means (within rows) with different letters are significantly different (Tukey’s HSD, $\mathrm{p} \leq 0.05$ ) (Table A2). Community Weighted Mean $(C W M)$ preference ratio = community weighted mean (abundance-weighted mean trait values for a community) for the protein/carbohydrate preference ratio, a higher ratio indicates increased predator abundance (Appendix A).

\begin{tabular}{llllc}
\hline & Forest & Jungle rubber & Rubber & Oil palm \\
\hline Ant species richness & $9.25 \pm 0.62 \mathrm{ab}$ & $8.75 \pm 0.92 \mathrm{a}$ & $12.50 \pm 0.68 \mathrm{bc}$ & $14.50 \pm 1.35 \mathrm{c}$ \\
Ant abundance & $15.72 \pm 3.93 \mathrm{a}$ & $14.57 \pm 4.15 \mathrm{a}$ & $17.15 \pm 2.85 \mathrm{a}$ & $26.13 \pm 5.19 \mathrm{~b}$ \\
CWM preference ratio & $0.77 \pm 0.02 \mathrm{a}$ & $0.72 \pm 0.03 \mathrm{ab}$ & $0.75 \pm 0.02 \mathrm{a}$ & $0.65 \pm 0.01 \mathrm{~b}$ \\
\hline
\end{tabular}




\section{Supplementary Material}

\section{Appendix A. Supplementary methods.}

\section{Ant sampling in different vegetation types}

Ant sampling was conducted across four different vegetation types: degraded lowland rainforest, jungle rubber, rubber plantation and oil palm plantation. In the two study regions, each vegetation type was replicated four times $(n=32)$. At each of the 32 study sites, a $50 \mathrm{~m}$ x $50 \mathrm{~m}$ sampling plot was defined, which included five randomly assigned $5 \mathrm{~m}$ x $5 \mathrm{~m}$ subplots. All sites were on little or no slope and there was a minimum distance of 120 m between each site (mean distance between sites was $14.9 \mathrm{~km}$ ). The rainforest sites were within Bukit Duabelas National Park and Harapan Rainforest and, although protected, have been selectively logged in the past. The rubber and oil palm plantations, were intensively managed monoculture systems, with the oil palm plantations resembling the "control” border vegetation type described above.

We used plastic observation plates with two baits of $2 \mathrm{~cm}^{3}$ of tuna in oil and two sponges saturated with 70\% sucrose solution attached to sample ant species (Wielgoss et al., 2010). One plate was tied at breast height on each of two randomly selected trees in all five subplots at each site. If there were not two trees in a subplot (often the case in oil palm plantations), the closest trees to the subplot were chosen. At 15, 30, 45, and 60 minutes after placing the plates on the trees, the abundance of each ant species present on the plate (separately for ants feeding on sugar or tuna) was recorded. Specimens were collected from each ant species present where possible without disrupting recruitment. Surveys were conducted at each site four times during the study period (first: October 2012, second: February-March 2013, third: September-October 2013, fourth: February 2014), between 9:00 am, and 11:00 am. No sampling was conducted during or immediately after rain due to a reduction in ant activity under wet conditions. All ants collected 
were identified to genus level (Fayle et al. 2014). We identified specimens to species level where possible and assigned the remainder to morphospecies. Ant abundance per species at a given site was defined as the mean of the maximum number of each species on each plate (at any time measurement) used at a site (over the whole survey). By taking the mean abundance from the maximum at any given time during the surveys we took into account the possibility of competition that could disadvantage subdominant species if only looking at the abundance after 60 minutes. A protein/carbohydrate preference ratio was defined for each ant species by dividing the total abundance of the species counted at the protein baits (tuna) by the total abundance of the species at both baits (higher ratio indicates increased predator abundance). A communityweighted mean (CWM) of the preference ratio was then determined for each site as an indicator of predator abundance at the site.

\section{Statistical analysis}

We used LMEs to determine the effect of vegetation type on ant species richness, ant abundance and the community-weighted mean (CWM) of the protein/carbohydrate preference ratio, with region specified as a random effect. When the LME contained a significant effect of land-use system on the response variable, we performed a Tukey post-hoc test (with Bonferroni correction) to test for significant pair-wise differences among land-use systems. To meet assumptions of normality all ant abundance was log transformed prior to analysis. LMEs and post-hoc tests were conducted using the nlme (Pinheiro et al., 2015) and multcomp (Hothorn et al., 2008) packages in R 3.2.0 (R Core Team, 2015).

\section{Assessing dummy caterpillar predation rate}

Initially the caterpillar was divided into five sections, (excluding the part of the caterpillar which was glued to the leaf), three rectangular with an area of $3.96 \mathrm{~cm}^{2}$ (25.7\%) and two circular with 
an area of $1.77 \mathrm{~cm}^{2}$ (11.5\%) (Figure 1a). Percentage marked by each predator type was estimated by overlaying marked transparent plastic over each section (Figure A3). Total predation rate for each predator type was calculated for each dummy caterpillar by adding together all sections.

\section{References}

Fayle, T.M., Yusah, K.M., Hashimoto, Y., 2014. Key to the ant genera of Borneo in English and Malay.

Hothorn, T., Bretz, F., Westfall, P., 2008. Simultaneous inference in general parametric models. Biom. J. 50, 346-363.

Pinheiro, J., Bates, D., DebRoy, S., Sarkar, D., R Core Team, 2015. nlme: Linear and nonlinear mixed effects models, R package version 3.1-120. R package version 3.1-120.

R Core Team, 2015. R: A Language and Environment for Statistical Computing. R Foundation for Statistical Computing, Vienna, Austria.

Wielgoss, A., Tscharntke, T., Buchori, D., Fiala, B., Clough, Y., 2010. Temperature and a dominant dolichoderine ant species affect ant diversity in Indonesian cacao plantations. Agric.

Ecosyst. Environ. 135, 253-259. doi:10.1016/j.agee.2009.10.003 
Table A1. Linear mixed effect model ANOVA outputs testing for a significant effect of vegetation type on ant communities. The linear mixed effects models determined the effect of vegetation type on (a) ant species richness, (b) ant abundance, and (c) community-weighted mean (CWM) of the protein/carbohydrate preference ratio (Ant P/C ratio). Significant p-values are indicated in bold $(\mathrm{p} \leq 0.05)$.

\begin{tabular}{llrrc}
\hline Response variable & Effect & df & F-value & p-value \\
\hline (a) Ant species richness & Vegetation type & 27 & 8.73 & $<\mathbf{0 . 0 1}$ \\
(b) Ant abundance & Vegetation type & 27 & 14.24 & $<\mathbf{0 . 0 1}$ \\
(c) Ant P/C ratio & Vegetation type & 27 & 5.44 & $<\mathbf{0 . 0 1}$ \\
\hline
\end{tabular}


Table A2. Summary statistics of Tukey post-hoc tests testing for significant differences in ant communities among vegetation types. Tukey post-host tests determined the response of (a) ant species richness, (b) ant abundance, and (c) community-weighted mean (CWM) of the protein/carbohydrate preference ratio (Ant P/C ratio) to vegetation type. Significant p-values are indicated in bold (Tukey's HSD, $\mathrm{p} \leq 0.05$ ).

\begin{tabular}{lrrr}
\hline Response variable & Estimate & z-value & p-value \\
\hline Ant species richness & & & \\
J - F & -0.50 & -0.38 & 1.00 \\
O- F & 5.25 & 4.02 & $<\mathbf{0 . 0 1}$ \\
R - F & 3.25 & 2.49 & 0.08 \\
O- J & 5.75 & 4.40 & $<\mathbf{0 . 0 1}$ \\
R - J & 3.75 & 2.87 & $\mathbf{0 . 0 3}$ \\
R - O & -2.00 & -1.53 & 0.76 \\
Ant abundance & & & \\
J - F & 0.44 & 1.77 & 0.46 \\
O-F & 1.55 & 6.25 & $<\mathbf{0 . 0 1}$ \\
R - F & 0.44 & 1.76 & 0.47 \\
O- J & 1.11 & 4.48 & $<\mathbf{0 . 0 1}$ \\
R - J & -0.00 & -0.00 & 1.00 \\
R - O & -1.11 & -4.48 & $<\mathbf{0 . 0 1}$ \\
Ant P/C ratio & & & \\
J - F & -0.05 & -1.45 & 0.89 \\
O-F & -0.12 & -3.76 & $<\mathbf{0 . 0 1}$ \\
R - F & -0.02 & -0.61 & 1.00 \\
O- J & -0.07 & -2.32 & $\mathbf{0 . 0 1}$ \\
R - J & 0.03 & 0.84 & 1.00 \\
R - O & 0.10 & 3.15 & $\mathbf{0 . 0 1}$ \\
\hline
\end{tabular}


Figure A1. Study site location and study design. Map of study area located in the Sarolangun (C) and Batanghari (D) regencies in Jambi Province (B), Sumatra, Indonesia (A). In the two study regions, each border type was replicated four times. The study area coordinates were aligned on Bing Map (A \& B), (C NAVTEQ, 2010 and (c Microsoft Corporation, 2016; while others on Google Map (C \& D), ㅇ TerraMetrics, 2016.
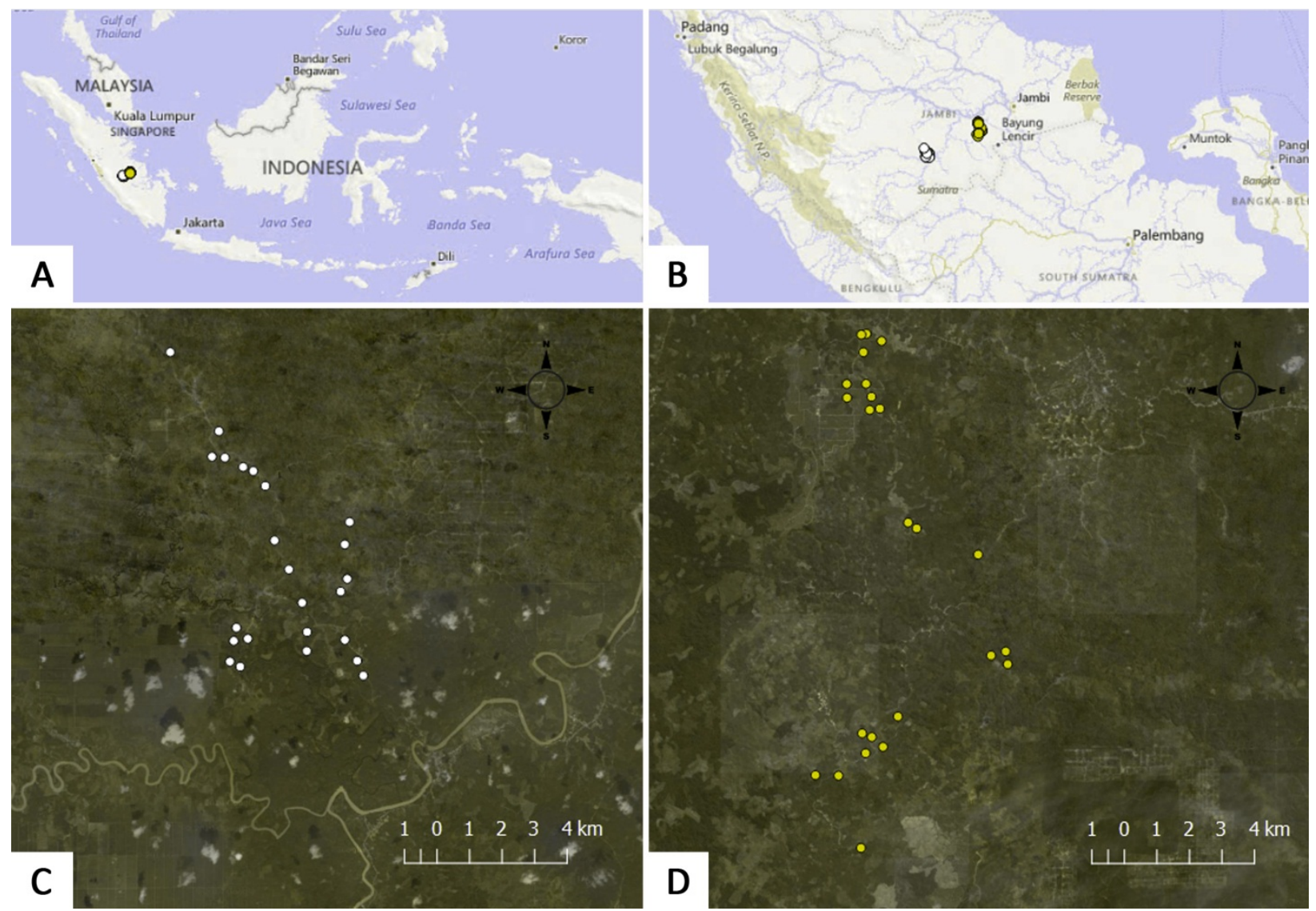
Figure A2. Experimental design. a) dummy caterpillar and exposed prey were attached on the frond; b) each location of the caterpillars were labeled using waterproof marker; c) Every frond with the caterpillar on them was marked with color tape in order to find them easily; d) Inside the border, right side was used for artificial caterpillar and left side was used for exposed prey; e) the arrangement of camera trap in some study sites; f \& g) a dummy caterpillar and a mealworm larvae with labels inside the plantation; h \& i) a dummy caterpillar and a mealworm larvae with labels inside the border; and j) the location of dummy caterpillar and exposed prey on a frond
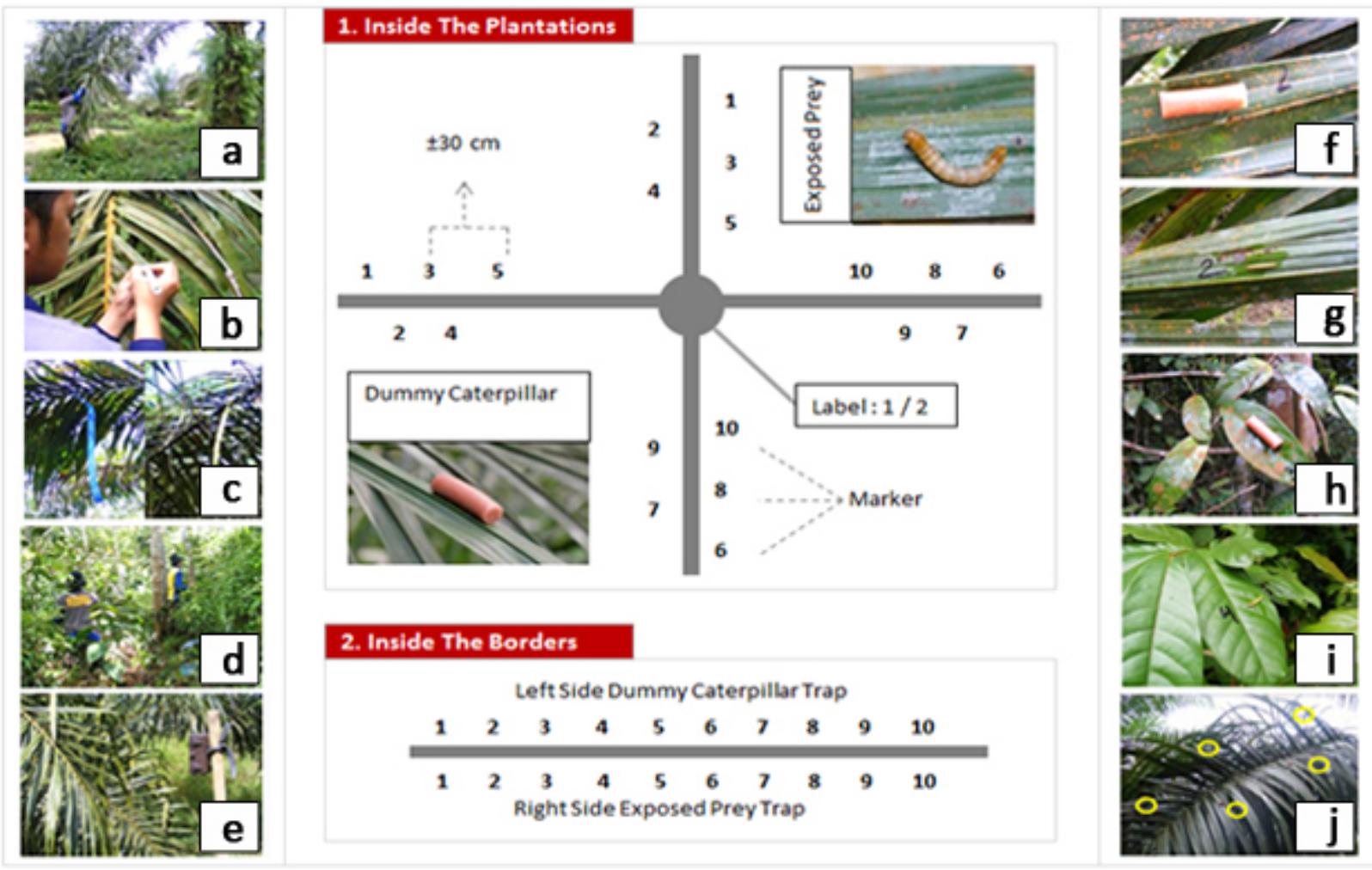
Figure A3. Method for quantifying predation rate on dummy caterpillars. (a) Each caterpillar was divided into five sections for assessment. (b) Marked transparent plastic was overlayed on each section to help assess percentage marked by predators.

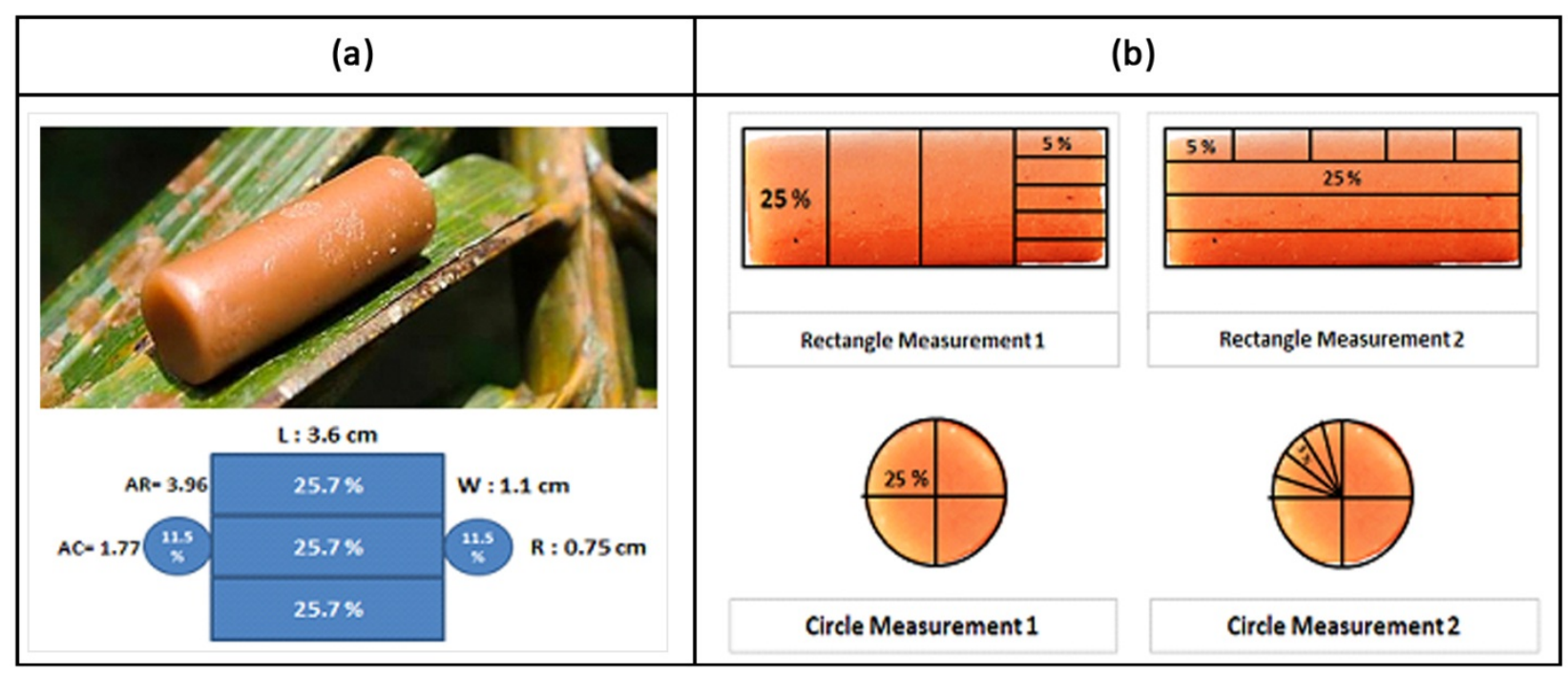




\section{Appendix B. Supplementary result tables}

\section{Table B1. AIC table for comparison of fit of LMEs testing the influence of border type and}

location on predation rate. For both (a) ant and (b) Orthoptera predation rate and we fitted four models with all combinations of explanatory variables, with $\mathrm{df}$ (degrees of freedom) in the model), AIC and $\triangle \mathrm{AIC}$. The best supported models are indicated in bold.

\begin{tabular}{lccc}
\hline \multicolumn{1}{c}{ Response variable } & df & AIC & $\Delta$ AIC \\
\hline (a) $\quad$ Ant predation rate & $\mathbf{2 0}$ & $\mathbf{- 1 7 4 . 6 3}$ & $\mathbf{0 . 0 0}$ \\
Border type*Location & 10 & -173.82 & 0.81 \\
Border type+location & 8 & -161.42 & 13.20 \\
Border type & 5 & -159.27 & 15.36 \\
Location & & & \\
Orthoptera predation rate & $\mathbf{2 0}$ & $\mathbf{- 1 4 2 . 9 1}$ & $\mathbf{0 . 0 0}$ \\
Border type*Location & 10 & -140.91 & 2.00 \\
Border type+location & 8 & -136.12 & 6.79 \\
Border type & 5 & -135.95 & 6.96 \\
Location & 5 & & \\
\end{tabular}


Table B2. AIC table for comparison of fit of LMEs testing the influence of border type and location on predator occurrences. For (a) no damage and damage by (b) solitary ants, (c) Orthoptera, and (d) group of ants, we fitted four models with all combinations of explanatory variables, with df (degrees of freedom) in the model, AIC and $\triangle$ AIC. The best supported models are indicated in bold. Predator occurrences were assigned based on percent damage of mealworm prey items.

\begin{tabular}{|c|c|c|c|c|}
\hline & Response variable & df & AIC & $\Delta \mathrm{AIC}$ \\
\hline \multirow[t]{5}{*}{ (a) } & No damage (0\% damage) & & & \\
\hline & Location & 5 & 100.51 & 0.00 \\
\hline & Border type + Location & 9 & 103.74 & 3.23 \\
\hline & Border type & 7 & 105.37 & 4.86 \\
\hline & Border type * Location & 17 & 108.00 & 7.49 \\
\hline \multirow[t]{5}{*}{ (b) } & Solitary ant (20\% damage) & & & \\
\hline & Location & 5 & 57.06 & 0.00 \\
\hline & Border type + Location & 9 & 62.87 & 5.81 \\
\hline & Border type * Location & 17 & 67.71 & 10.65 \\
\hline & Border type & 7 & 68.93 & 11.88 \\
\hline \multirow[t]{5}{*}{ (c) } & Orthoptera (40 - 80\% damage) & & & \\
\hline & Location & 5 & 59.65 & 0.00 \\
\hline & Border type + Location & 9 & 67.03 & 7.38 \\
\hline & Border type * Location & 17 & 75.96 & 16.30 \\
\hline & Border type & 7 & 78.36 & 18.71 \\
\hline \multirow[t]{5}{*}{ (d) } & Group of ants (100\% damage) & & & \\
\hline & Location & 5 & 64.54 & 0.00 \\
\hline & Border type + Location & 9 & 69.19 & 4.65 \\
\hline & Border type * Location & 17 & 79.39 & 14.85 \\
\hline & Border type & 7 & 80.45 & 15.91 \\
\hline
\end{tabular}


Table B3. Linear mixed effect model ANOVA outputs testing for a significant effect of border type, location and their interaction on predation rates. The best-fit linear mixed effect models which determined the effect of border type, location and their interaction on (a) ant and (b) Orthoptera predation rates on dummy caterpillars (Tables S1). Significant p-values (p $\leq 0.05)$ are also indicated in bold.

\begin{tabular}{llrrr}
\hline Response variable & Effect & df & F-value & p-value \\
\hline (a) Ant predation rate & Border type & 5 & 5.61 & $<\mathbf{0 . 0 1}$ \\
& Location & 2 & 9.71 & $<\mathbf{0 . 0 1}$ \\
& Border type*location & 10 & 2.03 & $\mathbf{0 . 0 4}$ \\
(b) Orthoptera predation rate & Border type & 5 & 3.07 & $\mathbf{0 . 0 2}$ \\
& Location & 2 & 5.06 & $\mathbf{0 . 0 1}$ \\
& Border type*location & 10 & 2.16 & $\mathbf{0 . 0 3}$ \\
\hline
\end{tabular}


Table B4. Summary statistics of glht post-hoc tests testing for significant differences in predation rates between border types within a location. Glht post-host tests determined the response of (a) ant and (b) Orthoptera predation rate on dummy caterpillars to border type at each location. Significant $\mathrm{p}$-values are indicated in bold $(\mathrm{p} \leq 0.05)$. JR $=$ Jungle rubber, WOP=Weedy oil palm, WR=Weedy Rubber, SF=Secondary Forest, SC=Scrub, and Control=Oil Palm Border.

\begin{tabular}{lrrr}
\hline Response variable & Estimate & z-value & p-value \\
\hline (a) $\quad$ Ant predation rate & 0.23 & 3.37 & $\mathbf{0 . 0 1}$ \\
JR.IN50 - Control.IN50 & 0.19 & 2.89 & $\mathbf{0 . 0 4}$ \\
WOP.IN50 - Control.IN50 & 0.15 & 2.20 & 0.25 \\
WR.IN50 - Control.IN50 & 0.21 & 3.14 & $\mathbf{0 . 0 2}$ \\
SF.IN50 - Control.IN50 & 0.10 & 1.56 & 0.69 \\
SC.IN50 - Control.IN50 & 0.31 & 4.61 & $<\mathbf{0 . 0 1}$ \\
JR.IN20 - Control.IN20 & 0.23 & 3.41 & $<\mathbf{0 . 0 1}$ \\
WOP.IN20 - Control.IN20 & 0.20 & 2.97 & $\mathbf{0 . 0 3}$ \\
WR.IN20 - Control.IN20 & 0.17 & 2.59 & 0.10 \\
SF.IN20 - Control.IN20 & 0.08 & 1.23 & 0.90 \\
SC.IN20 - Control.IN20 & 0.38 & 5.66 & $<\mathbf{0 . 0 1}$ \\
JR.OUT20 - Control.OUT20 & 0.24 & 3.52 & $<\mathbf{0 . 0 1}$ \\
WOP.OUT20 -Control.OUT20 & 0.21 & 3.11 & $\mathbf{0 . 0 2}$ \\
WR.OUT20 -Control.OUT20 & 0.11 & 1.59 & 0.67 \\
SF.OUT20 - Control.OUT20 & 0.19 & 2.79 & 0.06
\end{tabular}

(b) Orthoptera predation rate

$\begin{array}{llll}\text { JR.IN50 - Control.IN50 } & 0.09 & 1.09 & 0.92 \\ \text { WOP.IN50 - Control.IN50 } & 0.10 & 1.19 & 0.87 \\ \text { WR.IN50 - Control.IN50 } & 0.19 & 2.16 & 0.24 \\ \text { SF.IN50 - Control.IN50 } & 0.21 & 2.45 & 0.12 \\ & & & 101\end{array}$




\begin{tabular}{lccc} 
SC.IN50 - Control.IN50 & 0.07 & 0.81 & 0.99 \\
JR.IN50 - Control.IN20 & 0.12 & 1.36 & 0.77 \\
WOP.IN20 - Control.IN20 & 0.10 & 1.16 & 0.89 \\
WR.IN20 - Control.IN20 & 0.33 & 3.80 & $<\mathbf{0 . 0 1}$ \\
SF.IN20 - Control.IN20 & 0.35 & 3.94 & $<\mathbf{0 . 0 1}$ \\
SC.IN20 - Control.IN20 & 0.12 & 1.42 & 0.72 \\
JR.OUT20 - Control.OUT20 & 0.29 & 3.26 & $\mathbf{0 . 0 1}$ \\
WOP.OUT20 - Control.OUT20 & 0.13 & 1.44 & 0.70 \\
WR.OUT20 - Control.OUT20 & 0.28 & 3.15 & $\mathbf{0 . 0 1}$ \\
SF.OUT20 - Control.OUT20 & 0.23 & 2.66 & 0.07 \\
SC.OUT20 - Control.OUT20 & 0.08 & 0.90 & 0.97 \\
\hline
\end{tabular}


Table B5. Linear mixed effect model ANOVA outputs testing for a significant effect of

location on predator occurrence. The best-fit linear mixed effect models which determined the effect of location on (a) no predator occurrence and predation by (b) solitary ants, (c) Mantodea and Orthoptera, and (d) group of ants. Significant $\mathrm{p}$-values $(\mathrm{p} \leq 0.05)$ are also indicated in bold. Predator occurrences were assigned based on percent damage of mealworm prey items (see Results).

\begin{tabular}{llrrr}
\hline Response variable & Effects & df & F-value & p-value \\
\hline (a) No predator (0\% damage) & Location & 2 & 2.84 & 0.06 \\
(b) Solitary ants (20\% damage) & Location & 2 & 5.23 & $<\mathbf{0 . 0 1}$ \\
(c) Orthoptera (40 - 80\% damage) & Location & 2 & 8.23 & $<\mathbf{0 . 0 1}$ \\
(d) Groups of ants (100\% damage) & Location & 2 & 8.19 & $<\mathbf{0 . 0 1}$
\end{tabular}


Table B6. Summary statistics of glht post-hoc tests testing for significant differences in predator occurrences between locations. Glht post-host tests determined the response of (a) no predator occurrence, (b) solitary ants, (c) Mantodea and Orthoptera, and (d) groups of ants.

Significant are indicated in bold ( $\mathrm{p} \leq 0.05$ ). Predator occurrences were assigned based on percent damage of mealworm prey items (see Results).

\begin{tabular}{|c|c|c|c|c|}
\hline \multicolumn{2}{|c|}{ Response variable } & \multirow[t]{2}{*}{ Estimate } & \multirow[t]{2}{*}{ z-value } & \multirow[t]{2}{*}{ p-value } \\
\hline (a) & No predators ( $0 \%$ damage) & & & \\
\hline & OUT20 - IN20 & -0.17 & -2.34 & 0.05 \\
\hline & OUT20 - IN50 & -0.12 & -1.68 & 0.21 \\
\hline & IN20 - IN50 & 0.05 & 0.66 & 0.79 \\
\hline \multirow[t]{4}{*}{ (b) } & Solitary ants (20\% damage) & & & \\
\hline & OUT20 - IN20 & -0.20 & -3.27 & $<0.01$ \\
\hline & OUT20 - IN50 & -0.09 & -1.50 & 0.29 \\
\hline & IN20 - IN50 & 0.11 & 1.77 & 0.18 \\
\hline \multirow[t]{4}{*}{ (c) } & Orthoptera (40 - 80\% damage) & & & \\
\hline & OUT20 - IN20 & -0.15 & -2.66 & 0.02 \\
\hline & OUT20 - IN50 & -0.22 & -4.04 & $<0.01$ \\
\hline & IN20 - IN50 & -0.08 & -1.38 & 0.35 \\
\hline \multirow[t]{4}{*}{ (d) } & Groups of ants (100\% damage) & & & \\
\hline & OUT20 - IN20 & 0.23 & 3.94 & $<0.01$ \\
\hline & OUT20 - IN50 & 0.17 & 2.95 & $<0.01$ \\
\hline & IN20 - IN50 & -0.06 & -1.00 & 0.58 \\
\hline
\end{tabular}




\section{Part 4}

\section{Landscape Context of Oil Palm Plantations affects Biocontrol Pressure: A Model}

Fuad Nurdiansyah, Jan Salecker, Johannes Heinonen, Yann Clough,

Teja Tscharntke, and Kerstin Wiegand 


\begin{abstract}
We investigate the effect of landscape context by simulating three different landscape-driven factors on predation pressure: border type, plantation size and shape. Based on field data from Chapter 3, data analysis using linear regression was performed and an agent-based model was developed to address two specific objectives: 1). Investigating the effects of the landscape context on the predation pressure inside the plantation, 2). Evaluating strategies of sustainable pest control via oil palm landscape management. Model results showed that landscape complexity was the major influence on the predation pressure. Under complex arrangements of vegetation surrounding the oil palm plantation, predation pressure inside the plantation might even double. Increasing plantation size led to considerable decrease in predation pressure by up to $50 \%$, while narrowing the plantation compensated predation pressure by about $20 \%$. The effect of landscape context which potentially increased the pressure were only limited in the plantation sizes between 50 - 100 ha, suggesting higher potential pest attacks in the plantation higher than the sizes. Thus, a good strategy for sustainable pest control in the plantation might be to retain higher vegetation surrounding the plantation, to develop small and narrow plantations in order to have high predation pressure. Further studies on growing weedy-flowering plants as crop understory might help to distribute and increase the pest pressure inside relatively bigger plantations.
\end{abstract}

\title{
Keywords
}

Biodiversity Loss, Ecosystem Function, Sustainable Pest Control, Agent-Based Model, NetLogo 


\section{Introduction}

The world's most cultivated and used vegetable oil, palm oil (Koh and Ghazoul, 2008), is being evaluated on how to optimize the trade-off between increasing crop production and conserving biodiversity (Koh and Wilcove, 2007; Turner et al., 2008). Great expansion of big oil palm plantations that have been transformed from natural habitat (Phalan et al., 2013), results in huge biodiversity losses and alteration of species assemblages, especially of species at higher trophic levels (Chung et al., 2000; Donald, 2004; Fitzherbert et al., 2008). Even though worldwide international communities are highly concerned about the adverse effects of the transformation of natural habitats on the global ecosystem (Phalan et al., 2013), the plantation expansion in the topmost oil palm-producing countries, Indonesia and Malaysia (80 - 90\% of worldwide palm oil production) (“FAOSTAT," 2016), still continues and is expected to increase further in the future (Fitzherbert et al., 2008). Most studies on the topic report on conservation strategies and mitigation processes which might not have direct economic benefit for the oil palm farmers (Foster et al., 2011; Savilaakso et al., 2014). The loss of biodiversity due to plantation expansion does affect several ecosystem functions, such as pest control, pollination and soil processes (Dislich et al, in revision). Investigations on these functions might draw the farmers' attention because the reduction of these ecosystem functions might directly affect their income and the sustainability of their plantations (Savilaakso et al., 2014; Tscharntke et al., 2005). Lack of empirical evidence on these topics also obstructs the development of eco-friendly plantations around the world. In addition, given the low law enforcement and lack of experience of farmers regarding environmental concerns, oil palm plantation area continues to expand without much consideration of the plantation sustainability (McCarthy and Zen, 2010; Obidzinski et al., 2012). 
Biological control (short: biocontrol) is an economically important ecosystem function and has been recognized to be negatively affected by the loss of biodiversity. Defoliating pests, mainly bagworms (Psychidae) and nettle caterpillars (Limacodidae), were recognized as the most damaging pests of the oil palm crop (Wood, 2002). A previous study by Basri et al. (1995) shows that the predatory beetle, Callimerus arcufer (Coleoptera: Cleridae), is a potential predator of the bagworm, Metisa plana Walker (Lepidoptera: Psychidae) (Basri et al., 1995). Another study found a species of exotic tramp ants, Anoplolepis gracilipes, the yellow crazy ant, could be a potential biocontrol agent because this species has successfully been used in several cocoa and coconut plantations to control herbivore pests (Way and Khoo, 1992). However, some studies reported reductions of predatory beetle abundance and richness of about $50.2 \%$ and $22.7 \%$ respectively as well as a decreased predatory ant species composition in general during the landused change from natural habitat to oil palm plantations, a loss which might increase the risk of pest attacks in the plantations (Chung et al., 2000; Denmead et al. in prep.).

Management practices of monoculture plantations often create unfavorable conditions for local survival of biocontrol agents such as predatory birds, ants, and beetles (Foster et al., 2011; Senior et al., 2013). Known sustainable pest management of the oil palm crop typically use biocontrol approaches as their main application (Bakeri et al., 2009; Kamarudin and Wahid, 2010; Zeddam et al., 2003). However, rather than conserving native biocontrol agents in the field, inundative methods of exotic biocontrol agents are widely applied by oil palm farmers when dealing with attacks by herbivorous pests (Bakeri et al., 2009; Zeddam et al., 2003), due to lack of information on native biocontrol agent-conservation methods (Savilaakso et al., 2014).

One of the key obstacles to conservation of biocontrol agents is a good understanding of landscape contexts (Bianchi et al., 2006; Tscharntke et al., 2007). As for many agricultural land- 
use systems, understanding of landscape context is rare for oil palm plantations. Ongoing discussions on biocontrol conservation in the plantation suggest to retain vegetation surrounding plantations (Koh, 2008a), to retain or plant weedy-flowering plants as understory (Koh, 2008b; Koh et al., 2009) and to riparian forest fragments (Gray and Lewis, 2014), even though direct investigation on the relative importance of the landscape management on biocontrol is not known yet (Foster et al., 2011; Savilaakso et al., 2014). A study by Nurdiansyah et al. in preparation (Dissertation Chapter Three) investigated different vegetation types around plantations and the effect of those surroundings on the native biocontrol pressure in the plantation. In this study, predatory ants have been identified as the main predator of dummy caterpillars representing the caterpillar pest Sethotosea asigna. Nurdiansyah et al. (in preparation) found that predation pressure in the plantation depends on both the type of the bordering vegetation and the distance to the plantation border. Thus, they suggest to retain rich vegetation surrounding the plantations combined with weedy-flowering plant-strips as a plantation corridor in order to preserve higher predator pressure throughout the plantation. However, the study by Nurdiansyah et al. (in preparation) was limited by measuring only the predator pressure relative to one side of the plantation and by observing the predation at short distances to the border only. There are still needs for further investigations on the effects of more complex landscape settings and of larger spatial scales.

Information of predation pressure distribution for larger distances to the plantation border will give more insight knowledge of the landscape context effects, but it is hard to be performed alone by fieldwork due to difficulties to get proper locations in the field and it requires intensive work for measurements. Here, we use a model to investigate the effect of different vegetation border types on predation pressure in the entire plantation (and not just at locations close to the 
plantation border). In addition, we study scenarios of landscape context where modelled oil palm plantations differ in size and shape. Thus, the objective of the current study was to observe the distribution of predation pressure in the whole plantation area considering different plantation border types, plantation sizes and shapes. For this purpose, the results from the field study by Nurdiansyah et al. (in preparation) were used to develop and parameterize a simulation model. The border type effects were simulated for plantation sizes commonly found in the real field, i.e. ranging from 2.56 ha to 1000 ha. Each of the plantation sizes has three different shape categories, ranging from square to a more narrow shape. The effects of these landscape contexts were assessed based on the main output variable of the model, the average predation pressure within the plantation. 


\section{Methods}

\subsection{Study Background}

The model inputs are based on data of the landscape context effects on the predation pressure in oil palm plantations. Nurdiansyah et al. (in preparation) investigated six different border types that were another oil palm plantation (control), weedy oil palm, weedy rubber, scrub, jungle rubber and secondary forest in Jambi Province, Sumatra, Indonesia. For each site, the predation pressure has been measured at three paired (=six) locations with three different distances (20 m outside, $20 \mathrm{~m}$ inside, $50 \mathrm{~m}$ inside) to the plantation border. Each border type was replicated at eight sites, resulting in a total of 48 sites and 288 locations). At each location, dummy caterpillars were exposed for four days and all marks caused by a predator's mandibles, teeth, beak, or ovipositor were recorded. Predation pressure was expressed as percentage of dummy caterpillar surface area marked by predators and assigned to a predator group. The results show that predator pressure by predatory ants was dominant with a mean predation rate of $24.28 \%$ compared to $37.29 \%$ of the total predation rate by all predators. The study found significant effects of the different border types and distances including their interaction on predation pressure. However, due to the sampling design, the study only investigated the predation pressure relative to one side of the plantation. Thus, here our goal was to expand the observations to whole plantations (each plantation surrounded by one type of bordering vegetation at four sides) and to estimate the effects of different plantation sizes and shapes in order to better understand the effect of the landscape context on predation pressure. 


\subsection{Model Parameterization}

Initially, the whole dataset of the predation pressures were averaged for each border type and distance, OUT 20, IN 20 and IN 50, and analyzed using linear regression analysis. Slope and intercept generated by the analysis were then used as linear equations for each type of border effect (figure 1). The linear equations were used in the model to calculate a predation pressure value for each cell, dependent on the border type and the distance to the nearest border. However, in a second step, these linear equations were modified in order to account for local and global variation, i.e. variation within and between sites. Local variation was assessed by 1) calculating the standard deviation of each pair of locations and 2) averaging across all distances and replications of the same border types (i.e., a mean across 3 x 8 values). Global variation was assessed by 1) taking the average predation pressure for each pair of locations, 2) for each distance (OUT 20, IN 20 and IN 50) and border type, calculating the standard deviation of these pairs across the eight sites and 3) for each border type, taking the average across the three distances. In the model, local variation was used to represent variability within one plantation and global variation was used to represent variability between landscapes with identical landscape settings (due to unidentified reasons). Variations were modelled by drawing from random distributions. Global variation was used to add a global variation level, which equally increases or decreases the predation rate of all cells in the model.

There was special case for secondary forest, where Nurdiansyah et al. (in preparation) found that the predation pressure tended to increase towards the center of the plantation, i.e. with increasing distance to the border, even though this is unlikely happen in the field. Several studies showed no change of ant abundances and species richness within plantations close to forest (Lucey and Hill, 2012), whereas other studies found a decreasing pattern of the ant population 
density inside the plantation (Fayle et al., 2013; Luke et al., 2014; Pfeiffer et al., 2008). However, none of the studies measured the predation pressure in regard to the plantation border vegetation. Thus, due to the unclear pattern of the pressure inside the plantation nearby secondary forest, we simplified the pattern by using a constant predation pressure up to a maximum distance from the border and a sudden drop to the control value. As this maximum distance could not be clearly identified, we ran simulations for three scenarios, i.e. different maximum distances that were $230 \mathrm{~m}$ (SF 230), $500 \mathrm{~m}$ (SF 500) and 1,000 m (SF 1000). 


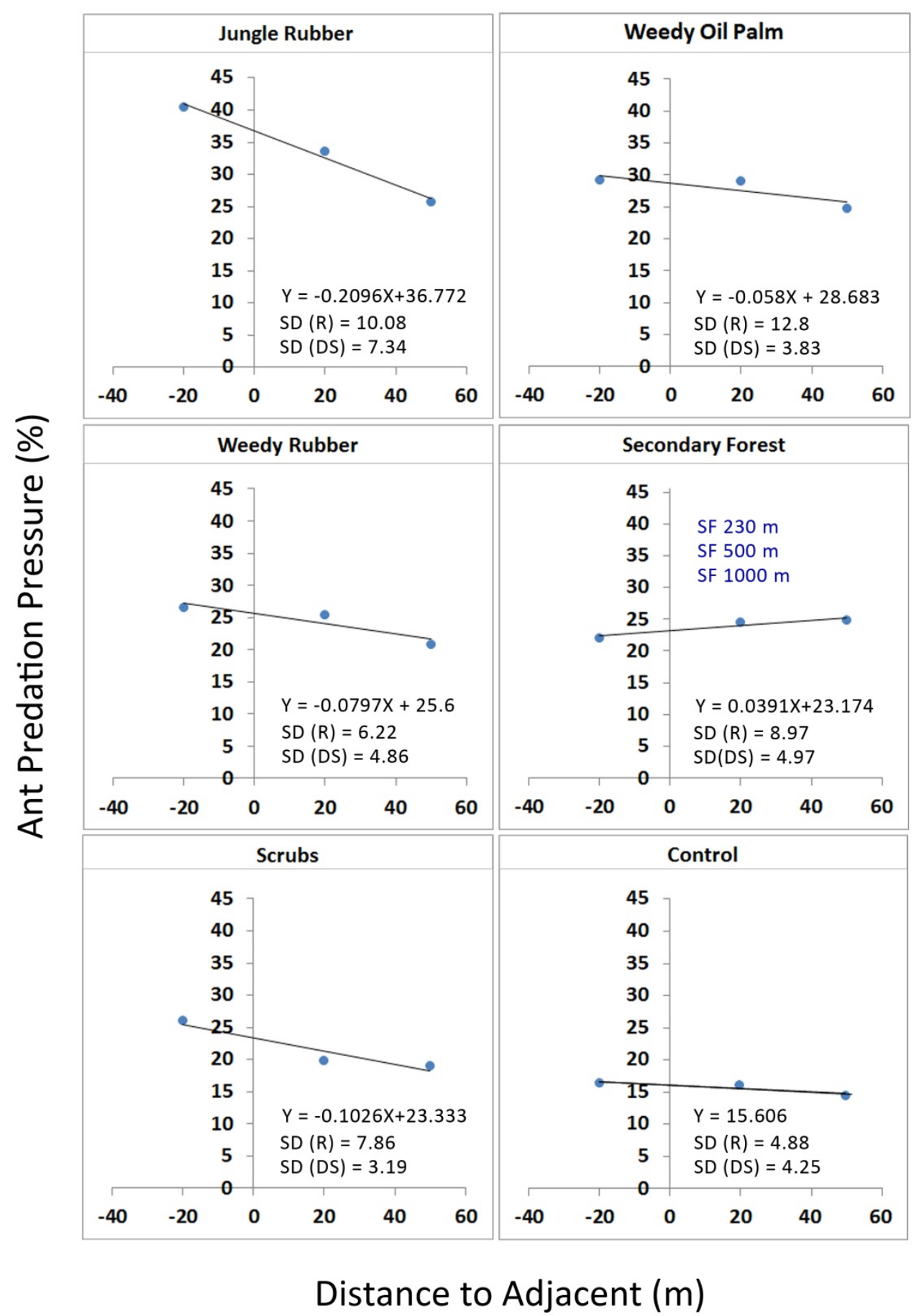

Figure 1. Effect of different border types on the ant predation pressure with increasing distance to the border. Positive distance values represent locations inside the plantation, while negative values represent locations inside the border. Global variation (Standard Deviation Replicate, SDR) is derived from the variation of the border type replicates, and local variation (Standard Deviation Dependent Sample, SDDS) is derived from the variation of dependent samples at the same distances. 


\subsection{Model description}

\subsubsection{Overview}

Purpose - There is limited information on effects of landscape context on biocontrol pressure. Thus, the model was developed to investigate biocontrol in oil palm plantations surrounded by one of six different vegetation types: another oil palm plantation (control), weedy oil palm, weedy rubber, scrub, jungle rubber, and secondary forest. However, rather than measure the pressure from only one side of the plantation and at certain distances to the border, this study observed the predation pressure inside the whole plantation. In this context, the purpose of the study was to answer several questions: 1). How do different border types affect levels of the predator pressure in the entire plantation. 2). Does plantation size and shape influence the predator pressure inside the plantation.

Entities, state variables, and scales -The main entity of the model is an oil palm plantation surrounded by a specific border type (Figure 2). The border types assessed were the jungle rubber, weedy oil palm, weedy rubber, secondary forest, scrubs and control border (oil palm plantation). The plantation and border types were implemented as a grid of cells where each cell represented 10 x 10 meters and the plantation area was measured in hectare (ha). Thus, each cell in the model is characterized by a predation-rate variable to hold the calculated predation pressure values for this cell. Six plantation sizes were implemented: 2.56, 10.24, 51.84, 100.00, 501.75, and 998.56 ha (Figure 3). The sizes represent typical sizes of plantations owned by smallholder farmers, estate or private companies in Indonesia. Three plantation shapes were implemented (Figure 3): a square of side length $a$ (shape 1), a rectangle with side lengths $a / 2$ and $2 \times a$ (shape 2) and narrow rectangle with side lengths $a / 4$ and $4 \times a$ (shape 3 ). The changes of plantation shapes, from shape 1 to shape 3, did not change the area but the shapes made the 
plantation become narrower in order to get more exposure to the border type effects. No temporal dynamics is considered in the model, the values were assigned at a fixed point in time. Process overview and scheduling - In the initialization step, the model sets up the plantation grid followed by setting up the plantation borders (Figure 3). Based on border type effects, the predation pressures $(P R)$ of all cells were determined via the corresponding deterministic linear regression equation and modified both according to the global variation (Standard Deviation Replicate, SDR) and the local variation (Standard Deviation Dependent Sample, SDDS; see also 2.2 Model Parameterization). Using global and local variation the model generated variation between cells which have the same distances. It was assumed that deep inside plantations predator pressure was the same as for plantations surrounded by further oil palm plantations (control border). Thus, at distances beyond the maximum distance of border effects (of a given non-control border type), the control border values were then applied. 


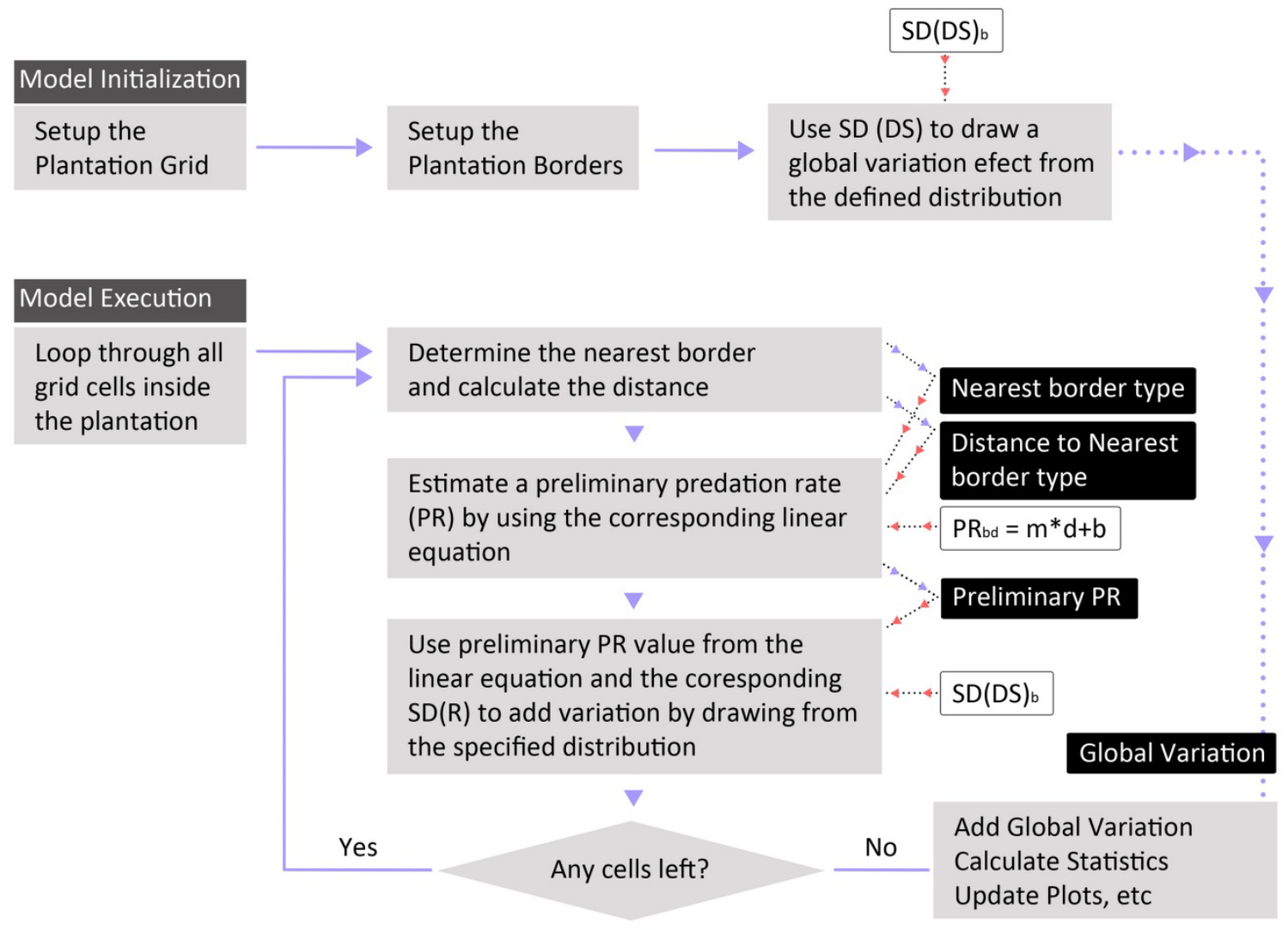

Modeling Step $\square$ Model Process $\square$ Variable $\square$ Parameter

Figure 3. Process and scheduling of the model from initialization to execution steps

\subsubsection{Design Concept}

Basic principles -The existence of the biocontrol agents highly depends on the complexity of the vegetation structure (Barbosa, 1998). Across complex habitat types, forest plays an important role as reservoir of many natural enemies to common pests (Bianchi et al., 2006; Hajek, 2004). However, agricultural areas adjacent to forest fragments are known to have higher predator pressure compared to natural habitat, particularly by birds, mammals and ants, due to higher numbers of prey abundance adjacent to the crop area (Seifert et al., 2016, 2015; Tvardikova and Novotny, 2012) and this results in spillover effects by the predators in the landscape (Bianchi et 
al., 2006; Tscharntke et al., 2007). Thus, here we investigated the effect of six different border types on the predation pressure inside the plantation. Most predator actions of herbivore pests are usually by arthropods, while other predators played a minor role (Seifert et al., 2016). Especially on oil palm crops, the predatory arthropod was ant species (Nurdiansyah, et al. in preparation). Lucey and Hill (2002) found constant ant abundance and species richness in the plantation if forest was present at most at $1 \mathrm{~km}$ distance (Lucey and Hill, 2012). However other studies show a decreasing pattern of ant population abundance inside the plantation with increasing proximity to the border (Fayle et al., 2013; Luke et al., 2014; Pfeiffer et al., 2008). Here, based on the Nurdiansyah et al (in preparation), linear equations were used to calculate ant predation pressure for each cell, dependent of the border type and the distance to the nearest border. The decreasing pattern of the predator pressure inside the plantation was investigated by in the field (Nurdiansyah et al in preparation), but due to some limitations there is need to have more deep understanding on the topic through this model study.

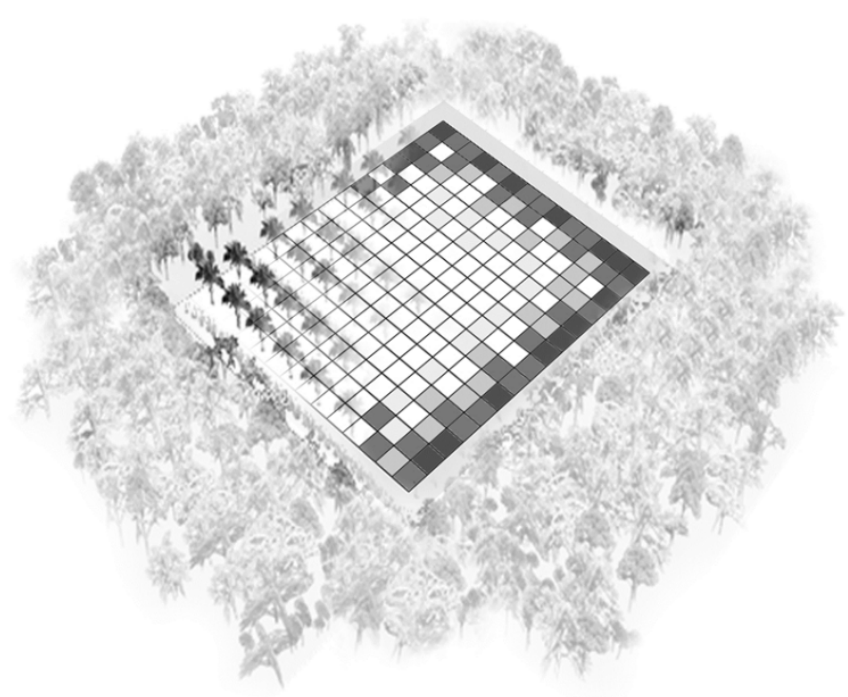

Figure 2. Overview of the model. A synthetic oil palm plantation surrounded by a border of a specified border type. Effects of border type on the predation pressure are represented as grey color in the plantation area $($ dark color $=$ high predation pressure, light color $=$ low predation pressure). 
Stochasticity - Plantations of the same size, shape and border type differ in predation pressure due to global variability. Local cells of a given border type and a given distance to the nearest border differ due to local variability (cf. 2.2 Model parameterization)

Observation - The most important observation is the predation-rate-index, which is the average predation rate across all cells of a plantation. Additional measurements are median predation rate, minimum predation rate, maximum predation rate, standard deviation of predation rates. Additionally a verification of the model was carried out by using the virtual ecologist approach (Zurell et al., 2010). The virtual ecologist function was designed to take samples from the artificial plantation in the same manner as in the field (Nurdiansyah et al. in preparation). The virtual ecologist function took two random samples each at distances $20 \mathrm{~m}$ and $50 \mathrm{~m}$ from the adjacent border (within the plantation). These processes were replicated eight times for each type of border. This allowed the model to imitate the work that has been done in the field and measurement values were processed similar to the field data including calculating the average of each distance and also the corresponding variation (standard deviation). Actually, the "virtual ecologist verification” should ideally be carried out by using a dataset which has not been used for model parameterization, but unfortunately there is no second data set available yet.

\subsubsection{Details}

The modeling process was started by generating a plantation with a defined size and shape and assigning the border-type surrounding the plantation. Then, based on the corresponding regression and local and global variation predation pressure was determined for each plantation cell. An average value of all cell values (predation-rate-index) in the plantation was calculated belong to different border types, sizes and shapes. 


\subsubsection{Simulation parameter settings}

For each combination of border type, plantation size and shape, 500 replicates were run.

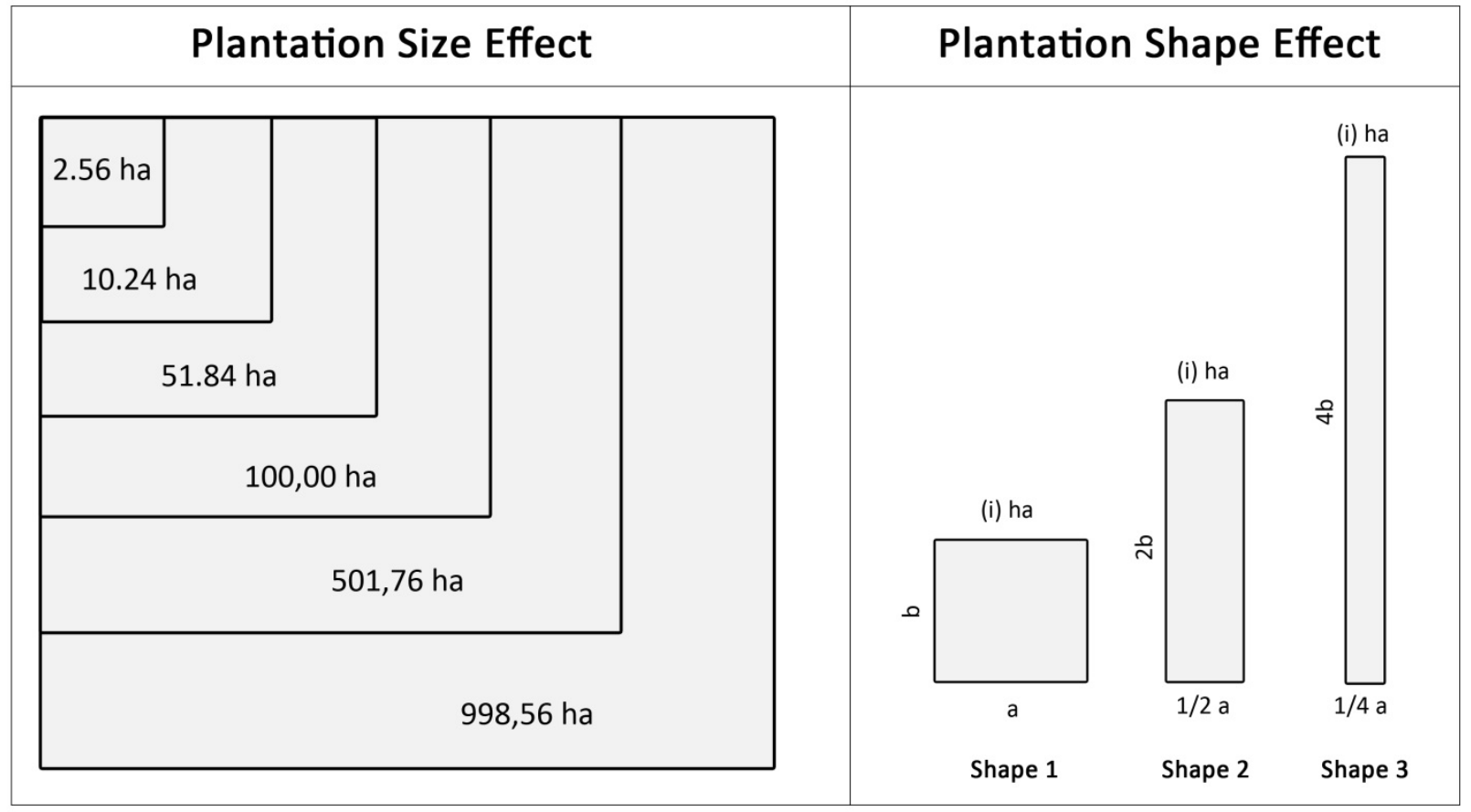

Figure 4. The model investigates plantations of different sizes and shapes.

\subsubsection{Technical details}

The model was implemented in NetLogo version 5.2.0. The NetLogo tool "BehaviorSpace” was used to define and execute the arrangements of different parameters settings. The model result was exported as table with “.csv” file extension using report function "export-predation-value”. The value were then plotted in R 2.13.0 environment (R Development Core Team, 2011) using the ggplot2 (Hadley Wickham and Winston Chang, 2015). 


\section{Results}

\subsection{Model Development Overview}

The simulation of the border type effects on the predation pressure showed that the pressures decreased with increasing distance to the plantation border (Figure 5). The influence of distance of the border differs between border types (represented by different colors in Figure 5). Cells which were not within the influence distance of a border have been filled up with control values (grey color). The variations of the color gradients are caused by the local variation SD (DS), which was embedded in the model to mimic the natural variation in the field.

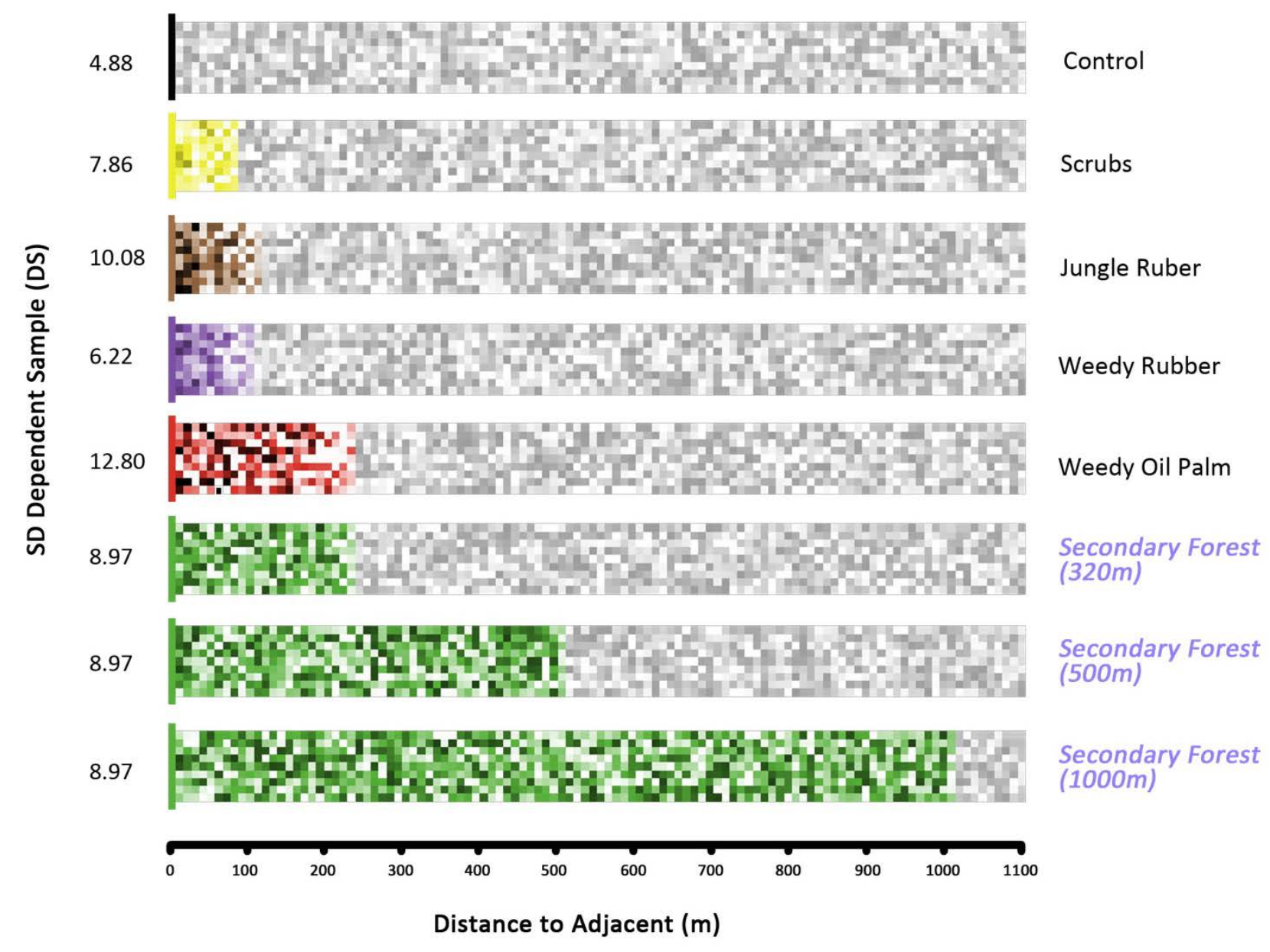

Figure 5. Screenshots of the border type effects inside the plantation. Different colors show different border type effects and color gradation related to $\mathrm{SD}(\mathrm{DS})$ variation where dark color represent higher predation pressure, while light color are lower pressure. 


\subsection{Effects of Landscape Contexts on the Predation Pressure}

The predation pressure decreased in every type of border except control border in conjunction with the transformation of plantation sizes. However, changing the plantation shapes from wide to narrow increased the pressure slightly (Figure 6). The distribution of the data arises from the 500 replicates for each simulation parameter setting. It follows a normal distribution and gives some information about the stochasticity of the model. The border type effects had relatively higher influence in increasing the pressure until intermediate plantation sizes. Moreover, the plantation shapes effects increase the pressure between the small to intermediate plantation size, and small value after the size.

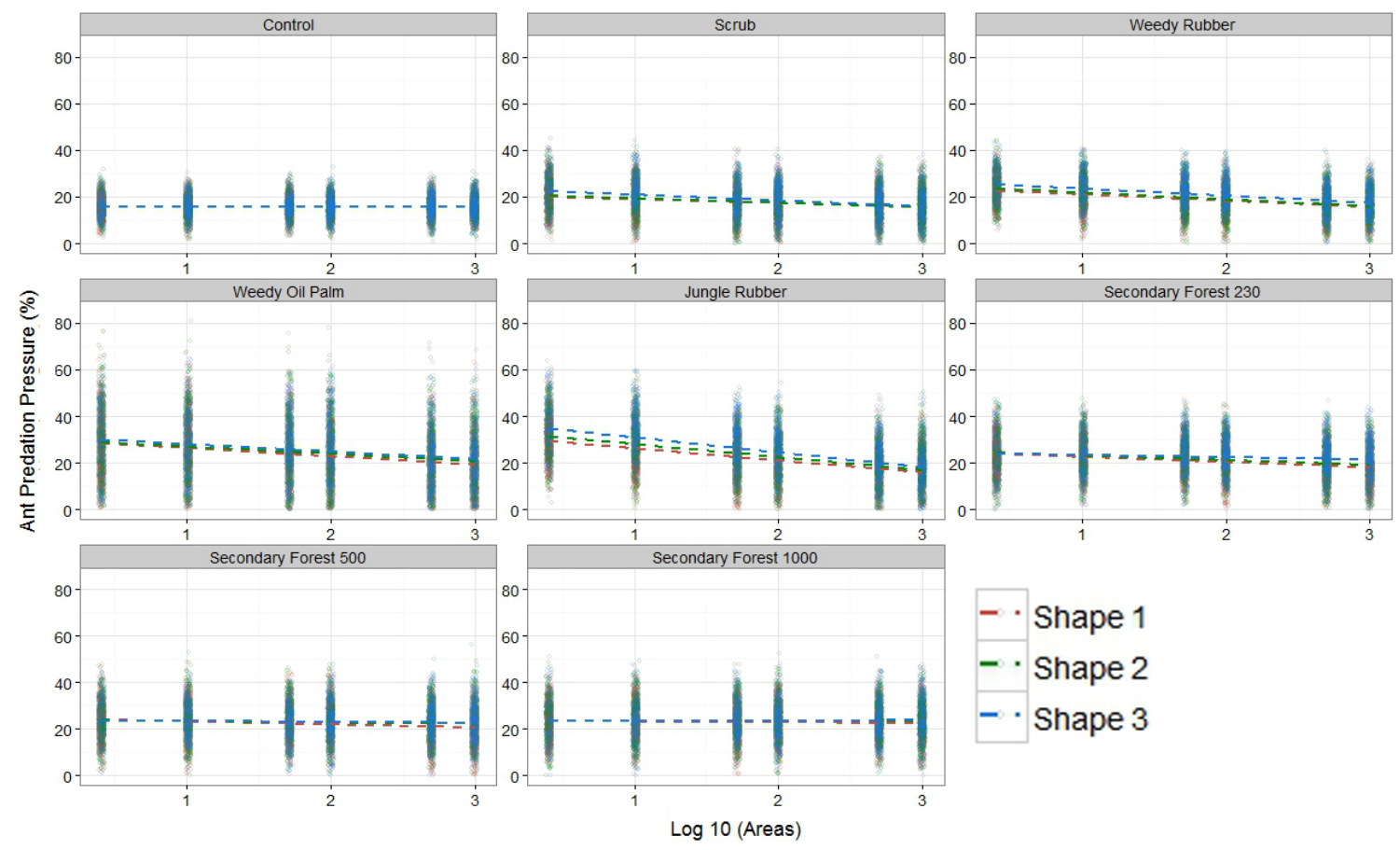

Figure 6. The effect of Landscape contexts, border type, size and shapes, on the ant predation pressure. 500 data replicates in each area were laid overlap for the three shape types. See Figure 4 for an explanation of Shapes 1 - 3. 
To estimate the effects of the border types on the predation pressure inside the plantation, we calculated the predation pressure difference of each border type median to the control median values. The results show higher pressure inside plantations surrounded by complex vegetation habitats (i.e. Jungle rubber, Weedy oil palm, Weedy rubber, Secondary forest and Scrub; Figure 6). Small plantations from 2.56 ha to 10 ha show the highest differences compared to the control. Especially for the Jungle Rubber and the Weedy Oil Palm border, the pressure values were almost doubled, whereas the predation values of other border-types increased up to $150 \%$ of the control values. However, this effect decreases with increasing plantation size. The median pressure values declined nearly to the control value, with different minimum levels for each border type. In scrub and weedy rubber, the median decreased to the control value already at a plantation size of 100 ha, while for others it reached the control value at a size of 1000 ha except for Secondary Forest 500 and Secondary Forest 1000.

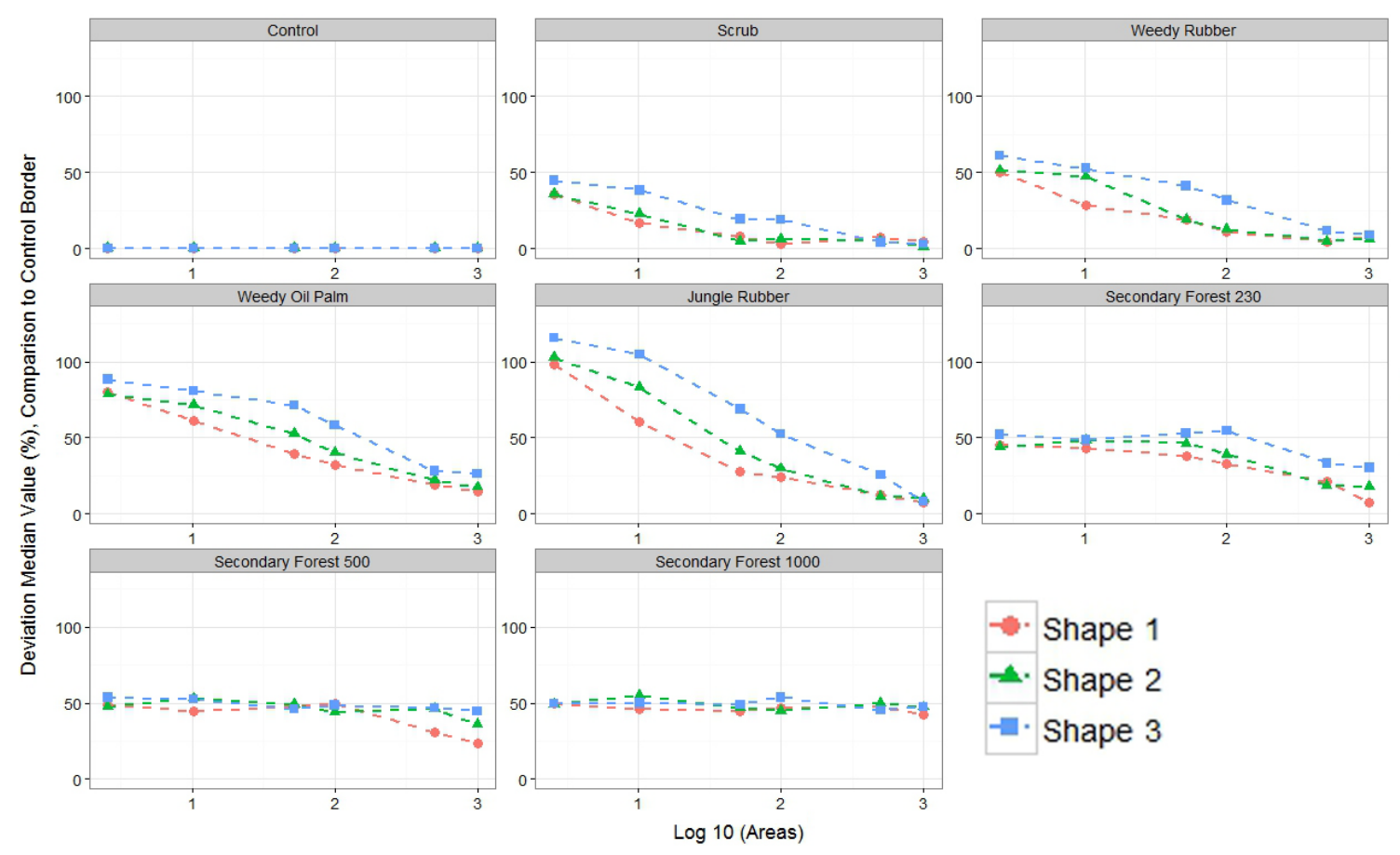

Figure 7. Relative median predation pressure of all border types relative to the control value, for each plantation size. See Figure 4 for an explanation of Shapes 1 - 3. 
To estimate the effects of the plantation size on the predation pressure inside the plantation, we calculated the differences in median predation pressure of each plantation size compared to the median of the smallest plantation (2.56 ha) of the same border type. Except Secondary Forest 500 and Secondary Forest 1000, the predation pressure decreased with increasing plantation size (Figure 8). The highest median predation difference between the smallest (2.56 ha) and biggest (998.56 ha) plantation size was higher than $40 \%$ in jungle rubber and weedy oil palm, whereas in weedy rubber and scrub, the difference was only $20-30 \%$. For all border types but secondary forest border type changing the plantation size until 100 ha size revealed as the sharpest decreases on the pressures.

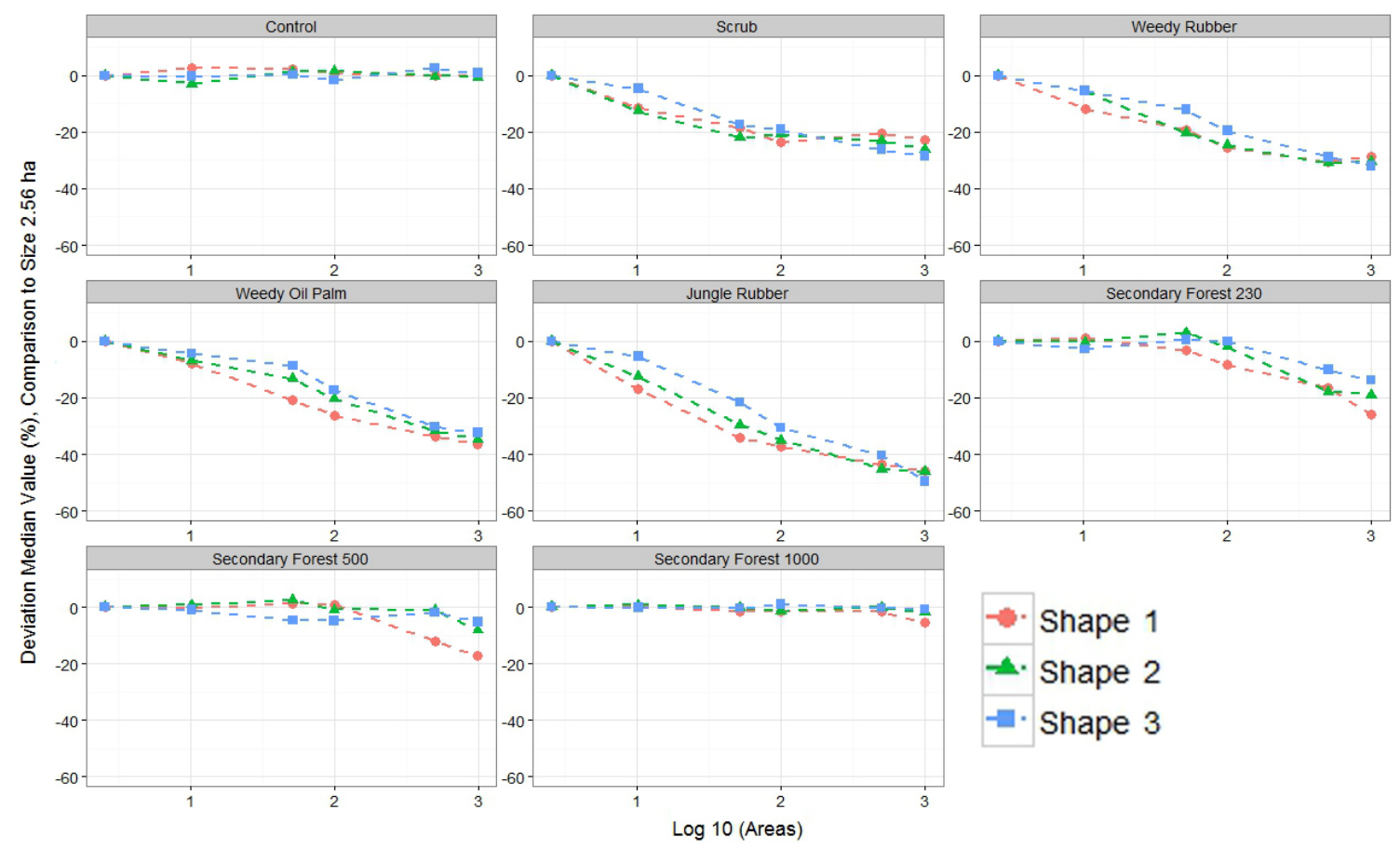

Figure 8. Predation pressure comparison of all plantation sizes to size 2.56 ha in each border type effect. See Figure 4 for an explanation of Shapes 1 - 3. 
To estimate the effects of the plantation shapes on the predation pressure inside the plantation, we calculated the differences of each plantation shape median compared to the median of the rectangular shape (shape 1) of the same size and border type. In narrow plantations, pressures were higher (Figure 9). The highest pressures were found in intermediate size plantations from 10 ha to 100 ha. The shape effect on predation pressure raised by around $20 \%$ for the narrowest plantation shape (shape 3) and up to $10 \%$ for the intermediate plantation shape (shape 2). An interesting pattern was observed for the shape effect of scrub where the deviation decreased for the 50 ha plantation size and increased slightly for the 100 ha plantation size before decline to the rectangular shape value (shape 1). This suggests that the pressure increment was more affected by shape for the 50 ha than the 100 ha plantation size. However, the increments of intermediate plantations sizes surrounded by weedy rubber, show a more homogenous deviation from the rectangular plantation shape (shape 1).

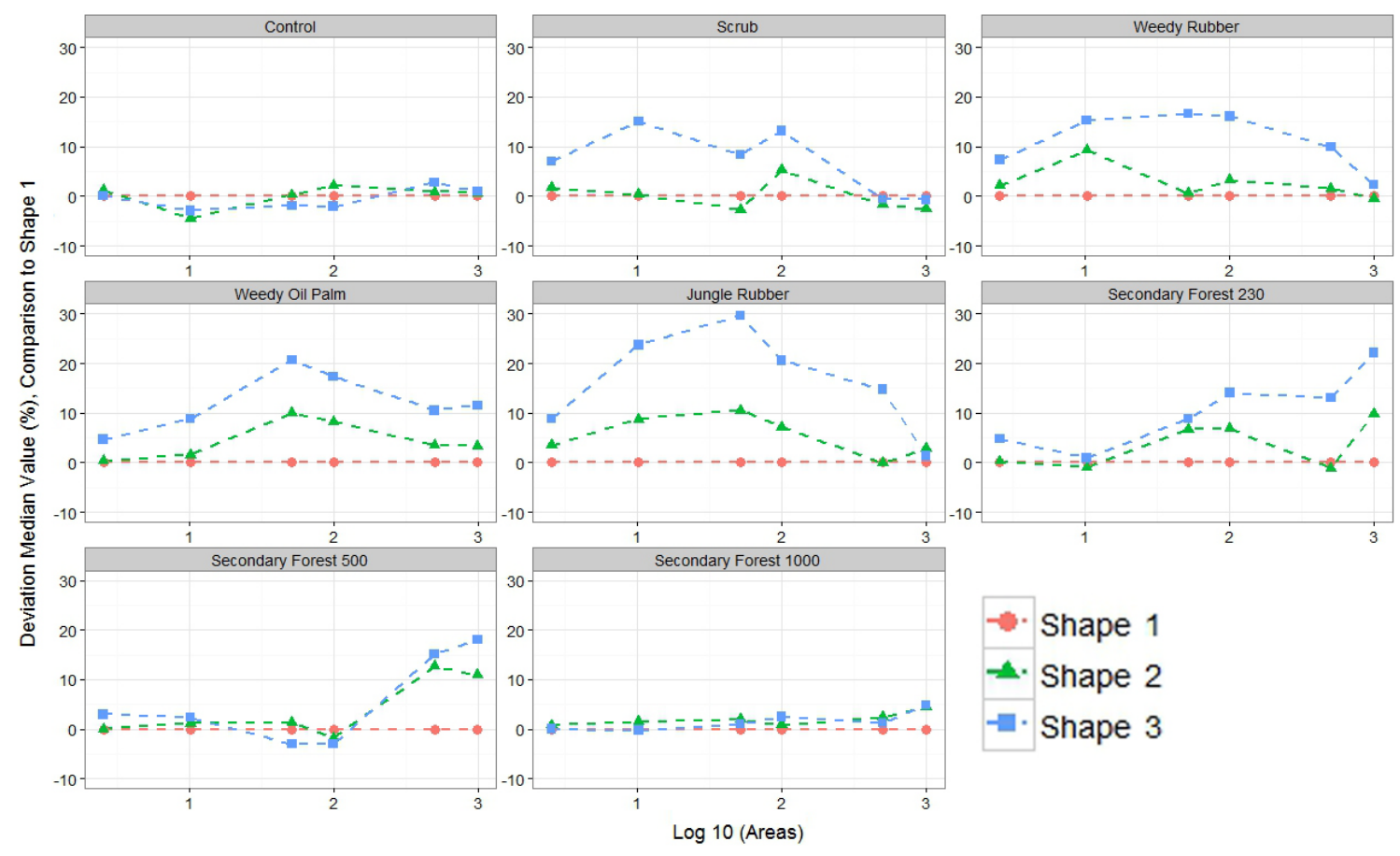

Figure 9. Predation pressure comparison of all shape types to shape 1 in each border type effect. See Figure 4 for an explanation of Shapes 1 - 3. 


\section{Discussion}

The model study enabled us to improve the understanding of the predation pressure dynamics inside the plantation related to the landscape contexts. We found that the distribution of ant predation pressure in the plantation is highly affected by different vegetation surrounding the plantations, plantation sizes and shapes. In general, the strongest effect on the pressure resulted from the border type effect followed by the size and shape effects. The more complex the vegetation of the plantation border was, the higher the predation pressure was inside the plantation, i.e. predation pressure increased in the order Jungle rubber, Weedy oil palm, Weedy rubber, Secondary forest and Scrub. However, with increasing plantation sizes, the pressure dropped sharply from small to intermediate plantation sizes, but a more narrow shape leads to higher pressure inside the plantation. These findings suggest that landscape management could be useful in designing the plantation in regard to conserving high predator pressure inside the plantation and may also contribute to sustainable plantation management in the future, especially in dealing with the pest management.

Non-crop habitat intermingled with agricultural land use increases ecosystem sustainability as it is likely that the habitats might reserve many pest natural enemies (Bianchi et al., 2006). Landscapes simplified by excluding woody or herbaceous habitats as well as by decreasing the patchiness of arable field is frequently declared as the main factor of increasing pest attacks due to lower natural enemies activity (Foster et al., 2011; Tscharntke et al., 2007; Wood, 2002). Here, our results indicate that the pressure could be doubled when the plantation is surrounded by non-crop habitats especially for small to middle sized plantations, from 2.5 ha to 100 ha. Contrary to our results, some studies, which were also using dummy caterpillars for 
measuring predation pressure, showed that the predation pressure was lower in the natural habitats (Seifert et al., 2016; Tvardikova and Novotny, 2012). This might be due to high competition of resources in those habitats where there is always check and balance between natural enemies and pest populations preventing excessive numbers of the organisms (Hajek, 2004; Norris et al., 2003; Wood, 2002). Nevertheless, retaining secondary forest may act as reservoir of many biocontrol agents which could have high pressure in the plantation interior, while developing common remaining habitats in the landscape such as weedy oil palm and rubber as well as jungle rubber also play important role on the pressure within limited plantation sizes.

Small and narrow plantations associated with closer direct vicinity to complex vegetation habitat can be effectively colonized by natural enemies, especially generalist predators (Bianchi et al., 2006; Koh, 2008b; Koh et al., 2009). Here, we investigated this hypothesis in our model and found that the border proximity effect of the small and narrow plantations highly influenced the level of predation pressure. These size and shape effects indicated that the predation pressure of the plantation nearby the field edge benefits greatly from different border types. Several studies for a number of different biocontrol agents in agricultural systems showed that the arrival time of biocontrol agents into the plantation center might be shorter in smallized arable fields due to the spillover of species to a plantation resulted the pest population only grow in small restricted area (Landis and Van der Werf, 1997; Settle et al., 1996).

In order to provide long-term pest management, the farmers are recommended to design their plantation with a high proportion of the plantation area nearby rich vegetation, either by developing plantations with small sizes or by using narrow plantation shapes and retaining more complex habitats between the plantations. The plantation management which maintains bare 
ground and less understory vegetation on the landscape shows as hostile habitat for most the biocontrol agents of oil palm pests (Donald, 2004; Foster et al., 2011; Koh, 2008b). The predation pressure of already developed plantations can also be improved by developing stimulation of biocontrol agents such as weedy-flowering plants as corridor below the crop understory. Finally, the model is generally able to simulate more complex landscape scenarios with heterogeneous border type fractions at the same time. Unfortunately, field data for parameterization of the overlapping effects of neighboring border types is lacking at the moment. However, in the future this feature might give even more insight on the effects of landscape context on the predation pressure inside plantations. 


\section{Conclusion}

Knowledge of landscape-driven stimulation of the predation pressure provides a way for a more sustainable method of biocontrol conservation in agricultural systems. The landscape contexts investigated in this study show the strongest effects of border type on the predation pressure, followed by the plantation size and shape effects. These insights are highly important for the development of pest management strategies using biocontrol conservation. These findings also suggest that the management of the landscape context should be considered in designing the plantations with regard to sustainable and eco-friendly plantations in the future. As the predation pressure rapidly declines when the plantation expands to bigger sizes, we recommend to the farmer to develop corridors of weedy-flowering plants inside the plantation which might help to distribute high predation pressure in the plantation, especially in large plantation. Once field data on the interacting effects of neighboring border types will be available, further research of the model study can investigate plantations with mixed border types, but which will further expand our knowledge on the effects of landscape context.

\section{Acknowledgments}

This study was financed by the Deutsche Forschungsgemeinschaft (DFG) in the framework of the collaborative German - Indonesian research project Collaborative Research Centre 990 EFForTS: Ecological and Socioeconomic Functions of Tropical Lowland Rainforest Transformation Systems (Sumatra, Indonesia). Fuad Nurdiansyah was supported by the German Academic Exchange Service (DAAD). 


\section{Reference List}

Bakeri, S.A., Ali, S.R.A., Tajuddin, N.S., Kamaruzzaman, N.E., 2009. Efficacy of entomopathogenic fungi, Paecilomyces spp., in controlling the oil palm bagworm, Pteroma pendula (Joannis). J. Oil Palm Res. 21, 693-699.

Barbosa, P. (Ed.), 1998. Conservation biological control. Academic Press, San Diego.

Basri, M.W., Norman, K., Hamdan, A.B., 1995. Natural enemies of the bagworm, Metisa plana Walker (Lepidoptera: Psychidae) and their impact on host population regulation. Crop Prot. 14, 637-645. doi:10.1016/0261-2194(95)00053-4

Bianchi, F.J.J.., Booij, C.J.., Tscharntke, T., 2006. Sustainable pest regulation in agricultural landscapes: a review on landscape composition, biodiversity and natural pest control. Proc. R. Soc. B Biol. Sci. 273, 1715-1727. doi:10.1098/rspb.2006.3530

Chung, A.Y.C., Eggleton, P., Speight, M.R., Hammond, P.M., Chey, V.K., 2000. The diversity of beetle assemblages in different habitat types in Sabah, Malaysia. Bull. Entomol. Res. 90, 475-496.

Donald, P.F., 2004. Biodiversity impacts of some agricultural commodity production systems. Conserv. Biol. 18, 17-37. doi:10.1111/j.1523-1739.2004.01803.x

Denmead Lisa H., Bernhard Klarner, Ingo Grass, Yann Clough, Valentyna Krashevska, Widria Liza, Akhmad Rizali, Stefan Scheu, Rahayu Widyastuti, Teja Tscharntke, Ants affect belowground invertebrate communities and associated ecosystem processes across tropical land-use systems (in prep.)

Dislich, C., C. Keyel, A., Salecker, J., Kisel, Y., M. Meyer, K., D. Corre, M., Faust, H., Hess, B., Knohl, A., Kreft, H., Meijide, A., Nurdiansyah, F., Otten, F., Pe’er, G., Steinebach, S., Tarigan, S., Tscharntke, T., Tölle, M., Wiegand, K., in revision. Ecosystem functions of oil palm plantations: a review. Biol. Rev.

FAOSTAT [WWW Document], 2016. URL http://faostat.fao.org/site/339/default.aspx (accessed 2.15.16).

Fayle, T.M., Turner, E.C., Foster, W.A., 2013. Ant mosaics occur in SE Asian oil palm plantation but not rain forest and are influenced by the presence of nest-sites and nonnative species. Ecography 36, 1051-1057. doi:10.1111/j.1600-0587.2012.00192.x

Fitzherbert, E., Struebig, M., Morel, A., Danielsen, F., Bruhl, C., Donald, P., Phalan, B., 2008. How will oil palm expansion affect biodiversity? Trends Ecol. Evol. 23, 538-545. doi:10.1016/j.tree.2008.06.012

Foster, W.A., Snaddon, J.L., Turner, E.C., Fayle, T.M., Cockerill, T.D., Ellwood, M.D.F., Broad, G.R., Chung, A.Y.C., Eggleton, P., Khen, C.V., Yusah, K.M., 2011. Establishing the evidence base for maintaining biodiversity and ecosystem function in the oil palm landscapes of South East Asia. Philos. Trans. R. Soc. B Biol. Sci. 366, 3277-3291. doi:10.1098/rstb.2011.0041

Gray, C.L., Lewis, O.T., 2014. Do riparian forest fragments provide ecosystem services or disservices in surrounding oil palm plantations? Basic Appl. Ecol. 15, 693-700. doi:10.1016/j.baae.2014.09.009

Hajek, A.E., 2004. Natural Enemies: An Introduction to Biological Control. Cambridge University Press.

Kamarudin, N., Wahid, M.B., 2010. Interactions of the bagworm, Pteroma pendula (Lepidoptera: Psychidae), and its natural enemies in an oil palm plantation in Perak. J. Oil Palm Res. 22, 758-764. 
Koh, L.P., 2008a. Can oil palm plantations be made more hospitable for forest butterflies and birds? J. Appl. Ecol. 45, 1002-1009. doi:10.1111/j.1365-2664.2008.01491.x

Koh, L.P., 2008b. Birds defend oil palms from herbivorous insects. Ecol. Appl. 18, 821-825. doi:10.1890/07-1650.1

Koh, L.P., Ghazoul, J., 2008. Biofuels, biodiversity, and people: Understanding the conflicts and finding opportunities. Biol. Conserv. 141, 2450-2460. doi:10.1016/j.biocon.2008.08.005

Koh, L.P., Levang, P., Ghazoul, J., 2009. Designer landscapes for sustainable biofuels. Trends Ecol. Evol. 24, 431-438. doi:10.1016/j.tree.2009.03.012

Koh, L.P., Wilcove, D.S., 2007. Cashing in palm oil for conservation. Nature 448, 993-994. doi:10.1038/448993a

Landis, D.A., Van der Werf, W., 1997. Early-season predation impacts the establishment of aphids and spread of beet yellows virus in sugar beet. Entomophaga 42, 499-516.

Lucey, J.M., Hill, J.K., 2012. Spillover of Insects from Rain Forest into Adjacent Oil Palm Plantations. Biotropica 44, 368-377. doi:10.1111/j.1744-7429.2011.00824.x

Luke, S.H., Fayle, T.M., Eggleton, P., Turner, E.C., Davies, R.G., 2014. Functional structure of ant and termite assemblages in old growth forest, logged forest and oil palm plantation in Malaysian Borneo. Biodivers. Conserv. 23, 2817-2832. doi:10.1007/s10531-014-0750-2

McCarthy, J., Zen, Z., 2010. Regulating the Oil Palm Boom: Assessing the Effectiveness of Environmental Governance Approaches to Agro-industrial Pollution in Indonesia. Law Policy 32, 153-179.

Norris, R.F., Caswell-Chen, E.P., Kogan, M., 2003. Concepts in Integrated Pest Management. Prentice Hall.

Obidzinski, K., Andriani, R., Komarudin, H., Andrianto, A., 2012. Environmental and Social Impacts of Oil Palm Plantations and their Implications for Biofuel Production in Indonesia. Ecol. Soc. 17. doi:10.5751/ES-04775-170125

Pfeiffer, M., Cheng Tuck, H., Chong Lay, T., 2008. Exploring arboreal ant community composition and co-occurrence patterns in plantations of oil palm Elaeis guineensis in Borneo and Peninsular Malaysia. Ecography 31, 21-32. doi:10.1111/j.2007.09067590.05172.X

Phalan, B., Bertzky, M., Butchart, S.H.M., Donald, P.F., Scharlemann, J.P.W., Stattersfield, A.J., Balmford, A., 2013. Crop Expansion and Conservation Priorities in Tropical Countries. PLoS ONE 8, e51759. doi:10.1371/journal.pone.0051759

Savilaakso, S., Garcia, C., Garcia-Ulloa, J., Ghazoul, J., Groom, M., Guariguata, M.R., Laumonier, Y., Nasi, R., Petrokofsky, G., Snaddon, J., Zrust, M., 2014. Systematic review of effects on biodiversity from oil palm production. Environ. Evid. 3, 1-21. doi:10.1186/2047-2382-3-4

Seifert, C.L., Schulze, C.H., Dreschke, T.C.T., Frötscher, H., Fiedler, K., 2016. Day vs. night predation on artificial caterpillars in primary rainforest habitats - an experimental approach. Entomol. Exp. Appl. 158, 54-59. doi:10.1111/eea.12379

Senior, M.J.M., Hamer, K.C., Bottrell, S., Edwards, D.P., Fayle, T.M., Lucey, J.M., Mayhew, P.J., Newton, R., Peh, K.S.-H., Sheldon, F.H., Stewart, C., Styring, A.R., Thom, M.D.F., Woodcock, P., Hill, J.K., 2013. Trait-dependent declines of species following conversion of rain forest to oil palm plantations. Biodivers. Conserv. 22, 253-268.

doi:10.1007/s10531-012-0419-7 
Settle, W.H., Ariawan, H., Astuti, E.T., Cahyana, W., Hakim, A.L., Hindayana, D., Lestari, A.S., 1996. Managing Tropical Rice Pests Through Conservation of Generalist Natural Enemies and Alternative Prey. Ecology 77, 1975. doi:10.2307/2265694

Tscharntke, T., Bommarco, R., Clough, Y., Crist, T.O., Kleijn, D., Rand, T.A., Tylianakis, J.M., van Nouhuys, S., Vidal, S., 2007. Conservation biological control and enemy diversity on a landscape scale. Biol. Control 43, 294-309. doi:10.1016/j.biocontrol.2007.08.006

Tscharntke, T., Klein, A.M., Kruess, A., Steffan-Dewenter, I., Thies, C., 2005. Landscape perspectives on agricultural intensification and biodiversity - ecosystem service management. Ecol. Lett. 8, 857-874. doi:10.1111/j.1461-0248.2005.00782.x

Turner, E.C., Snaddon, J.L., Fayle, T.M., Foster, W.A., 2008. Oil Palm Research in Context: Identifying the Need for Biodiversity Assessment. PLoS ONE 3, e1572. doi:10.1371/journal.pone.0001572

Tvardikova, K., Novotny, V., 2012. Predation on exposed and leaf-rolling artificial caterpillars in tropical forests of Papua New Guinea. J. Trop. Ecol. 28, 331-341. doi:10.1017/S0266467412000235

Way, M.J., Khoo, K.C., 1992. Role of ants in pest management. Annu. Rev. Entomol. 37, 479503.

Wood, B.J., 2002. Pest control in Malaysia's perennial crops: a half century perspective tracking the pathway to integrated pest management. Integr. Pest Manag. Rev. 7, 173-190.

Zeddam, J.L., Cruzado, J.A., Rodriguez, J.L., Ravallec, M., 2003. A new nucleopolyhedrovirus from the oil-palm leaf-eater Euprosterna elaeasa (Lepidoptera : Limacodidae): preliminary characterization and field assessment in Peruvian plantation. Agric. Ecosyst. Environ. 96, 69-75. doi:10.1016/S0167-8809(03)00034-3

Zurell, D., Berger, U., Cabral, J.S., Jeltsch, F., Meynard, C.N., Münkemüller, T., Nehrbass, N., Pagel, J., Reineking, B., Schröder, B., Grimm, V., 2010. The virtual ecologist approach: simulating data and observers. Oikos 119, 622-635. doi:10.1111/j.1600-

0706.2009.18284.x 


\section{SUMMARY}

Oil palm is the highest yielding vegetable oil crop per unit area and plantations expand at a rapid pace. Large-scale expansion of oil palm plantations, transformed from natural habitat, results in huge biodiversity losses. Hence, balancing crop production with conserving biodiversity is a topical scientific and political challenge. Biodiversity loss affects ecosystem services such as pest control, pollination and soil processes. More detailed research might draw the farmers’ attention to the reduction of these ecosystem functions, which may directly affect their income and their plantations’ sustainability. Oil palm plantations suffer from pests and diseases, but current management practices have negative impacts on biodiversity, and the biocontrol of the pests and diseases. Factors hypothesized to influence the occurrence of pests, diseases, and biocontrol in oil palm plantations can be grouped as follows: pesticides usage, fertilizer application, vegetation surrounding oil palm plantations, and oil palm understory. A prominent recommendation for increasing native biocontrol agents in the plantations is to increase landscape heterogeneity and connectivity through practices allowing for patches of natural habitats within the landscape and understorey vegetation. Research on the factors influencing biocontrol agents in oil palm plantations is lacking but urgently needed to understand the potential for the application of conservation biological control.

In this thesis, we present a review of the pests, diseases and biocontrol in oil palm plantations, the influence of management practices and recommendations for developing sustainable pest and disease management through conservation biological control. We systematically reviewed the literature using the ISI Web of Science, Ebscohost and Google Scholar. In addition, we investigated the effects of six types of boundaries of oil palm plantations 
(another oil palm plantation (control), weedy oil palm, weedy rubber, scrub, jungle rubber, and secondary forest) and the distance from the adjacent boundary vegetation on predation of oil palm caterpillar pests. This field study was conducted in two regions in the Batanghari and Sarolangun Regencies in Jambi Province, Sumatra, Indonesia. Finally, by using agent-based models (NetLogo), we extend the previous study on the enhancement of predation by adjacent vegetation by simulating the role of border type, plantation size and plantation shape.

In the review, we found trunk borer pests, leaf defoliator pests and wilt diseases to be the most studied organisms in oil palm. Studies on pest and disease biocontrol have, in the past, mostly focused on the introduction of exotic biocontrol agents to the field or the assessment of potential agents, rather than evaluating factors influencing the native enemy populations. Although biocontrol could effectively and efficiently regulate pests and diseases, most practical suggestions are impracticable to be applied in big plantatios due to affordability and also sustainability of the controls. Whilst direct studies on the effects of the local and landscape managements on pests, diseases and biocontrol are missing, information from published studies can be used to estimate the relative important of management type. For instance, pesticide applications tend to produce problems such as damage on non-target organisms and pest resistance. Systemic insecticides, known as an efficient control method for pests and diseases, show irregular results in term of effectiveness and efficiency. Fertilizer applications can significantly increase or decrease the incidence of diseases, depending on the type of soil. Fertilizer application accompanied with burying oil-palm waste as compost around oil palms, and together with Trichoderma spp., appears to be the best method for promoting biocontrol of diseases. Studies on vegetation surrounding oil palm plantations focus on butterflies and wild pigs, whereas pest, disease, and biocontrol organisms have not been studied yet. Oil palm 
understory has a positive influence, but more likely if specific flowering plants, e.g. Cassia cobanensis and Asystasia gangetica, and other plants such as Nephrolepsis biserrata, Pueraria phaseoloides, Calopogonium caeruleum and Arachis pintoi are grown to protect the crop from pest and disease developments or as food sources for biocontrol agents.

The field investigation revealed that ants and bush crickets were the most prominent predators of caterpillar pest in the plantations, whereas birds, bats, monkeys, beetles, and mollusks played a minor role. Predation rates were $\sim 70 \%$ higher in non-oil palm habitat. This effect spilled over into the oil palm plantations, where predations were increased by $55-100 \%$ at a distance of $20 \mathrm{~m}$ from the border and $40-55 \%$ at a distance of $50 \mathrm{~m}$ from the border. Hence, predation rates in oil palm decreased slightly but significantly with distance to the border, indicating the need for improved vegetation diversification inside plantations.

Further tests with simulation models show that complex vegetation surrounding the plantation can enhance pest predation levels, even doubling predation rates inside the plantation. Increasing plantation size led to considerable decrease in pest predation, while changing the plantation geometry in a way that perimeter-area ratios increase can compensate the loss of predation by ca. $20 \%$. The effect of the landscape context was limited to plantation sizes between 50 - 100 ha, suggesting higher potential pest attacks in plantations larger than 100ha.

In conclusion, there is a lack of research how pests, diseases and biocontrol are determined by local management. Further, we recommend a broader perspective, considering also landscape management and its potential for biocontrol conservation in future studies. Success of sustainable pest and disease managements through conservation biological control should include significant reductions in pesticide applications, the use of antagonists such as 
Trichoderma spp. in the composts or fertilizers, maintenance or restoration of complex vegetation surrounding plantations, allowing weedy and flowering plant strips to grow as corridor inside the plantation, and limiting plantation size to small or mid scales and long edges with nearby complex vegetation boundaries. 


\section{ACKNOWLEDGMENT}

I would like to express my appreciation and respect to Prof. Dr. Teja Tscharntke, Prof. Dr. Kerstin Wiegand and Dr. Yann Clough for their supports during my PhD study. I am very thankful for the opportunity and warm welcome in their groups which opened the access for me to the key important resources and skills of my academic and research curiosities. In their groups, I could interact with many students and scientists from diverse professional and multicultural background form all over the world. During my study, they continuously supported me in many problematic situations including academic administration, scholarship funding and also social life as overseas student. I learned a lot from them how to be a professional scientist and to follow an academic career. Among offering flexibility and freedom to decide my own research questions, they were still able to shape and frame my research perspectives which I think it is one of the strengths of their supervision. Thus, I was really glad to interact with them during my study and I certainly encourage other people or students to have and feel the same experience.

I sincerely thank Jann Salecker, MS.c, Dr. Lisa Deanmead, Dr. Johannes Heinonen, and Dr. Kevin Darras for their help, support, effort, and patience during the project and manuscript development. I learned many things from them which really enriched my knowledge and experiences in the science world. I am very thankful to Dr. David Perovic who also has helped me a lot with my language limitation in the beginning of the study, especially in academic writing. Thanks also to Davig Warisman, SP, Deslian Dwi Permana, SP, Febrina Herawani, SP, Tutty, SP, Rico Fardiansyah , SP, Derly Hartika, SP for their support during field and laboratory work in Jambi, Indonesia. They made all of the work required to seem really easy and did it very well. Thanks also go to the staff of the Collaborative Research Centre 990 EFForTS in Jambi, especially Dr. Bambang Irawan and the staff managing the administration and transportation 
during the field work. I thank the village leaders and local smallholders for granting us the use of their properties. I am thankful to the German Academic Exchange Service (DAAD) for the finance support during staying in Germany and the Deutsche Forschungsgemeinschaft (DFG) in the framework of the collaborative German - Indonesian research project Collaborative Research Centre 990 EFForTS for the research study costs.

I would like to thank my colleagues in the Agroecology group for their support, help and the many unforgettable times in Göttingen. Especially to Hagen Andert, my close German friend, I do really appreciate on what you have done, sharing a lot of German stories, cultures, preferences, hobby, and values. Thus, I have better understanding why most people said German people are so interesting, friendly and kindness people, and not only hard workers and serious people. Thanks to Jutta Gilles, Susanne Jahn and Brigitte Jünemann for their administration supports in the Agroecology group. I thank many Indonesian families in Göttingen, both members of PPI Göttingen and KALAM, for their friendship and family sense.

I deeply thank my wife, Agnesi Silvana, and my son, Zuwie Marsa Tawadhu, who always support, whish, and accompany me from the beginning to the end of my study. Finally, I would like to dedicate this work to my father Drs. Fauzi RH. MS and mother Nelly Herawaty, who have taught me about life, especially to my father who passed away just before I was selected as one of the German Scholarship holders (DAAD). Actually, this achievement is his big dream for his children where he wanted us to pass his previous success as a university lecturer with master degree. 


\section{LIST OF PUBLICATIONS}

Nurdiansyah Fuad, Sri Mulyati, and Nezrietty, 2011. Pelatihan dan Implementasi Sistem Pengendalian Hama Terpadu (PHT) Penyakit Jamur Akar Putih (JAP) di Desa Sungai Buluh Kabupaten Batang Hari. Laporan Hasil Ipteks Bagi Masyarakat. Direktorat Penelitian dan Pengabdian kepada Masyarakat. Kementerian Riset Teknologi dan Pendidikan Tinggi Republik Indonesia.

Wilyus, Asni Johan and Fuad Nurdiansyah, 2011. Teknik Pengendalian Hayati Penggerek Batang Padi (Pbp) Dengan Pemanfaatan Parasitoid Telur. Laporan Hasil Penelitian Hibah Bersaing. Direktorat Penelitian dan Pengabdian kepada Masyarakat. Kementerian Riset Teknologi dan Pendidikan Tinggi Republik Indonesia.

Dislich Claudia, Alexander C. Keyel, Jan Salecker, Yael Kisel, Katrin M. Meyer, Mark Auliya, Andrew D. Barnes, Marife D. Corre, Kevin Darras, Heiko Faust, Bastian Hess Alexander Knohl, Holger Kreft, Ana Meijide, Fuad Nurdiansyah, Fenna Otten, Guy Pe’er, Stefanie Steinebach, Suria Tarigan, Merja H. Tölle, Teja Tscharntke, and Kerstin Wiegand, (In review). Ecosystem functions of oil palm plantations compared to forests: a review. Biological Reviews Journal.

Denmead Lisa H., Kevin Darras, Yann Clough, Patrick Diaz, Ingo Grass, Munir P. Hoffmann, Fuad Nurdiansyah, and Teja Tscharntke, (In review). The role of ants, birds and bats for ecosystem functions and services in oil palm plantations. Proceedings of the Royal Society B.

Nurdiansyah, Fuad, Yann Clough, Kerstin Wiegand, and Teja Tscharntke (Preparation). Local and landscape management effects on pests, diseases and biocontrols in oil palm plantations - a review. Agriculture, Ecosystems and Environment - Elsevier.

Nurdiansyah Fuad, Lisa H. Denmead, Yann Clough, Kerstin Wiegand, and Teja Tscharntke (In revision). Biological control in oil palm enhanced by landscape context. Agriculture, Ecosystems and Environment - Elsevier.

Nurdiansyah Fuad, Jan Salecker, Johannes Heinonen, Yann Clough, Teja Tscharntke, and Kerstin Wiegand (Preparation). Landscape context of oil palm plantations affects biocontrol pressure: a model. Agriculture, Ecosystems and Environment - Elsevier. 


\section{CURRICULUM VITAE}

PERSONAL INFORMATION

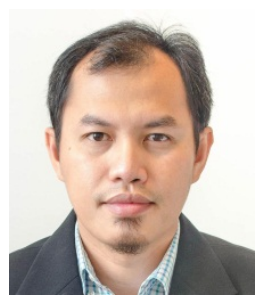

Fuad Nurdiansyah

- Jl. H. Ibrahim, Lrg. Radio RT/RW. 21/03 No. 31 Kel. Rawasari Kec. Kota Baru, Jambi, Indonesia Kode Pos, 36125

$+6208127475453$

fuad.nurdiansyah@gmail.com

Sex Male | Date of birth 12.12.1981 | Nationality Indonesian
WORK EXPERIENCE

01/2005-Present
Lecturer in Agroecotechnology

Jambi University

Kampus Pinang Masak, Jln. Raya Jambi Muara-Bulian, Mendalo Darat Km. 15 Jambi, 36361 Jambi (Indonesia), http://webunja.unja.ac.id/

Teaching, Research and Community Service

Business or sector Education

PhD Student in Agroecology (IPAG Program)

EQF level 8

Agroecology Group, Department of Crop Science in Georg-August-University Göttingen, Goettingen (Germany)

Modelling Ecosystem with C++ , Scientific Writing and Publishing in Crop Sciences, Agents-based Modeling for Processes and Dynamics in Landscape Geography, Manuscript Seminar, Linear Statistical Models with R, Systematic Review and MetaAnalysis in Ecology, and Dissertation Title: "Sustainable Management of Oil Palm Plantation for Pest and Disease Controls”

\section{1/2008-12/2009 Master of Plant Health and Biosecurity}

EQF level 7

The University of Adelaide (Waite Campus)

Waite Rd, Urrbrae, SA, 5064 Adelaide (Australia)

Plant Protection (Pest, Disease and Weed), Biological Control, Integrated Pest Management, Biosecurity, Management and Regulation in Plant Health, Pest Control; Weeds Management, and Thesis Title : "Potential Geographical Distribution of Micromus tasmaniae Walker (Neuroptera: Hemerobiidae); The Importance of Temperature-Dependent Development"

\section{7/1999-10/2004 Bachelor of Agriculture} EQF level 6 Jambi University

Km. 15 Raya Jambi-Muara Bulian rd, Mendalo Darat, 36361 Jambi (Indonesia) 
Plant Protection, Pest Management; Regulation in Plant Health; Experimental Design, Several Fundamental Subjects (e.g. Biology, Chemistry, Mathematics), and Thesis Title: "Evaluation of Integrated Pest Management of Fusarium Wilt in Muaro Jambi Regency, Jambi Province".

PERSONAL SKILLS

Mother tongue(s)

Other language(s)

English

German

Communication skills

Digital competence

\begin{tabular}{|c|c|c|c|c|}
\hline \multicolumn{5}{|c|}{ SELF-ASSESSMENT } \\
\hline $\begin{array}{c}\text { Information } \\
\text { processing }\end{array}$ & Communication & $\begin{array}{c}\text { Content } \\
\text { creation }\end{array}$ & Safety & $\begin{array}{c}\text { Problem } \\
\text { solving }\end{array}$ \\
\hline Proficient user & Proficient user & $\begin{array}{c}\text { Independent } \\
\text { user }\end{array}$ & $\begin{array}{c}\text { Proficient } \\
\text { user }\end{array}$ & $\begin{array}{c}\text { Independent } \\
\text { user }\end{array}$ \\
\hline
\end{tabular}

Digital competences - Self-assessment grid

Competent with most Microsoft Office programmes, academic softwares that are Zotero, Embarcadero C++, NetLogo, R software, GenStat, and some experience with graphic design programmes such as Photoshop, Lightroom, Corel Draw and Autodesk 3ds Max.

Other skills Personal interests, I like to stay up-to-date and connect with design community. Enjoy all sports particularly badminton, soccer and swimming. I enjoy to travel and experience different cultures 